\title{
$\mathrm{UiO}$ : Det juridiske fakultet
}

\section{Tilbakesøkning ved feilbetaling}

Kandidatnummer: 224

Leveringsfrist: 1. juni 2018

Antall ord: 39906 


\section{Innholdsfortegnelse}

1 INNLEDNING ..................................................................................................... 1

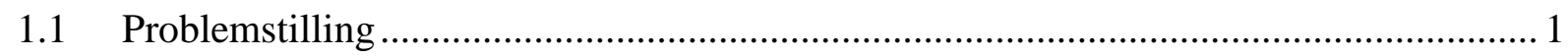

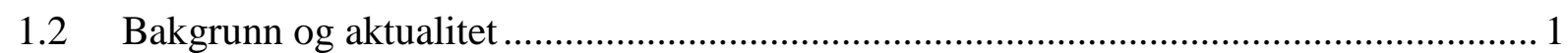

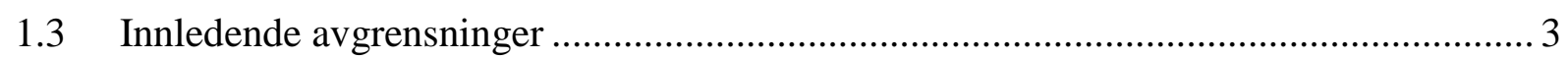

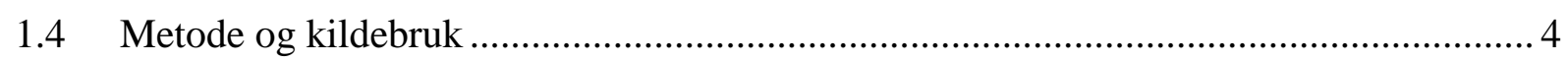

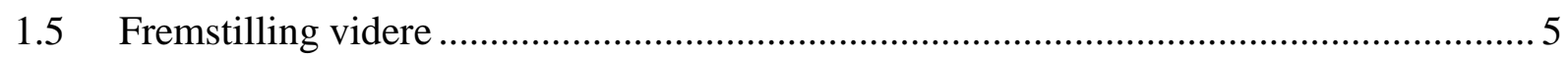

2 LEREN OM CONDICTIO INDEBITI I NORSK RETT ................................... 7

2.1 Tradisjonell forståelse av condictio indebiti ............................................................. 7

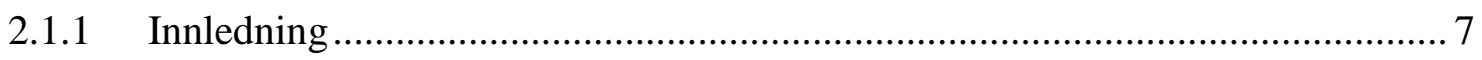

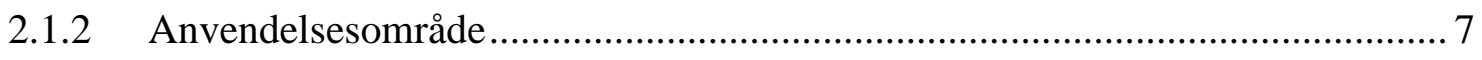

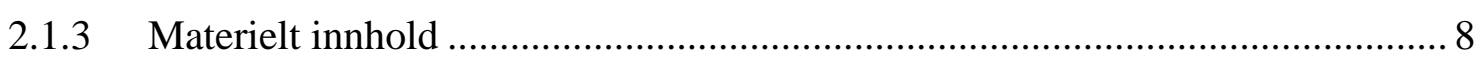

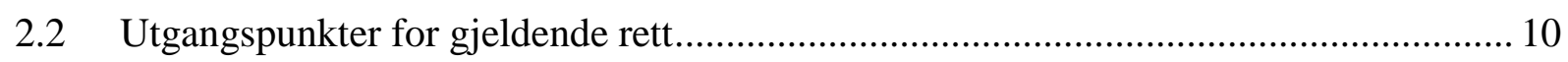

2.2.1 Rettslig grunnlag for forpliktelse................................................................ 10

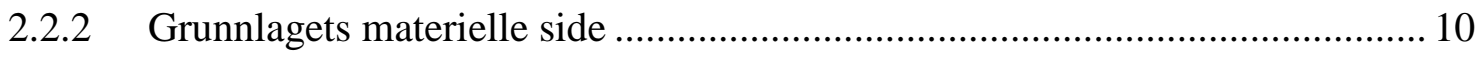

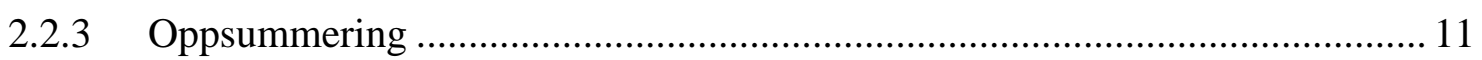

3 PRESISERINGER OG RETTSLIG PLASSERING ............................................ 12

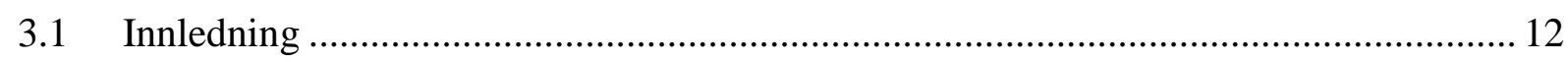

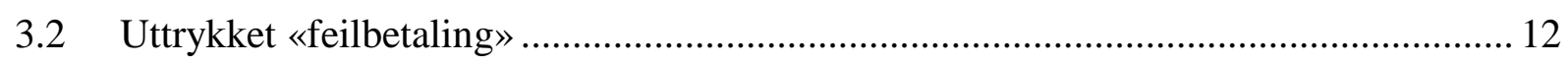

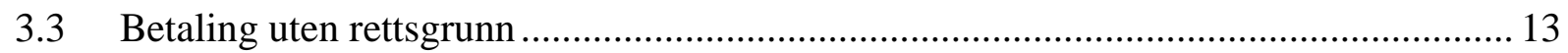

3.4 Avgrensning mot andre typer betaling uten rettsgrunn........................................ 14

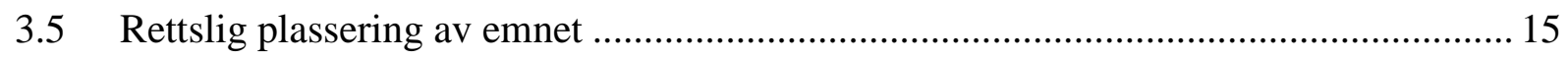

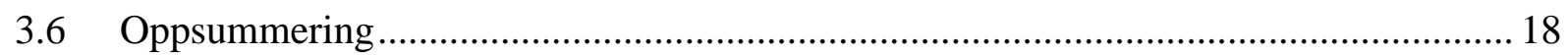

4 GRUNNVILKÅR FOR TILBAKESØKNING ...................................................... 19

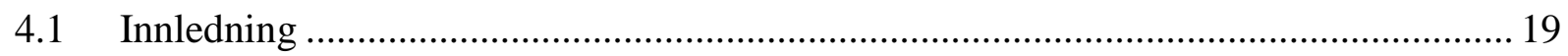

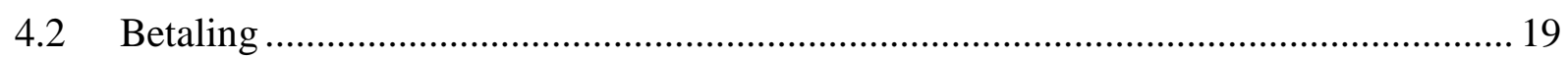

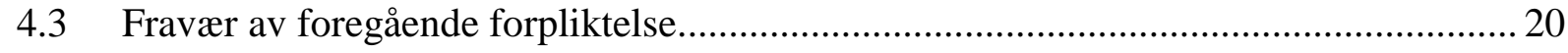

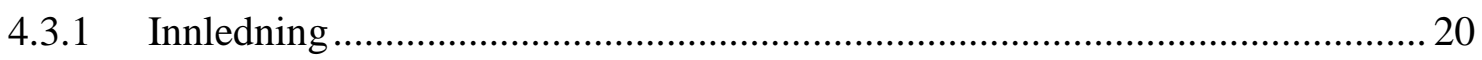

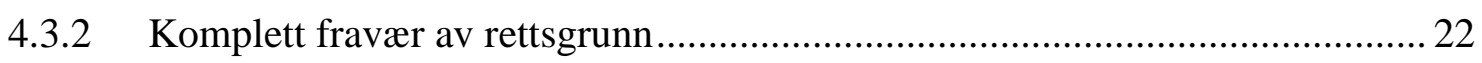

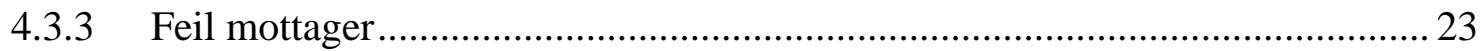

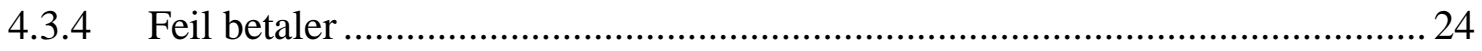

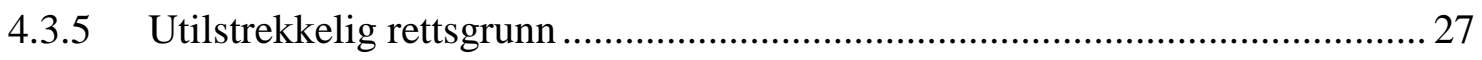

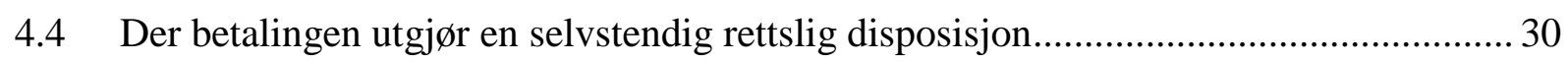

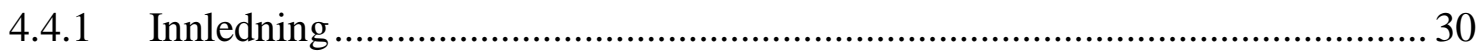




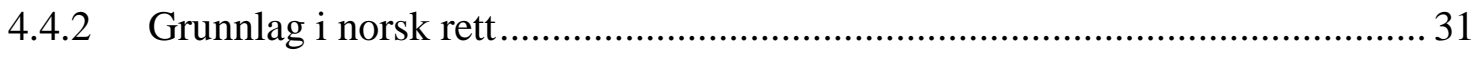

4.4.3 I hvilke tilfeller utgjør betalingen en rettslig disposisjon? .............................. 34

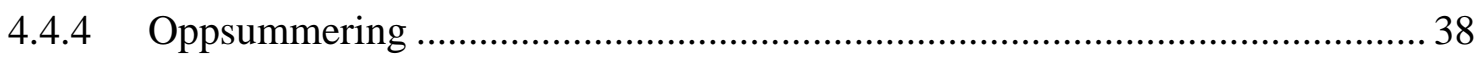

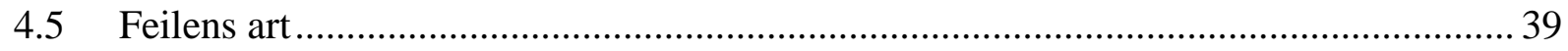

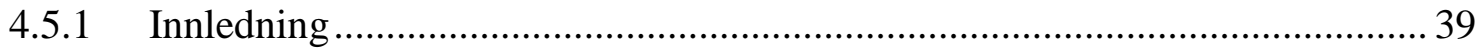

4.5.2 Villfarelse om forpliktelsens eksistens og omfang ........................................ 39

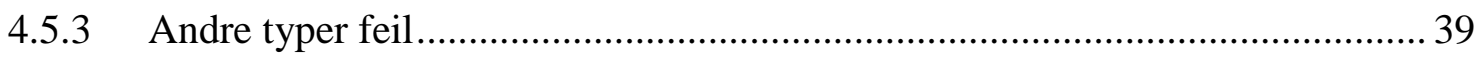

4.5.4 Handlinger som vanskelig kan sies å bero på en feil...................................... 40

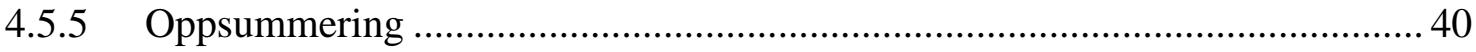

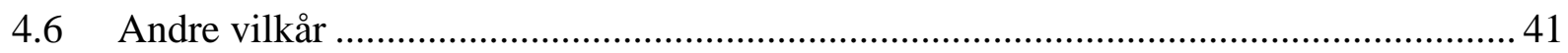

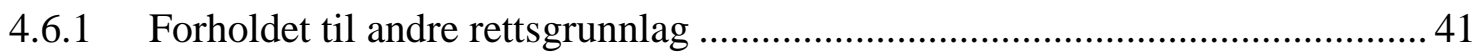

4.6.2 Krav mellom andre enn betaler og mottager ............................................. 42

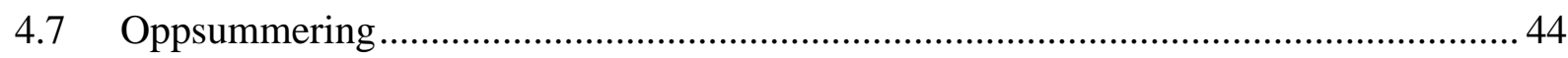

5 TILFELLER SOM KAN AVGJØRES UTEN HELHETSVURDERING ............. 46

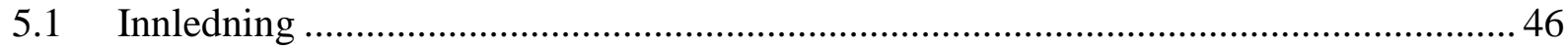

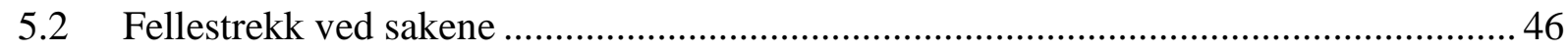

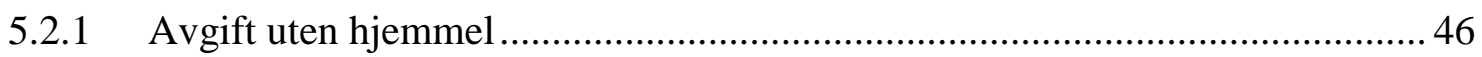

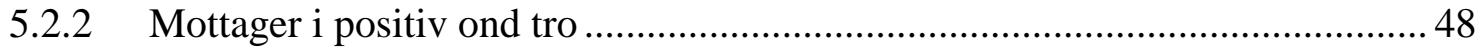

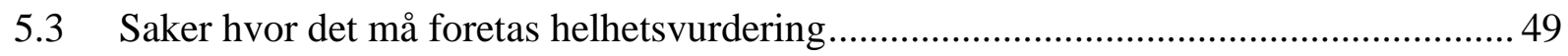

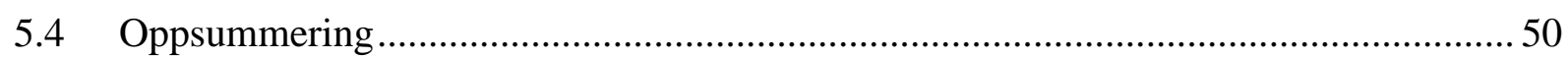

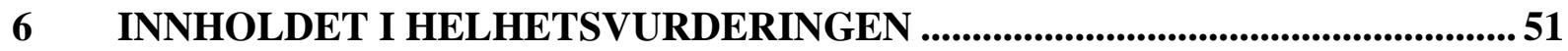

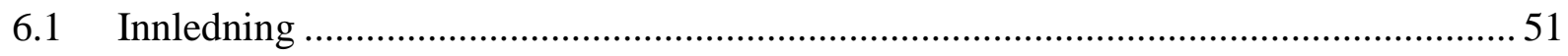

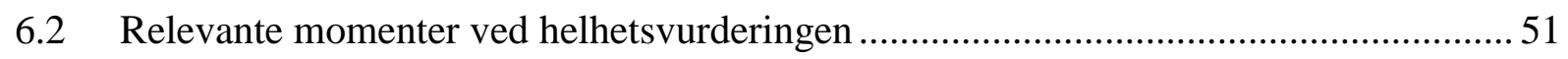

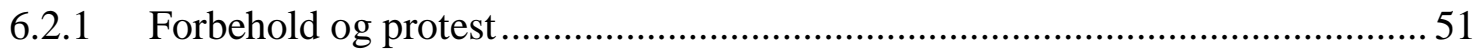

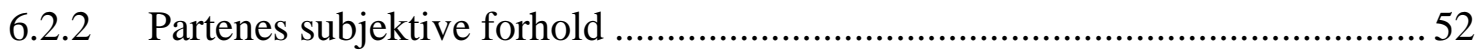

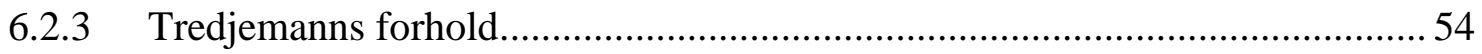

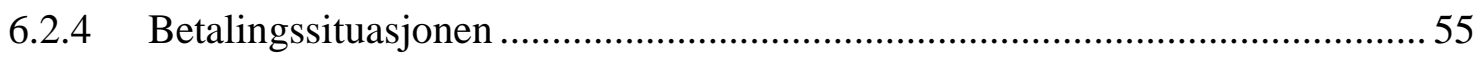

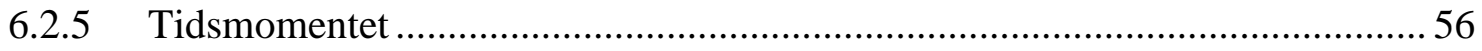

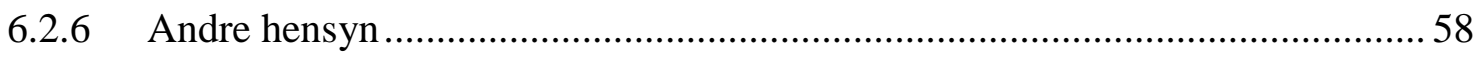

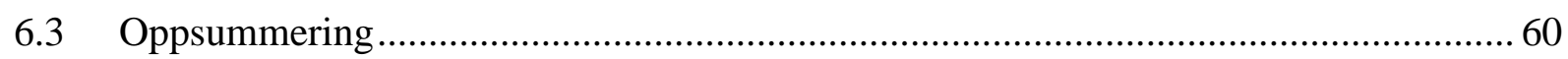

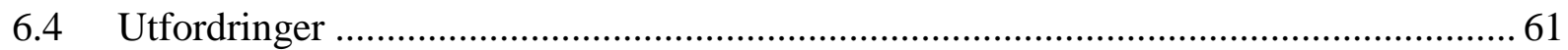

7 BETRAKTNINGER RUNDT HELHETSVURDERINGEN.................................62

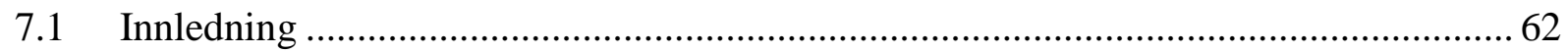

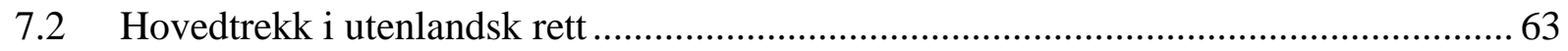

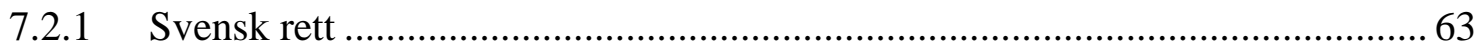

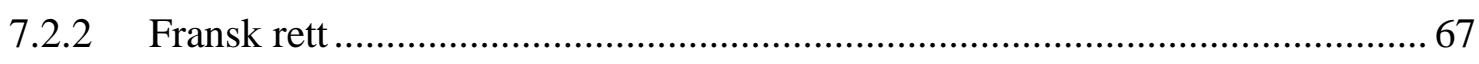




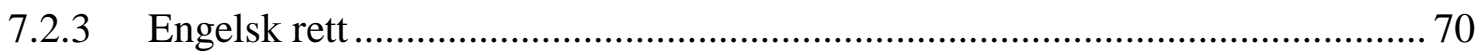

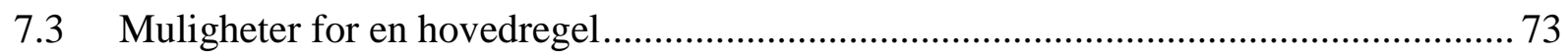

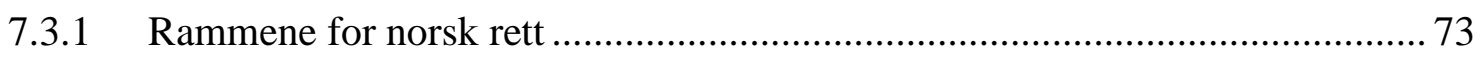

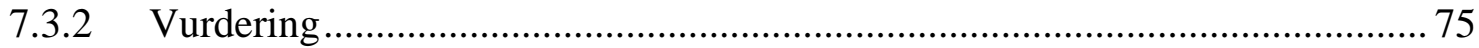

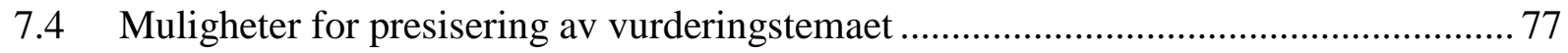

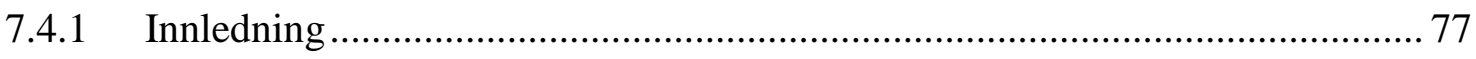

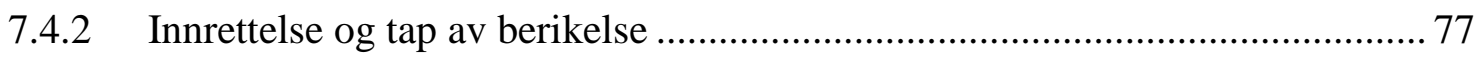

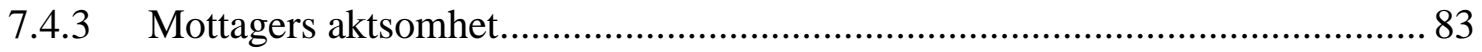

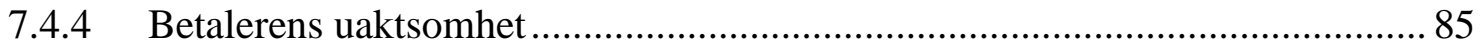

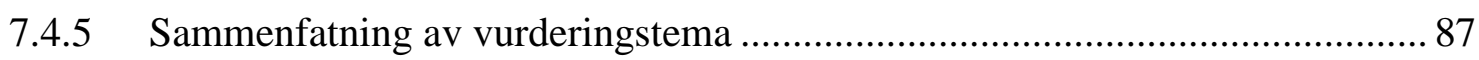

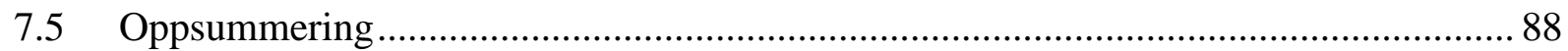

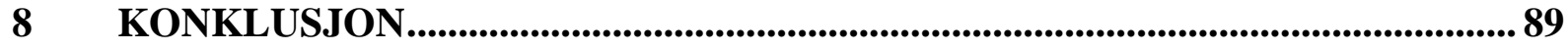

9 AVSLUTTENDE NORMATIVE BETRAKTNINGER ..........................................91

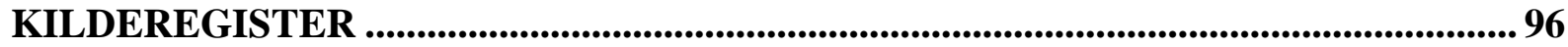




\subsection{Problemstilling}

Temaet for avhandlingen er tilbakesøkning der man har betalt noe man ikke skyldte. Betalingen skyldes en feil, og spørsmålet er når man ved slike feilbetalinger kan ha krav på å få pengene tilbake. Med tilbakesøkning sikter jeg her til de tilfeller hvor kravet om å få det uriktig betalte tilbake, ikke bygger på kontrakt eller erstatningsbetingende forhold. Spørsmålet er altså i hvilke tilfeller feilbetalingen i seg selv gir krav på å få tilbakebetaling.

Avhandlingen har to problemstillinger: For det første vil jeg undersøke hvilke grunnvilkår som må vere oppfylt for at Høyesterett skal ta stilling til et krav om tilbakesøkning i feilbetalingstilfellene. For det annet vil jeg undersøke hvordan Høyesterett konkret argumenterer når de tar stilling til om et tilbakesøkningskrav skal føre frem eller ikke.

Det finnes i norsk rett flere ulovfestede grunnlag for tilbakes $\varnothing$ kning der man har ytet noe man ikke var forpliktet til, samt enkelte lovfestede særreguleringer. Denne avhandlingen tar for seg tilfellene hvor det er betalt på grunn av en eller annen form for feil. I norsk rett har man i slike tilfeller ofte vist til den ulovfestede laren om condictio indebiti. Enkelt sagt er den tradisjonelle tilnærmingen til tilbakesøkning ved feilbetalinger todelt: Man må først finne ut om «læren» kommer til anvendelse og deretter foreta en konkret helhetsvurdering av hvorvidt tilbakesøkning er rimelig. Hvilke betingelser som må foreligge for at «læren» skal komme til anvendelse, og hva som skal vektlegges i den konkrete vurderingen, er imidlertid uklart. Også Høyesterett har flere ganger uttalt at «læren» er et fleksibelt verktøy.

Målet med denne avhandlingen er ikke å fastlegge innholdet i en slik fleksibel lære. I alle fall deler av læren om condictio indebiti slik den benyttes i norsk rett, må anses som en rettslig standard, og for en slik standard kan man ikke fullt ut fastlegge «gjeldende rett». Det jeg ønsker å oppnå med denne avhandlingen, er derimot å belyse ulike spørsmål knyttet til ulovfestet tilbakes $ø$ kning og gi et bidrag til hvordan man kan argumentere, og hvordan man kan forstå og systematisere stoffet på en hensiktsmessig måte. Utgangspunktet vil være rettspraksis som materielt sett gjelder tilbakesøkning av feilbetalinger, enten man har brukt uttrykket condictio indebiti eller ikke. For å belyse spørsmålet vil jeg også se til andre kilder for argumenter for gode løsninger, slik som spesiallovgivning, uttalelser fra sivilombudsmannen, litteratur og utenlandsk rett.

\section{$1.2 \quad$ Bakgrunn og aktualitet}

I norsk rett har man for den typen rettsspørsmål avhandlingen omhandler, som nevnt ofte tatt utgangspunkt i læren om condictio indebiti som grunnlag for tilbakesøkningskrav. Tradisjonelt sett har man bygget på at læren kommer til anvendelse der det har skjedd en ytelse, uten 
at det forelå en rettslig betalingsforpliktelse, men hvor betaleren har vært i en villfarelse om at slik plikt forelå. ${ }^{1}$ Dersom disse betingelsene forelå, måtte man i tillegg foreta en konkret helhetsvurdering. ${ }^{2}$ På bakgrunn av denne helhetsvurderingen måtte domstolene avgjøre hvorvidt det var rimelig om den som hadde mottatt et beløp med urette, skulle få beholde beløpet, eller om tilbakesøkningskravet skulle føre frem slik at betaleren fikk tilbake pengene.

Det følger imidlertid av Høyesteretts praksis fra de siste tiår at de betingelser som er nevnt i forrige avsnitt, på ingen måte er absolutte. I flere tilfeller har Høyesterett uttalt at det kan være tvilsomt hvorvidt man står overfor et «condictio indebiti-tilfelle». Likevel har man vurdert rimeligheten av tilbakesøkning og kommet til at beløpet som er mottatt med urette skal tilbakeføres. ${ }^{3}$ Dette viser at tilbakesøkning i feilbetalingstilfellene etter gjeldende rett ikke begrenser seg til den tradisjonelle oppfatningen av condictio indebiti.

Der man har kommet til at læren om condictio indebiti kommer til anvendelse, er oppfatningen i norsk rett at det må foretas en konkret helhetsvurdering for å avgjøre om tilbakesøkning skal innrømmes. Problemstillingen kan illustreres ved et typisk tilfelle fra arbeidslivet. Arbeidsgiver har feilaktig utbetalt 1000 kroner for mye hver måned i lønn til en ansatt over en lengre periode. Etter to år oppdager arbeidsgiver feilen og krever tilbake 24.000 kroner fra arbeidstageren. Arbeidsgiver har her ytet mer enn han var forpliktet til. Legger man til grunn at man står ovenfor en feilbetaling, må domstolen vurdere om det samlet sett er rimeligst at arbeidstageren får beholde pengene, eller om de skal tilbakeføres til arbeidsgiver. Arbeidstager vil kanskje argumentere med at han har mottatt pengene i god tro, og ikke kan ventes å legge merke til et så lite beløp på en vanskelig leselig lønnslipp. Videre vil han kanskje også hevde at pengene alt er forbrukt, og at det må være arbeidsgivers ansvar å se til at riktig lønn blir utbetalt. Arbeidsgiveren vil på sin side hevde at arbeidstageren ikke har noen rett til pengene, at det er denne som har ansvaret for å undersøke at lønnen er korrekt, og at han selv ikke kan bebreides særlig for feilbetalingen. Da det ikke er klare svar på problemstillingen, vil det være vanskelig å avgjøre tvisten utenfor domstolene. Fraværet av et klarere vurderingstema kan på denne måten redusere incentiver til utenomrettslige forlik.

Fraværet av rettsutvikling i retning av å presisere vurderingstemaet for helhetsdrøftelsen kan illustreres ved to uttalelser fra Høyesterett. I Rt. 1836 s. 627 uttalte Høyesterett at da det ikke fantes positiv lovgivning om spørsmålet om tilbakesøkning utenfor kontrakt, måtte dommerne være henvist til å «være forpligtede til at tage Hensyn til, hvad der efter den naturlige Billighed eller Forholdets Natur i saa Henseende kan antages at være overeensstemmende med

\footnotetext{
${ }^{1}$ Arnholm (1939) side 173.

2 Ibid. side 187.

${ }^{3}$ Se f.eks. Rt. 2010 s. 816, Rt. 2001 s. 1580 og Rt. 1998 s. 989.
} 
Lovgiverens Villie». ${ }^{4}$ Selv om uttalelsen ikke gir videre veiledning til det konkrete vurderingstemaet, viste man i 1836 i det minste til at man skulle finne frem til en løsning som kunne antas å være i overenstemmelse med lovgivers vilje. Dermed gav dette en antydning om at man burde søke å finne generelt praktiserbare regler. På denne bakgrunn er det overraskende at man nå, nesten 200 år senere, ikke har kommet lenger i å etablere generelle regler eller vurderingstemaer. Den rettssetning Høyesterett bygger på i nyere praksis, følger av Rt. 1985 s. 290 og lyder: «Det er et grunnleggende trekk i læren om condictio indebiti at hvert tilfelle skal vurderes konkret og under hensyn til rimelighet.» ${ }^{5}$ Man står altså overfor en konkret rimelighetsvurdering uten klare retningslinjer for vurderingen. Som Lilleholt treffende påpeker er ikke dette en regel, men «ein antiregel, ein regel om ikkje å ha nokon regel». ${ }^{6}$

Den siste omfattende studie av condictio indebiti ble foretatt av Arnholm i 1939. ${ }^{7}$ Siden den gang har det ikke vært gjort omfattende forsøk på å systematisere læren. Om fors $\varnothing \mathrm{k}$ på å skape mer forutberegnelighet for feilbetalingstilfellene skriver Hagstrøm at «[m]an har imidlertid her et område som vanskelig i større utstrekning kan reguleres ved faste regler uten at det i uforholdsmessig grad går ut over den konkrete rettferdighet». ${ }^{8}$ At man bør søke en praksis som er egnet til å gi et godt resultat i den konkrete sak, er et vektig hensyn. Men dette bør ikke bli en hvilepute som gjør at man ikke søker å finne nye løsninger på praktiske problemer. Det må være rettsvitenskapens oppgave å søke å finne løsninger som både kan ivareta hensynet til konkret rettferdighet og behovet for rettslig forutberegnelighet.

På denne bakgrunn mener jeg at temaet er modent for en ny gjennomgang. Ved å se hen til andre kilder enn rettspraksis, og særlig til utenlandsk rett, vil man kunne finne inspirasjon til argumenter og systematiseringer som også kan gi veiledning innen rammen av norsk rett.

\subsection{Innledende avgrensninger}

Det som skal belyses i denne avhandlingen, er fremgangsmåten ved ulovfestet tilbakesøkning. Lovfestede tilbakesøkningsregler faller i utgangspunktet utenfor, men argumenter fra spesiallovgivningen vil trekkes inn der disse kan kaste lys over generelle problemstillinger

Videre begrenser avhandlingen seg til obligatoriske krav. Tingsrettslige vindikasjonskrav, hvor «betaleren» hevder at eiendomsretten ikke er gått over, og krever tingen tilbake, faller

\footnotetext{
${ }^{4}$ Rt. 1836 s. 627 (side 628).

${ }^{5}$ Rt. 1985 s. 290 (side 294).

${ }^{6}$ Lilleholt (2017) side 497.

${ }^{7}$ Arnholm (1939) side 125 flg.

${ }^{8}$ Hagstrøm (2011) side 705.
} 
utenfor. Spørsmål knyttet til hvorvidt «betaleren» også kan ha et tinglig vindikasjonskrav i feilbetalingstilfellene, drøftes ikke.

Gjenstanden for tilbakesøkningskrav kan være både penger og ting, ${ }^{9}$ men da oppfyllelse i penger er det vanligste, vil jeg av plasshensyn begrense meg til disse tilfellene. I tilfeller hvor «ytelsen» er noe annet enn penger, men tilbakes $\emptyset$ kningskravet er et pengekrav, står man overfor et eventuelt vederlagskrav for urettmessig bruk. Disse omfattes ikke av utrykket feilbetaling i denne avhandlingen.

Ytterligere presiseringer og avgrensninger vil bli gjort i kapittel 3.

\section{$1.4 \quad$ Metode og kildebruk}

Når jeg skal undersøke det rettslige grunnlaget for tilbakesøkning ved feilbetaling, vil jeg ta utgangspunkt i den ulovfestede laren om condictio indebiti. Dette gir en viss naturlig avgrensning av rettsområdet, og læren er henvist til både i litteratur, forarbeider for spesiallovgivningen og i rettspraksis. Men hva som rettslig sett ligger i uttrykket «lare», er ikke klart definert. En ulovfestet lære er et samspill mellom rettspraksis og teori. ${ }^{10}$ Ofte vil teorien systematisere rettspraksis, slik at en rekke enkeltavgjørelser kan tolkes slik at de utgjør en lære. Men fravær av lovregulering gjør at en ulovfestet lære gjerne vil være et fleksibelt verktøy for rettsanvenderen. Fravær av faste vilkår eller tvungne hensyn kan gjøre lærens anvendelsesområde vanskelig å angi presist.

Når jeg har valgt som tittel for avhandlingen «tilbakesøkning ved feilbetaling», er det for å fristille meg fra spørsmålet rundt rekkevidden av condictio indebiti. Det interessante, og det jeg skal undersøke, er hvordan Høyesterett faktisk går frem, ikke hvilke begreper de bruker. Ved å analysere saker hvor Høyesterett har måttet ta stilling til krav om tilbakesøkning på grunn av feilbetaling, kan man finne fellestrekk for når Høyesterett går over til en konkret helhetsvurdering. Dette vil si noe om tilbakesøkningens anvendelsesområde. Deretter kan man undersøke hvilke forhold som spiller inn i helhetsvurderingen. Dette vil si noe om vurderingstemaet for helhetsvurderingen.

Den mest sentrale rettskilden for denne oppgaven blir dermed Høyesteretts praksis, og her har jeg fors $\varnothing \mathrm{kt}$ å innhente all relevant høyesterettspraksis fra de siste 75 år. ${ }^{11}$ Samtidig er formålet

\footnotetext{
${ }^{9}$ Ibid. side 694, jf. side 701.

${ }^{10}$ Se generelt om samspillet mellom teori og rettspraksis, herunder utviklingen av rettslige lærer, hos Eckhoff (2001) side $271 \mathrm{flg}$.

${ }^{11}$ Ved innhentingen av rettspraksis har jeg gjort søk i lovdata på «condictio indebiti», «tilbakesøkning», «tilbakesøking», «tilbakebetaling», «tilbakeføring» og «restitusjon». Fra denne praksisen har jeg sortert vekk
} 
med avhandlingen å rasjonalisere og systematisere rettsstoffet om tilbakesøkning på ulovfestet grunnlag. Noen spørsmål er helt ubesvart i rettspraksis, og andre spørsmål kan man i beste fall bare forsøke å gi svar på ved å trekke slutninger fra hva Høyesterett gjør, uten at man har klare holdepunkter i hva Høyesterett faktisk sier. Dermed blir ikke avhandlingen en rent deskriptiv utlegning av «gjeldende rett»; den vil også ha normative innslag om hvordan man $b \phi r$ gå frem i møte med enkelte uavklarte rettsspørsmål, og hvordan man kan systematisere stoffet.

Som det vil fremgå av avhandlingen, bærer ulovfestet tilbakesøkning mer preg av en rettslig standard enn en rettsregel som setter klare rammer for rettsanvendelsen. ${ }^{12}$ Innenfor de ytterrammer som eventuelt settes av Høyesteretts praksis, må det derfor kunne trekkes inn andre argumentkilder for hvordan rettspraksis bør forstås, og hvordan man bør gå frem ved uavklarte spørsmål. ${ }^{13}$ Når jeg forsøker å finne frem til hvilket argumentasjonsmønster som bør anlegges innenfor rammen av gjeldende rett, vil jeg derfor også se til andre kilder for argumenter for gode løsninger, slik som spesiallovgivning, uttalelser fra sivilombudsmannen, litteratur og utenlandsk rett. Når jeg i oppgaven benytter utenlandsk rett, vil dette være for å hente inspirasjon til systematikk og argumentasjon ved løsning av problemer vi også står overfor i norsk rett. Jeg vil i all hovedsak legge til grunn oppfattelsen av retten i deres nasjonale juridiske litteratur, uten å foreta en selvstendig analyse av utenlandsk rett.

\section{$1.5 \quad$ Fremstilling videre}

Avhandlingen har ni kapitler. I de tre første kapitlene legger jeg grunnlaget for resten av avhandlingen. I kapittel 2 vil jeg kort gjøre rede for hovedtrekkene ved condictio indebiti. Jeg ser først på hvordan læren tradisjonelt har blitt forstått i teorien. Deretter ser jeg kort på hvordan Høyesterett forholder seg til condictio indebiti, og hva som menes å ligge i «læren». I kapittel 3 vil jeg presisere nærmere hva som ligger i «feilbetaling», hvilke tilfeller som undersøkes, hvilke tilfeller det avgrenses mot, og hvor emnet skal plasseres rettslig.

dommer som knytter seg til tilbakesøkning i kontrakt, i skadeserstatning og som følge av brudd på handlingsnormer i spesiallovgivningen. Med hensyn til condictio indebiti har det vært store skifter i rettspraksis, hvor man i eldre praksis både var kritisk til om ulovfestet tilbakesøkning kunne aksepteres i prinsipp, og særlig om det var krav om at betalingen måtte vært gitt under forbehold. I tillegg er vurderingstemaet sterkt skjønnspreget, slik at skiftende verdioppfatninger kan medføre at vurderingene har lite overføringsverdi til i dag. Derfor har jeg avgrenset mot rettspraksis som er eldre enn 75 år, samtidig som at jeg vil benytte enkelte eldre dommer som argumentskilder.

12 Se punkt 2.2.2.

${ }^{13}$ Se generelt om fremgangsmåten ved «rasjonalisering» av rettslige standarder i Knoph (1939) side 29-44. 
I kapittel 4 vil jeg besvare den første problemstillingen, nemlig hvilke grunnvilkår som må vare oppfylt for at Høyesterett skal ta stilling til et krav om tilbakesøkning i feilbetalingstilfellene. I dette kapittelet vil jeg gjøre en analyse av Høyesteretts praksis.

Kapittel 5 og 6 vil besvare den andre problemstillingen, nemlig hvordan Høyesterett konkret argumenterer når de tar stilling til om et tilbakesøkningskrav skal føre frem eller ikke. Her vil jeg analysere saker hvor Høyesterett har tatt stilling til tilbakesøkningskravets materielle side. I kapittel 5 vil jeg undersøke om det finnes enkelte sakstyper hvor Høyesterett ikke finner grunn til å foreta en helhetsvurdering, og om det for disse kan utledes en hovedregel. Deretter vil jeg i kapittel 6 se på hvilke momenter som trekkes inn der det foretas en helhetsvurdering, og undersøke om man kan si noe generelt om slutninger og vekt fra disse momentene. Hensikten her blir å systematisere de momenter som går igjen i praksis, og på denne måten kunne gi klarere veiledning til hvilke argumenter som er relevante ved spørsmål om tilbakesøkningskravet skal føre frem.

I kapittel 7 går jeg videre i undersøkelsen av helhetsvurderingen. Jeg vil her se på hvorvidt andre kilder kan bidra til å klargjøre vurderingstemaet for helhetsvurderingen. Dette kapittelet får dermed et normativt innslag, samtidig som jeg søker å identifisere fremgangsmåter innenfor rammen av og med støtte i gjeldende rett.

I kapittel 8 vil jeg gi en samlet konklusjon for problemstillingene som er reist i avhandlingen. Til sist vil jeg i kapittel 9 komme med noen avsluttende de lege ferenda-betraktninger. 


\section{$2 \quad$ Læren om condictio indebiti i norsk rett}

\subsection{Tradisjonell forståelse av condictio indebiti}

\subsubsection{Innledning}

Læren om condictio indebiti har sitt utgangspunkt i romerretten. Vilkårene for condictio indebiti var her at betaleren måtte være uforpliktet (indebitum solutum), og at det måtte foreligge en unnskyldelig villfarelse hos denne (solutio per errorem). ${ }^{14}$ Dersom vilkårene for condictio indebiti var oppfylt, var hovedregelen etter romersk rett at tilbakeføring av betalingen skulle finne sted. ${ }^{15}$

I Norge og Skandinavia for $\varnothing$ vrig ble det aldri gjennomført en kodifisering av privatretten. Dermed er læren hos oss utviklet i samspill mellom rettspraksis og faglitteraturen. I skandinavisk rett var det i begynnelsen stor skepsis til generelle regler om tilbakeføring som ikke var avtalt mellom partene, herunder condictio indebiti. ${ }^{16}$ Gjennom annen halvdel av 1800-tallet fikk læren derimot fremvekst og ble brukt som grunnlag for tilbakesøkning i praksis. Samtidig gav ikke praksis et entydig bilde av hva som konkret lå i læren. Det som imidlertid har vært klart, er at man ikke har ønsket å oppstille en generell hovedregel om tilbakesøkning, men har måttet foreta en konkret helhetsvurdering. ${ }^{17}$

\subsubsection{Anvendelsesområde}

Hovedlinjene i dagjeldende rett ble trukket opp i Arnholms avhandling fra 1939. ${ }^{18}$ Den senere litteraturen har i stor grad fulgt samme systematikk. Det er enighet i litteraturen om at condictio indebiti kan brukes som navn eller stikkord for et grunnlag man kan bygge krav om tilbakesøkning på. ${ }^{19}$ Hvilke forhold som må foreligge for at grunnlaget kan anvendes, er imidlertid mer uklart. Arnholm bygger på at det måtte foreligge tre «almindelige betingelser» for at læren om condictio indebiti skulle komme til anvendelse. For det første måtte det være foretatt en ytelse, altså betalingshandlingen. For det annet måtte det ikke foreligge noen betalingsplikt. Og for det tredje måtte det foreligge villfarelse hos betaleren. ${ }^{20}$

\footnotetext{
${ }^{14}$ Zimmermann (1990) side 848 flg.

${ }^{15}$ Ibid. side 834 og side 848 flg.

${ }^{16}$ Se særlig Ørsted (1930) side 264 flg. Se generelt om synet på tilbakesøkning i skandinavisk rett hos Arnholm (1939) side $125 \mathrm{flg}$.

${ }^{17}$ Se f.eks. Rt. 1927 s. 237.

${ }^{18}$ Arnholm (1939) side 125 flg.

${ }^{19}$ Se f.eks. Arnholm (1974) side 154 flg., Augdahl (1978) side 394 flg. og Hagstrøm (2011) side 700 flg.

${ }^{20}$ Arnholm (1939) side 173 flg.
} 
Hva gjelder de to første betingelsene, fremstår de som helt nødvendige, og det er her ikke synlig uenighet i litteraturen. Dersom det ikke har skjedd en ytelse, er det heller ikke noe å tilbakebetale. Heller ikke der det forelå betalingsplikt, er det noen grunn til at ytelsen skal kunne kreves tilbake. I disse tilfellene står man jo overfor en ordinær oppfyllelse av en forpliktelse.

Med hensyn til spørsmålet om villfarelse har dette vært mer omstridt. Arnholm fremholdt at vilkåret om villfarelse hos betaleren ikke måtte tolkes for strengt. Hovedhensynet var å avgrense mot de tilfeller hvor betaleren var klar over så vel de faktiske som de rettslige forhold, men valgte å betale til tross for at ingen rettslig plikt forelå. I så fall hadde forpliktelsen fått sitt eget grunnlag, det være seg gave eller lignende. ${ }^{21}$ Bergsåker definerer condictio indebiti som «tilbakebetaling når betaling er skjedd pga. en villfarelse om betalingspliktens eksistens eller omfang», uten å presisere hva som kreves av en eventuell villfarelse. ${ }^{22}$ Samtidig fremgår det av samme bok at heller ikke Bergsåker mener at det er noe ubetinget krav om komplett villfarelse. ${ }^{23}$ Hagstrøm på sin side nevner innledningsvis under kapittelet om condictio indebiti at det er tale om tilfeller hvor det er foretatt en oppfyllelseshandling uten at det forelå forpliktelse «typisk - men ikke bare - fordi vedkommende ikke vet at han er uforpliktet.» ${ }^{24}$ Han viser først til de romerrettslige forutsetninger for condictio indebiti før han konstaterer at «krav etter condictio indebiti kan føre frem selv om betaleren mente ikke å være forpliktet», med henvisning til Rt. 1988 s. $556 .{ }^{25}$ Hva som er avgrensningskriterium for «krav etter condictio indebiti», er imidlertid noe uklart.

\subsubsection{Materielt innhold}

Dersom læren om condictio indebiti kom til anvendelse, mente Arnholm i 1939 at «det i nogen grad [vil] bero på en all round-betraktning av det enkelte tilfelle om tilbakesøkning skal tillates eller ikke.» ${ }^{26}$ Også Krüger og Hagstrøm viser til at læren kan karakteriseres som en rettslig standard, hvor utfallet følger av en helhetsvurdering. ${ }^{27}$ Hagstrøm sammenfatter rettspraksis til at «tilbakes $\emptyset$ kningskrav anerkjennes eller nektes alt ettersom det ene eller det annet resultat under de konkrete omstendigheter finnes å være det mest rettferdige. Og hva som er det mest rettferdige, avgjøres etter en helhetsvurdering.» ${ }^{28}$ Likeledes viser Bergsåker til at

\footnotetext{
${ }^{21}$ Ibid. side 180.

${ }^{22}$ Bergsåker (2015) side 279.

${ }^{23}$ Ibid. side 269.

${ }^{24}$ Hagstrøm (2011) side 700.

${ }^{25}$ Ibid. side 702 .

${ }^{26}$ Arnholm (1939) side 187-188.

${ }^{27}$ Se Krüger (1984) side 312 og Hagstrøm (2011) side 703.

${ }^{28}$ Hagstrøm (2011) side 704.
} 
hvorvidt tilbakesøkning kan kreves eller ikke, «må avgjøres etter en helhetsvurdering ut fra sakens individuelle omstendigheter», med henvisning til Rt. 1985 s. $290{ }^{29}$

Når det gjelder hva som er relevant ved den konkrete helhetsvurderingen, viser Hagstrøm til oppgjørshensyn som taler mot tilbakes $\varnothing \mathrm{kning}$, og korreksjonshensyn som taler for tilbakes $\emptyset \mathrm{k}-$ ning. Oppgjørshensynene vektlegger at man ikke bør rokke ved det som oppfattes som endelig oppgjør, mens korreksjonshensynene går ut på at en betaling som skyldes en feil, bør korrigeres. ${ }^{30}$ Med hensyn til den konkrete vurderingen viser Hagstrøm til en rekke momenter som er tillagt vekt i rettspraksis, men presiserer at «[o]ppregningen på ingen måte er uttømmende. Og ingen av de nevnte momenter er av den art at det fortjener relevans - enn si å tillegges avgjørende betydning - under alle omstendigheter.» ${ }^{31}$ Blant momentene ved vurderingen vises til partenes subjektive forhold, herunder om betaleren har vært i tvil om betalingen, om det er betalt under forbehold eller protest, om mottager har $\varnothing v e t$ betalingspress, partenes profesjonalitet, ytelsens art og hvor mye tid som har forløpt mellom betaling og tilbakebetalingskravet. ${ }^{32}$ Tilsvarende momentlister finner man også hos andre forfattere. ${ }^{33}$

Enkelte typetilfeller blir fremhevet i litteraturen hvor man mener at et forhold må kunne gi et relativt klart svar på om tilbakesøkning skal føre frem eller ei. Således nevner Bergsåker og Augdahl at man ved betaling av foreldet gjeld som hovedregel er avskåret fra å kreve tilbakesøkning. ${ }^{34}$ Et annet typetilfelle som flere mener bør lede til en hovedregel om tilbakebetaling, er tilfellene hvor mottager har vært i ond tro ved mottagelsen av beløpet. ${ }^{35}$ Hagstrøm behandler disse tilfellene for seg selv og mener tilbakes $\emptyset$ kning her kan kreves etter analogi fra avtaleloven $\S 33$, slik at det er unødvendig å gå veien om condictio indebiti. ${ }^{36}$

Utover de momenter fra rettspraksis som trekkes frem, og enkelte typetilfeller hvor man i henhold til rettspraksis kan antyde en presumpsjon for det ene eller annet resultat, gir litteraturen lite veiledning med hensyn til det konkrete vurderingstemaet ved helhetsvurderingen.

\footnotetext{
${ }^{29}$ Bergsåker (2015) side 272.

${ }^{30}$ Hagstrøm (2011) side 705. Se også Bergsåker (2015) side 273 flg.

${ }^{31}$ Hagstrøm (2011) side 705.

32 Ibid. side 705 flg.

${ }^{33}$ Se Bergsåker (2015) side 276 flg. Se også Augdahl (1978) side 401 flg.

${ }^{34}$ Bergsåker (2015) side 274 og Augdahl (1978) side 401.

${ }^{35}$ Bergsåker (2015) side 276 og Krüger (1984) side 310-311.

${ }^{36}$ Hagstrøm (2011) side 700. Se tilsvarende hos Arnholm (1974) side 153.
} 


\section{$2.2 \quad$ Utgangspunkter for gjeldende rett}

\subsubsection{Rettslig grunnlag for forpliktelse}

Condictio indebiti utgjør et selvstendig rettslig grunnlag for en forpliktelse. Med rettslig grunnlag menes her et grunnlag man kan bygge krav på som kan håndheves ved domstolene. At condictio indebiti er et grunnlag, følger klart av Høyesteretts praksis. I flere dommer uttaler Høyesterett eksplisitt at condictio indebiti er «grunnlaget» for tilbakes $\varnothing$ kningskravet. ${ }^{37} \mathrm{I}$ andre dommer omtales condictio indebiti som «hjemmel». ${ }^{38}$

Når man står overfor et grunnlag, må det foreligge noen rettsstiftende fakta som gjør at grunnlaget kan påberopes. Således må den som krever retting på grunnlag av misligholdt kontrakt, først kunne vise at det er inngått en kontrakt, før domstolen kan ta stilling om den er misligholdt. Tilsvarende må den som krever erstatning, kunne vise at det er skjedd en skade, før domstolen kan ta stilling til om det foreligger ansvarsgrunnlag, økonomisk tap og adekvat årsakssammenheng. På samme måte finnes begrensninger på anvendelsesområdet til condictio indebiti. I både Rt. 2004 s. 782 og i Rt. 2003 s. 172 kom Høyesterett til at betingelsene for anvendelse av condictio indebiti ikke forelå, og man kunne dermed ikke gå videre til en konkret helhetsvurdering. ${ }^{39}$

Det som imidlertid er klart i lys av Høyesteretts senere rettspraksis, er at man ikke bygger på et skarpt avgrenset anvendelsesområde, slik at tradisjonelle oppfatninger av betingelser for tilbakesøkning må revideres. Således uttales det i Rt. 2001 s. 1580 at det «ikkje kan byggjast på eit formelt condictio indebitiomgrep.» ${ }^{40}$ Dette er gjentatt i Rt. 2010 s. $816 .{ }^{41}$ I andre saker er det i det hele uklart om Høyesterett mener å bygge på condictio indebiti som grunnlag, direkte eller analogisk, eller om de mener det finnes et ulovfestet grunnlag for tilbakes $\varnothing$ kning som ikke behøver begrunnes i analogi fra condictio indebiti. ${ }^{42}$

\subsubsection{Grunnlagets materielle side}

Dersom man er kommet til at læren om condictio indebiti kommer til anvendelse, følger det av rettspraksis at «[d]et er et grunnleggende trekk i læren om condictio indebiti at hvert tilfelle

\footnotetext{
${ }^{37}$ Se bl.a. Rt. 2013 s. 1665 (premiss 40), Rt. 2010 s. 1500 (premiss 63-64), Rt. 2008 s. 738 (premiss 39), Rt. 2001 s. 1580 (side 1585) og Rt. 1997 s. 1029 (side 1035).

${ }^{38}$ Rt. 2012 s. 1444 (premiss 34).

${ }^{39}$ Se Rt. 2004 s. 782 (premiss 33) og Rt. 2003 s. 172 (premiss 39).

${ }^{40}$ Jf. Rt. 2001 s. 1580 (side 1586), med henvisning til Rt. 1998 s. 989 (side 999).

${ }^{41}$ Rt. 2010 s. 816 (premiss 60).

${ }^{42}$ Rt. 2001 s. 1580 (se særlig nest øverste avsnitt på side 1586).
} 
skal vurderes konkret og under hensyn til rimelighet.» ${ }^{43}$ Dette er forstått slik at det må foretas en «konkret helhetsvurdering». ${ }^{44}$

Når skjønnstemaet for tilbakesøkning angis så vidt som vist ovenfor, er det som tidligere nevnt nærliggende å karakterisere læren som en rettslig standard. Høyesterett omtaler selv vurderingstemaet som «vidt og standardpreget». ${ }^{45}$ Man står ikke overfor en rettsregel, hvor man simpelthen kan vurdere om de enkelte vilkår er oppfylt, for deretter å anvende regelen og komme til et gitt resultat.

\subsubsection{Oppsummering}

Som vist ovenfor, brukes betegnelsen «condictio indebiti» om et rettslig grunnlag for en forpliktelse til å tilbakeføre noe. Men rettspraksis bygger ikke på et klart avgrenset eller formelt begrep. Tvert imot. Det er ikke klart i hvilke tilfeller «læren»kommer til anvendelse. Der grunnlaget kommer til anvendelse, følger det av rettspraksis at det skal foretas en konkret helhetsvurdering. Man har altså ingen uttalt hovedregel, og det at man faller innenfor grunnlaget, gir dermed ikke noe krav i seg selv.

Når man i rettspraksis snakker om «laeren om condictio indebiti» eller «reglene om condictio indebiti», fremstår det først og fremst som at man sikter til den materielle siden av condictio indebiti. ${ }^{46}$ Dette illustreres ved at Høyesterett uttalt ikke bygger på et formelt condictio indebiti-begrep. Høyesterett viser flere ganger at de ikke forholder seg til faste vilkår for «lærens» anvendelse. Den formelle siden kan derfor ikke utgjøre kjernen av condictio indebiti. Derimot benyttes grunnlagets materielle side i flere saker hvor Høyesterett selv uttaler at de muligens er utenfor hva som tradisjonelt er ansett som en condictio indebiti-situasjon. ${ }^{47}$ Dermed er det helhetsvurderingen, en skjønnspreget vurdering med karakter av en rettslig standard, som synes å utgjøre det sentrale i læren om condictio indebiti. Det blir da også helhetsvurderingen som reelt sett utgjør grunnlaget for tilbakesøkning. Når dette grunnlaget kommer til anvendelse, sier imidlertid Høyesterett lite eksplisitt om. På denne bakgrunn fremstår det som at condictio indebiti nettopp er et stikkord for å komme seg til en konkret helhetsvurdering av hvorvidt det er rimelig å la tilbakesøkning føre frem eller ikke.

\footnotetext{
${ }^{43}$ Rt. 1985 s. 290 (side 294).

${ }^{44}$ Se bl.a. Rt. 1998 s. 989 (side 999).

${ }^{45}$ Rt. 2008 s. 738 (premiss 41).

46 Se bl.a. Rt. 2010 s. 816 (premiss 60), Rt. 2008 s. 738 (premiss 41), Rt. 2001 s. 1580 (side 1586), Rt. 1998 s. 989 (side 999), Rt. 1997 s. 1029 (side 1035), Rt. 1995 s. 1641 (side 1651) og Rt. 1985 s. 290 (side 294).

${ }^{47}$ Rt. 2010 s. 816 (avsnitt 60).
} 


\section{$3 \quad$ Presiseringer og rettslig plassering}

\subsection{Innledning}

I kapittel 2 har vi sett at uttrykket condictio indebiti fungerer som et stikkord for et ulovfestet grunnlag for tilbakes $ø$ kning ved feilbetalinger. Hvilke tilfeller som faller innenfor anvendelsesområdet til dette grunnlaget, er likevel uklart. Når Høyesterett uttaler at man ikke kan bygge på et «formelt condictio indebitiomgrep», kan man stille spørsmål ved om condictio indebiti i det hele tatt er et begrep; uttrykket gir i alle fall ingen «klart avgrenset og allmenn-gyldig forestilling ${ }^{48}$ Det man har, er et fremmed ord for en rekke uensartede tilfeller. Derfor vil jeg også fors $ø$ ke å unngå å benytte uttrykket i avhandlingen. Skal det gis en fellesbetegnelse på det rettslige grunnlaget for tilbakes $\varnothing$ kning her, holder jeg meg til «tilbakes $ø$ kning på ulovfestet grunnlag», da dette i det minste sier noe om hva man står overfor, uten å gi unødvendige assosiasjoner til en «lære» med et uavklart innhold.

Når jeg skal gå videre til å analysere Høyesteretts praksis, kan jeg dermed ikke begrense meg til saker hvor det er vist til condictio indebiti. De sakene som skal analyseres, er de sakene som materielt sett gjelder tilbakes $\emptyset$ kning ved feilbetaling. Jeg må derfor definere hva som ligger i uttrykket «feilbetaling» for denne avhandlingen.

\subsection{Uttrykket «feilbetaling»}

Uttrykket «feilbetaling» har ikke hevd i norsk juridisk språkbruk, og finnes ikke igjen i Høyesteretts begrunnelser. ${ }^{49}$ I litteraturen finner vi begrepet «mistaksoppfylling» hos Lilleholt. Han bruker det om tilfeller hvor det er «oppfylt under den mistekne oppfatninga at han oppfyller ei yteplikt overfor mottakaren.» ${ }^{50}$ Uttrykket brukes der som en erstatning for det uklare stikkordet «condictio indebiti».

Også i utenlandsk rett blir uttrykk som kan oversettes til feilbetaling, benyttet. I svensk rett har uttrykket «misstagsbetalning» vunnet hevd både i litteratur og rettspraksis. Uttrykket omfatter «condictio indebiti-situationerna» hvor det er «skett en icke avsedd förmögenhetsförskjutning som saknar rättslig grund.» ${ }^{51}$ Samtidig omfatter «misstaksbetalning» også rene feilskrivninger, slik som var tilfellet i NJA 2011 s. 739. Lindskog definerer «misstagsbetalning» vidt, slik at det kan omfatte både villfarelse om betalingsplikten, og om betalingsmottageren, så vel som at selve betalingen er skjedd ved en feil. Også tilfeller som vi vanligvis ikke tenker på som feil, kan henføres under begrepet «misstagsbetalning», slik som betalinger som

\footnotetext{
${ }^{48}$ Se «begrep» i Bokmålsordboka (1997) side 40.

${ }^{49}$ Men uttrykket er nevnt ved gjengivelsen av partenes anførsler i Rt. 2004 s. 782 (premiss 15).

${ }^{50}$ Lilleholt (2017) side 494.

${ }^{51}$ Jf. NJA 1994 s 177 (på side 183), se tilsvarende formulering i NJA 2011 s. 739 (på side 743).
} 
rettsordenen ikke godtar. ${ }^{52}$ I engelsk rett utgjør «mistaken payment» det mest sentrale rettsstiftende faktum for tilbakes $\varnothing$ kningskrav ved «unjust enrichment». ${ }^{53}$ Utrykket kan oversettes med «mistaksbetaling» eller «feilbetaling». Også i engelsk rett har begrepet kommet til å omfatte mer enn rene villfarelser om betalingsforpliktelsen. ${ }^{54}$

For denne avhandlingen faller derfor valget på «feilbetaling». Uttrykket er like vidt som «mistak», «misstag» og «mistaken», men i bokmålsdrakt. Uttrykket dekker det sentrale rettsstiftende faktum jeg vil unders $\varnothing$ ke: Betalingen skyldes en feil, fordi den ikke korresponderer med en rettslig forpliktelse.

\subsection{Betaling uten rettsgrunn}

Når jeg så har valgt uttrykket feilbetaling, er jeg kommet et stykke videre fra det relativt ubestemte «condictio indebiti». Men fortsatt gjenstår å avklare når betalingen skyldes en feil.

Dersom jeg betaler en gjeld jeg ikke hadde tenkt å betale, kan man i hverdagsspråket si at man står overfor en feilbetaling. Men i rettslig forstand er det ikke dette vi ser etter. På dette punktet kan vi gå tilbake til det tradisjonelle grunnvilkåret for condictio indebiti: Det må være betalt uten at det foreligger en rettslig betalingsforpliktelse.

I svensk rett formuleres dette som et krav om tilbakebetaling fordi betalingen «saknar rättsgrund». ${ }^{55}$ Tilsvarende betegner Birks det sentrale kjennetegnet for alle typer krav basert på «unjust enrichment» at det var en «absence of basis» for berikelsen, altså at det ikke forelå noen grunn for mottagerens berikelse. ${ }^{56}$ Også i fransk rett bygger tilbakesøkning ved «betaling av ikke-skyld» ${ }^{57}$ på at det har skjedd en «overføring uten grunn». ${ }^{58}$

I definisjonen av feilbetaling må derfor tas inn som et grunnvilkår at betalingen er skjedd uten at det forelå rettsgrunn for den. Vi kan tale om betaling uten rettsgrunn. Med dette sikter jeg til at betalingen ikke går til oppfyllelse av en rettslig forpliktelse, og at betalingen heller ikke stifter en ny forpliktelse. Dette grunnvilkåret gjenfinnes i spesiallovgivningen om tilbakes $\varnothing \mathrm{k}$ ning: Folketrygdloven $\S 22-15$ oppstiller som det sentrale vilkår at betaling er foretatt til noen

\footnotetext{
${ }^{52}$ Lindskog (2018) side 818-819.

${ }^{53}$ Burrows (2012) side 64. Se også Birks (2005).

${ }^{54}$ Burrows (2012) side 63 flg.

${ }^{55}$ Lindskog (2018) side 818.

${ }^{56}$ Birks (2005) side $129 \mathrm{flg}$.

${ }^{57}$ Den franske betegnelsen er «paiement de l'indu», se Code civil artikkel 1300, jf. 1302.

${ }^{58}$ Den franske betegnelsen er «versement sans cause», se Bénabent (2017) side 358.
} 
som «ikke hadde krav på den», ${ }^{59}$ etter skattebetalingsloven § 7-3 kan man kreve trekk tilbakebetalt dersom det ikke forelå skatteplikt, ${ }^{60}$ og etter barneloven $\S 80$ kan fostringstilskudd kreves tilbake dersom man blir «friteken for farskapen til barnet». ${ }^{61}$ Alle bestemmelsene illustrerer at det er der hvor grunnlaget for betalingen er bortfalt eller har vist seg ikke å foreligge, at man kan kreve tilbakebetaling. Det viser seg altså at betalingen har vært uten rettsgrunn.

\subsection{Avgrensning mot andre typer betaling uten rettsgrunn}

Ovenfor har jeg vist at en feilbetaling forutsetter at det ikke foreligger rettsgrunn for betalingen. Men alle typer betaling uten rettsgrunn faller ikke innenfor uttrykket «feilbetaling». En feilbetaling er altså alltid en betaling uten rettsgrunn, men en betaling uten rettsgrunn er ikke alltid en feilbetaling.

Når jeg skal undersøke feilbetalinger i denne avhandlingen, må jeg derfor avgrense mot andre typer betaling uten rettsgrunn. I denne kategorien faller uanmodet forretningsførsel, også kalt negotiorum gestio eller tjenester uten oppdrag. For det første står man her ikke overfor en betaling, da rettsinstituttet forutsetter fravær av forpliktelse. For det annet står man ikke overfor en feil, men en frivillig ivaretagelse av andres interesser. ${ }^{62}$

Restitusjonsoppgjør ved hevning faller utenfor, da det her har foreligget en gyldig forpliktelse som senere er hevet. Betalingen var altså ikke uten rettsgrunn da den fant sted. Derimot er restitusjonsoppgjøret ved ugyldige avtaler en type tilbakesøkning av betaling uten rettsgrunn. Her er nettopp poenget at avtalen aldri var bindende for partene. Utgangspunktet her er at partene tilbakefører de ytelsene som var gjort i tillit til at avtalen var gyldig. ${ }^{63}$ Likevel har avtalerettslig ugyldighet tradisjonelt vært behandlet for seg selv, slik at ugyldighetsreglene står på egne ben som grunnlag for tilbakesøkning. ${ }^{64}$ I disse tilfellene er det stort sett tilstrekkelig å konstatere ugyldighet, uten at man har måttet gå veien om condictio indebiti for å gi medhold i tilbakesøkningskrav. ${ }^{65}$ Da disse tilfellene løses på et selvstendig grunnlag, faller de også utenfor fremstillingen i denne avhandlingen.

Noen ganger er ugyldigheten knyttet til at avtalen har et ugyldig innhold. Disse tilfellene skiller seg fra avtaler hvor ugyldigheten knytter seg til en viljesmangel hos en av partene. Et ek-

\footnotetext{
${ }^{59}$ Folketrygdloven $§ 22-15$ første ledd.

${ }^{60}$ Skattebetalingsloven $\S 7-3$ annet ledd bokstav a-c.

${ }^{61}$ Barneloven $\S 80$ første ledd.

${ }^{62}$ Hagstrøm (2011) side 683-684.

${ }^{63}$ Woxholth (2017) side 256-257.

${ }^{64}$ Hagstrøm (2011) side 694.

${ }^{65}$ Woxholth (2017) side 257.
} 
sempel er avtaler som strider mot lov og ærbarhet. ${ }^{66}$ Mens andre typer ugyldighet gjerne vil skyldes at en av partene eller tredjemann har opptrådt på en slik måte at én eller begge av partene må forstå at oppfyllelsen ikke følger av en gyldig rettslig forpliktelse, vil man ved avtaler i strid med lov ofte kunne være i en situasjon hvor man tror at avtalen utgjør en gyldig rettsgrunn for oppfyllelsen. Dermed er denne typen ugyldighet nærmere beslektet med tilfellene av fravær av offentligrettslig hjemmel enn andre tilfeller av avtalerettslig ugyldighet. Også i disse tilfellene vil ugyldigheten bygge på at oppfyllelsen mangler rettsgrunn. Imidlertid vil vurderingstemaet for hvorvidt følgene av ugyldighet i disse tilfellene skal være tilbakesøkning, i stor grad bero på hvorvidt tilbakesøkning har «en gjenopprettende funksjon i forhold til den samfunnsinteresse som er krenket.» ${ }^{67}$ Dermed har de begrenset overføringsverdi for spørsmålet i denne avhandlingen.

Nært beslektet med ugyldighet finner man innkreving av offentlige skatter og avgifter som savner tilstrekkelig hjemmel. Fravær av tilstrekkelig hjemmel innebærer at betalingen er gjort uten rettsgrunn. En stor del rettspraksis om tilbakesøkning på grunnlag av condictio indebiti knytter seg til innbetalinger av skatter og avgifter. Da man i rettspraksis her ikke har bygget på ugyldighet, faller disse sakene innenfor avhandlingens tema.

\subsection{Rettslig plassering av emnet}

Når man spør seg om en feilbetaling kan kreves tilbake, er det spørsmål om å oppstille en rettslig forpliktelse for mottageren. En rettslig forpliktelse må ha et rettslig grunnlag. De to viktigste grunnlag for forpliktelser i norsk privatrett er krav som bygger på kontrakt, og krav som bygger på erstatning for skade. Feilbetalinger tilhører ingen av disse to kategoriene.

I romerretten opererte man med fire kategorier av forpliktelser: kontrakt, delikt, kvasikontrakt og kvasi-delikt. ${ }^{68}$ Condictio indebiti, negotiorum gestio med videre, falt inn i kategorien kvasi-kontrakt. ${ }^{69}$ Uttrykket «kvasi-kontrakt» er kritisert da det ikke har et ensartet innhold og gir antydning på forpliktelser i tilknytning til kontrakt, mens de i realiteten kan oppstå uten at det foreligger noe som helst foregående mellomværende mellom partene. ${ }^{70}$ Likevel er uttrykket videreført i fransk rett, også etter revisjonen av sivillovboken i $2016 .{ }^{71}$ Code civil artikkel 1300 definerer kvasi-kontrakter som «utelukkende frivillige handlinger som medfører en forpliktelse for den som begunstiges uten å ha rett til det, og iblant en forpliktelse overfor

\footnotetext{
${ }^{66}$ Se Norske Lov artikkel 5-1-2.

${ }^{67}$ Hauge (2009) side 470.

${ }^{68}$ Zimmermann (1990) side 14-18.

${ }^{69}$ Ibid. side 15.

${ }^{70}$ Se Birks (2005) side 267-271 og Bénabent (2017) side 345-346.

${ }^{71}$ Code civil artikkel 1300.
} 
andre for den som har handlet». ${ }^{72}$ Etter bestemmelsens annet ledd omfattes uanmodet forretningsførsel (gestion d'affaire), betaling av ikke-skyld (paiement de l'indu) og uberettiget berikelse (enrichissement injustifié). ${ }^{73}$ Det er altså snakk om lovfestede forpliktelser av kontraktslignende art, og ikke av forpliktelser som oppstår i forbindelse med kontraktsforhold. ${ }^{74}$ Den teoretiske begrunnelsen for å ha en lovfestet forpliktelse bygger imidlertid på en tanke om at uberettiget berikelse skal tilbakeføres. ${ }^{75}$

I engelsk rett er som sagt «mistaken payment» et typetilfelle under kategorien «unjust enrichment». Birks argumenterer for at dette er en tredje kategori av forpliktelsesgrunnlag. Det er den uberettigede berikelsen av mottager som gir betaleren et krav om tilbakebetaling, uten at man behøver bygge på hverken kontrakt eller skadeserstatning. ${ }^{76}$ På samme måte viser Burrows til at man i praksis vurderer «unjust enrichment» som en selvstendig kategori adskilt fra kontrakt og skadeserstatning. ${ }^{77}$ At tilbakesøkning av feilbetalinger bygger på en tanke om uberettiget berikelse, ser man også i andre europeiske rettssystemer. ${ }^{78}$

I eldre norsk teori var begrunnelsen for tilbakesøkning gjerne søkt forankret i forutsetningslæren, men en slik begrunnelse forkastes av Arnholm. ${ }^{79}$ Selv bygger Arnholm grunnlaget for tilbakesøkning ved condictio indebiti på at oppfyllelseshandlingen i seg selv blir ugyldig. ${ }^{80}$ Både Augdahl og Hagstrøm synes å plassere tilbakesøkning i en egen kategori av restitusjonsforpliktelser, uten at det er klart hva som er begrunnelsen for slike forpliktelser. ${ }^{81}$ Lilleholt behandler derimot «mistaksoppfylling» sammen med «ugrunna fordel», under kapittelet om andre grunnlag for forpliktelser enn kontrakt. $^{82}$

Motviljen til å begrunne tilbakesøkning av feilbetalinger med henvisninger til «uberettiget berikelse» synes å tegne seg inn i en skandinavisk skepsis mot å bygge på et alminnelig prinsipp om tilbakesøkning av uberettiget berikelse. ${ }^{83}$ I tillegg synes det ikke å være en felles forståelse av hva man legger i «berikelsessynspunkter». Disse viser noen ganger til den opprinnelige berikelsen som grunnlag for kravet, og andre ganger til den bevarte beri-

\footnotetext{
${ }^{72}$ Ibid. første ledd (min oversettelse).

${ }^{73}$ Ibid. annet ledd (min oversettelse).

${ }^{74}$ Bénabent (2017) side 345.

${ }^{75}$ Malaurie (2016) side 607-608.

${ }^{76}$ Birks (2005) side 9.

${ }^{77}$ Burrows (2012) side 27.

${ }^{78}$ Se f.eks. BGB $\S 812$, jf. $§ 814$ og Code des obligations artikkel 63.

${ }^{79}$ Arnholm (1939) side 228 flg.

${ }^{80}$ Ibid. side 234.

${ }^{81}$ Se Augdahl (1978) side 394 flg. og Hagstrøm (2011) side 700 flg.

${ }^{82}$ Lilleholt (2017) kapittel 34.

${ }^{83}$ Vinding Kruse (1950) side 203.
} 
kelsen som begrensning av kravet. ${ }^{84}$ Dermed ble berikelse for Ørsted et argument mot tilbakesøkning som generell regel, da dette ville frarøve mottagere trygghet til å innrette seg på en mottatt betaling. ${ }^{85}$ Ørsted synes altså å sikte til den opprinnelig mottatte berikelsen som grunnlag for tilbakesøkningskravet, uten å operere med en begrensning til bevart berikelse hva gjaldt kravets omfang. Hult derimot synes å se berikelse som en måte å begrense gjenstanden for tilbakesøkningskravet til den berikelsen som fortsatt var i behold hos mottager. Dermed bidrog berikelsessynspunkter for Hult nettopp til at man kunne ha en generell regel om tilbakesøkning, så lenge man gjorde unntak for tilfeller hvor mottager hadde innrettet seg, og hvor man derfor måtte legge til grunn at berikelsen var gått tapt. ${ }^{86}$

For norsk retts vedkommende følger ikke den rettslige plasseringen av tilbakesøkningskrav ved feilbetalinger eksplisitt av Høyesteretts praksis. Det synes likevel klart at den må plasseres i en tredje kategori adskilt fra forpliktelser som springer ut av kontrakt og erstatningsbetingende forhold. At ulovfestet tilbakes $\varnothing$ kning ikke begrunnes i kontrakt, følger forutsetningsvis av Rt. 2010 s. 816, hvor Høyesterett avviser en anførsel basert på «privatrettsleg atterhald [...] om plikt til tilbakebetaling» og heller bygger på ulovfestet tilbakesøkning. ${ }^{87}$ Selv om Høyesterett ikke går «nærare inn på omgrepsspørsmålet, og heller ikkje på om det i denne saka er treffande [...] å rubrisere dette grunnlaget til å gjelde tilbakesøkning på privatrettsleg grunnlag», ${ }^{88}$ viser dommen at ulovfestet tilbakesøkning ikke trenger å bygge på et implisitt løfte om tilbakebetaling ved feilbetaling. At tilbakesøkning er noe annet enn erstatning, følger forutsetningsvis i Rt. 2006 s. 1265 og Rt. 2006 s. $1281 .{ }^{89}$ Dette fremgår for så vidt også ellers av rettspraksis ved ulovfestet tilbakes $\varnothing$ kning ved at man ikke drøfter ansvarsgrunnlag for tilbakebetalingsplikten.

Man står altså overfor et tredje forpliktelsesgrunnlag, som hverken bygger på kontrakt eller erstatning, hvor feilbetaling utgjør et typetilfelle. Hvilke andre krav som faller inn i denne kategorien, og om disse bygger på et felles utgangspunkt, er ikke temaet for denne avhandlingen. ${ }^{90}$ Dermed behøver man heller ikke noe generelt prinsipp om uberettiget berikelse for å forklare tilbakes $\emptyset$ kning av feilbetalinger. ${ }^{91}$ Vi kan simpelthen konstatere at det utgjør et rettslig grunnlag, og at det ikke hører hjemme i kontrakt eller erstatning. Samtidig bør man aner-

\footnotetext{
${ }^{84}$ Denne doble betydningen er påpekt i litteraturen, se Arnholm (1939) side 232 og Lilleholt (2017) side 483484.

${ }^{85}$ Ørsted (1930) side 275-278.

${ }^{86}$ Hult (1947) side 252.

${ }^{87}$ Rt. 2010 s. 816 (premiss 59).

${ }^{88}$ Ibid. (premiss 60).

${ }^{89}$ Se Rt. 2006 s. 1265 (premiss 39-40) og Rt. 2006 s. 1281 (premiss 53).

${ }^{90}$ Om dette, se Birks (2005).

${ }^{91} \mathrm{Om}$ muligheter for å utlede et generelt prinsipp om uberettiget berikelse som grunnlag for krav i norsk rett, se Monsen (2005).
} 
kjenne at tanker om at man ikke uberettiget skal berikes på andres bekostning, er del av det teoretiske fundamentet for denne typen krav. ${ }^{92}$

\subsection{Oppsummering}

Det vi da står igjen med som tema for avhandlingen, er krav om tilbakesøkning som følge av en feilbetaling. For at det skal være en feilbetaling, må det være betalt uten rettsgrunn. Grunnlaget for tilbakesøkningskravet kan ikke være kontrakt eller skadeserstatning. Det er saker i den tredje kategorien forpliktelser som jeg tar for meg. Saker som materielt sett faller innenfor denne definisjonen, vil være gjenstand for analyse, uavhengig av om Høyesterett viser til condictio indebiti eller ei. Hva som utgjør tilstrekkelig rettsgrunn og eventuelt andre grunnvilkår for tilbakesøkning, vil undersøkes i neste kapittel.

\footnotetext{
${ }^{92}$ Eksempler på at tanker om uberettiget berikelse anerkjennes i norsk rett har man i Rt. 2008 s. 738 , Rt. 1934 s. 400 og Rt. 1934 s. 33. Også i Rt. 1998 s. 989 viser Høyesterett til at mottager ville oppnå en tilfeldig gevinst dersom tilbakesøkning ble nektet.
} 


\section{$4 \quad$ Grunnvilkår for tilbakesøkning}

\subsection{Innledning}

I dette kapittelet ser jeg på hvilke grunnvilkår som må være til stede for at tilbakesøkning på ulovfestet grunnlag skal være aktuelt. Jeg går ikke inn i den materielle vurderingen av om et tilbakesøkningskrav skal føre frem, men tar bare for meg de forhold som må foreligge for at Høyesterett i det hele tatt skal gå videre til å foreta en konkret vurdering av om tilbakesøkning bør innrømmes.

I forrige kapittel benyttet jeg kriteriene «betaling» og «fravær av rettsgrunn» for å finne de sakene som materielt sett gjaldt feilbetaling. Når jeg skal undersøke grunnvilkår for ulovfestet tilbakesøkning, er det naturlig å undersøke disse to kriteriene først, altså om og på hvilken måte de kan utgjøre grunnvilkår for tilbakesøkning. Deretter vil jeg undersøke om det fra rettspraksis kan utledes andre inngangskriterier eller begrensninger for tilbakes $\varnothing$ kning.

\subsection{Betaling}

En forutsetning for tilbakesøkning er at noe er ytet. Der ingenting er ytet, kan ingenting søkes tilbake. I alle dommene som er behandlet har det foreligget ytelse. Dette inkluderer alle høyesterettsdommer hvor det er henvist til eller anført condictio indebiti de siste 75 årene, i tillegg til enkelte andre dommer som gjelder feilbetaling. Forutsetningen om at noe allerede er ytet, finner man også igjen i lovregulerte tilbakes $\emptyset$ kningstilfeller. Ser man på lovbestemmelsene om tilbakes $\varnothing \mathrm{kning}$, viser disse at ikke bare tilfeller av betaling av vederlag ved kjøp og salg er omfattet. Tilfellene omfatter utbetalinger fra staten, ${ }^{93}$ pliktige betalinger fra borgere til staten, ${ }^{94}$ pliktige betalinger fra borgere til andre borgere ${ }^{95}$ og feilføringer fra finansinstitusjoner. ${ }^{96}$ Et eksempel som klart faller utenfor hva man tradisjonelt sikter til med betaling, men som like fullt utgjør en formuesoverføring som kan kreves tilbakeført, er tilbakeføring der det er foretatt arveoppgjør etter at noen er erklært død i henhold til lov om forsvunne personar, og vedkommende senere viser seg å være i live. ${ }^{97}$

Grunnvilkåret om ytelse utgjør hovedforskjellen mellom feilbetaling og andre tilfeller som kan falle inn under uberettiget berikelse. Med uberettiget berikelse sikter jeg her til at noen har blitt beriket på andres bekostning, og at denne berikelsen ikke er berettiget som følge av for eksempel gave, handel, risikotagen eller lignende. Berikelsen mangler altså rettsgrunn. Birks argumenterer for at det ikke er noen logisk forskjell mellom feilbetaling og annen type uberettiget berikelse; de bygger begge på at man krever tilbake en berikelse som mottager har

\footnotetext{
${ }^{93}$ Folketrygdloven $\S 22-15$.

${ }^{94}$ Skattebetalingsloven $§ 7-3$.

95 Barneloven $\S 80$.

${ }^{96}$ Finansavtaleloven $\S 31$.

${ }^{97}$ Lov om forsvunne personar kapittel 5, jf. kapittel 3.
} 
oppnådd uten rettsgrunn.$^{98}$ Tilsvarende er tilbakeføring av noe som er prestert uten grunn, Leistungskondiktion, bare en type berikelse i tysk rett. ${ }^{99} \mathrm{I}$ fransk rett er enrichissement injustifié et supplerende grunnlag for å få tilbakeført en uberettiget berikelse oppnådd hos andre, når denne ikke faller inn under reglene om paiement de l'indu. ${ }^{100}$

Der krav om tilbakeføring ved feilbetaling har vært fremmet på ulovfestet grunnlag, har det stort sett ikke vært problemer med betalingsvilkåret. Ikke i noen av sakene har krav blitt avvist fordi man mener at man ikke står overfor en betaling. Alle dommene gjelder pengeytelser. De fleste gjelder krav om tilbakebetaling av innbetalte avgifter eller andre innbetalinger til det offentlige. ${ }^{101}$ Tre dommer gjelder utbetalt forsikring. ${ }^{102}$ I tillegg er det tre dommer om «ordinær» betaling, ${ }^{103}$ og ytterligere tre dommer gjelder innfrielse av lån. ${ }^{104}$ Rettspraksis illustrerer at det sentrale er at det skjer en formuesoverføring fra betaler til mottager.

\subsection{Fravær av foregående forpliktelse}

\subsubsection{Innledning}

Det andre grunnvilkåret for tilbakesøkning er at det ikke må foreligge noen rettsgrunn for overføringen. I alle dommene hvor Høyesterett fant at betalingen savnet rettsgrunn, har de enten gitt medhold i kravet om tilbakebetaling, eller de har foretatt en konkret vurdering av hvorvidt betaling skal føre frem eller ei.

Rettsgrunn kan ta form av foregående forpliktelse, eller det kan være at betalingen utgjør en rettslig bindende disposisjon i seg selv. At fravær av rettsgrunn er et grunnvilkår, finner man igjen både i svensk, fransk og engelsk rett. Lindskog angir forutsetningene for ulovfestet tilbakesøkning som at «(i) ingen rättsgrund för betalningen fanns (ögonblicket) innan betalningen och (ii) at betaleren inte genom betalningen kan anses ha skapat någon rättsgrund». ${ }^{105} \mathrm{Ne}-$ denfor skal vi først se på tilfellene som Lindskog beskriver i bokstav (i). I punkt 4.4 ser vi deretter på de tilfellene hvor betalingen kan utgjøre en selvstendig rettsgrunn.

\footnotetext{
${ }^{98}$ Birks (2005), se særlig side 5-9.

99 Se «Ungerechtfertigte Bereicherung» i BGB, jf. § 812. Første ledd, første punktum omhandler både «Leistungskondiktionen» (første alternativ) og «Nichtleistungskondiktionen» (annet alternativ).

${ }^{100}$ Code civil artikkel 1303.

101 Se Rt. 2012 s. 722 , Rt. 2010 s. 816, Rt. 2008 s. 1510, Rt. 2008 s. 738, Rt. 2003 s. 172, Rt. 1997 s. 1210 , Rt. 1976 s. 579 , Rt. 1959 s. 1129 og Rt. 1953 s. 1460.

102 Se Rt. 1997 s. 1029 , Rt. 1995 s. 1641 og Rt. 1985 s. 290.

${ }^{103}$ Se HR-2016-2491-A, Rt. 2001 s. 1580 og Rt. 1979 s. 69.

${ }^{104}$ Se Rt. 2004 s. 782 , Rt. 1998 s. 989 og Rt. 1988 s. 556.

${ }^{105}$ Lindskog (2018) side 820.
} 
Det er en forutsetning for krav om tilbakesøkning av en feilbetaling at det ikke foreligger foregående rettslig forpliktelse, altså en forpliktelse som kan kreves håndhevet ved domstolene. Dersom tilstrekkelig forpliktelse foreligger, står man ikke overfor en feilbetaling etter den definisjonen jeg har gjort i punkt 3.2 og 3.3. En eventuell tilbakes $\varnothing$ kningsplikt må da begrunnes i kontraktsbrudd eller erstatning. Eksempler på at Høyesterett drøfter spørsmålet om det foreligger en betalingsforpliktelse, og avviser tilbakesøkningskravet på det grunnlag at forpliktelse forelå, finner man blant annet i Rt. 2003 s. 172 og Rt. 1976 s. 579. Førstnevnte sak gjaldt spørsmål om tilstrekkelig hjemmel for vann- og avløpsgebyr, mens sistnevnte gjaldt hjemmel for innkreving av bompenger. I begge tilfeller fant Høyesterett at tilstrekkelig hjemmel forelå, slik at det ikke var tale om fravær av forpliktelse. Dermed var det ikke aktuelt å gå over til en helhetsvurdering av hvorvidt tilbakesøkning var rimelig.

Når jeg undersøker hvordan Høyesterett går frem for å vurdere spørsmålet om foregående forpliktelse foreligger, vil jeg analysere hver for seg situasjoner hvor det hverken foreligger forpliktelse for betaleren eller krav fra mottageren (komplett fravær av rettsgrunn), og situasjoner hvor kun én av partene har en forpliktelse eller et krav, slik at man enten har feil mottager eller feil betaler. I tillegg unders $\varnothing$ ker jeg for seg selv tilfellene hvor det foreligger korresponderende forpliktelser og krav, men hvor forpliktelsen ikke dekker den betalingen som er gitt.

Den systematikken jeg har valgt, tar utgangspunkt i inndelingen i fransk rett. Her skiller man mellom situasjoner hvor det ikke foreligger noen forpliktelse eller krav overhodet, indu objectif (objektiv ikke-skyld), og situasjoner hvor det enten er betalt til feil mottager eller av feil betaler, indu subjectif (subjektiv ikke-skyld). Avhengig av hvilken av de nevnte situasjonene man står ovenfor, har det i fransk praksis, og senere i lovgivningen, blitt oppstilt ulike vilkår og unntak for når tilbakebetaling skal skje. ${ }^{106}$ Den systematiske inndelingen gir således retningslinjer for den materielle vurderingen. I tillegg til de tre kategoriene det opereres med i fransk rett, har jeg som nevnt benyttet en fjerde kategori for situasjoner hvor det ikke foreligger rettsgrunn for betalingen, men hvor det foreligger en avtale eller annet mellomværende mellom partene som kan forklare hvorfor mottageren trodde han hadde krav på betalingen. ${ }^{107}$

\footnotetext{
${ }^{106}$ Se Bénabent (2017) side 358 flg.

${ }^{107}$ Disse tilfellene faller i fransk rett inn under kategorien indu objectif. Da man i disse tilfellene lettere kan se betalingen som en selvstendig disposisjon, finner jeg det likevel nyttig å behandle dem for seg selv. Mer om dette i punkt 4.3.5.
} 


\subsubsection{Komplett fravær av rettsgrunn}

\subsubsection{Fravær av offentligrettslig hjemmel}

Jeg ser først på dommer hvor det hverken har foreligget en betalingsforpliktelse på betalerens hånd, eller et krav på mottagerens hånd. Det er altså komplett fravær av rettsgrunn. Disse sakene utgjør flertallet av sakene om tilbakesøkning.

De fleste sakene hvor det overhodet ikke foreligger rettsgrunn for hverken betaleren eller mottageren, er der det offentlige uriktig har innkrevet avgifter. I de sakene hvor man kom til at hjemmel faktisk ikke forelå, har Høyesterett enten konstatert tilbakesøkning direkte eller gått videre til en konkret vurdering. ${ }^{108}$ I to av sakene kom man til at hjemmelen var tilstrekkelig, slik at rettsgrunn forelå. ${ }^{109}$ Dermed gikk man ikke over til en konkret vurdering, da betalingen uansett gikk til oppfyllelse av en gyldig forpliktelse. Fra ovennevnte kan man se at fravær av hjemmel for innkreving, medfører at betalingen savner rettsgrunn.

\subsubsection{Betalinger som følge av utnyttelse og svik}

Der noen har betalt utfra en feilaktig pliktforestilling som følge av mottagers utnyttelse eller svik, har det vært lagt til grunn at man kan bygge krav om tilbakesøkning på analogi fra avtalelovens $\S \S 30$ og 33. ${ }^{110}$ Dette synspunktet ble bekreftet i HR-2016-2491-A. Saken gjaldt krav om tilbakebetaling av betalinger gjort av prostituerte til sine halliker. Høyesterett konstaterte at det var snakk om «tilbakeføring av verdier som mottakeren ikke var berettiget til.» ${ }^{111}$ Kravet ble bygget på «ulovfestede obligasjonsrettslige prinsipper om restitusjon av ytelser som er gitt uten å være forplikte til det», ${ }^{112}$ og til støtte for et krav om tilbakes $\varnothing$ kning viste Høyesterett til avtalelovens $\S \S 30,31$ og 33, og læren om condictio indebiti. Grunnen til at Høyesterett her måtte gå veien om feilbetaling, og ikke fant å kunne anvende avtaleloven direkte, var at de ikke fant det naturlig å anse betalingene for en viljeserklæring. Med andre ord anså de ikke betalingen som en selvstendig rettslig disposisjon, se punkt 4.4.3.2. Da Høyesterett kom til at det hverken forelå foregående forpliktelse eller at betalingen utgjorde en selvstendig rettslig disposisjon, stod man overfor en betaling uten rettsgrunn.

\subsubsection{Forsikringssakene}

Flere av sakene om tilbakesøkning har angått krav fra forsikringsselskap om tilbakebetaling, hvor det etter utbetaling av forsikringspengene viser seg at vilkårene for forsikringsutbetaling

\footnotetext{
${ }^{108}$ Rt. 2012 s. 1444 , Rt. 2008 s. 1510 , Rt. 2008 s. 738, Rt. 1997 s. 1210 , Rt. 1959 s. 1129 og Rt. 1953 s. 1460.

${ }^{109}$ Rt. 2003 s. 172 , Rt. 1976 s. 579.

${ }^{110}$ Hagstrøm (2011) side 700.

${ }^{111}$ HR-2016-2491-A (premiss 80).

112 Ibid.
} 
ikke var oppfylt, på grunn av svik fra sikrede. Der det er utbetalt til forsikrede, og det senere viser seg at plikten til å utbetale forsikring var bortfalt grunnet forsikredes forhold, er det klart at utbetalingen savnet rettsgrunn. Dersom utbetalingen er fremkalt ved sikredes svik, kan man bygge kravet på erstatning og behøver ikke å gå veien om ulovfestet tilbakesøkning. De saker som har gått for Høyesterett, gjelder imidlertid tilfeller hvor mottager av forsikringssummen er en medforsikret panthaver, mens det er sikrede selv som har handlet slik at retten til forsikring var bortfalt.

Der medforsikredes krav er selvstendig, jf. forsikringsavtaleloven $\S 7-3$, har medforsikrede krav på utbetaling selv om hovedsikrede selv ikke skulle ha noe krav grunnet hovedsikredes forhold. For enkelte forsikringer, herunder sjøforsikring, er medforsikringen vanligvis uselvstendig, hvilket innebærer at medsikrede kan identifiseres med hovedsikrede, se Norsk Sjøforsikringsplan $\S \S 7-1,8-1$, jf. $\S 3-36-3-38 .{ }^{113}$ De saker om tilbakebetaling som har gått for Høyesterett, gjelder da også panthavere i skip. Både i Rt. 1995 s. 1641 og Rt. 1985 s. 290 var skipene senket forsettlig av eieren. Eieren, hovedsikrede, hadde derfor intet krav. Da medforsikringen var uselvstendig, var også panthavernes krav bortfalt. Resultatet ble derfor at det ikke hadde foreligget noen forpliktelse for forsikringsselskapene til å yte hverken ovenfor hovedsikrede eller overfor medforsikrede. Med hensyn til forsikringskravet stod man altså overfor en situasjon med komplett fravær av rettsgrunn.

\subsubsection{Feil mottager}

Der man betaler til feil kreditor, foreligger fravær av rettsgrunn for betalingen. Betaler har en forpliktelse, men oppfyller til noen som ikke har et krav. Et typisk tilfelle vil være at man taster feil kontonummer, altså en ren feilføring. Man kan også tenke seg at man faktisk tror at en annen person enn kreditor er kreditor for kravet.

Det er ingen privatrettslig høyesterettspraksis på de rene feilføringstilfellene, altså hvor man ved en tastefeil har overført beløp til feil person. Derimot finnes enkelte straffesaker som gjelder uberettigede mottagers bruk av mottatte midler. I Rt. 2008 s. 1582 kom Høyesterett til at et par som hadde forbrukt penger som feilaktig hadde blitt overført til deres konto, «vitende om feilen», kunne dømmes til underslag, jf. straffeloven (1902) § 255. I en lignende sak inntatt i Rt. 2003 s. 1243 kom også Høyesteretts flertall til at forholdet falt inn under bestemmelsen om underslag. Den forståelsen som ble lagt til grunn i Høyesterett i disse to sakene, er senere bekreftet i den nye straffeloven (2005) § 324 som nå eksplisitt never «pengefordring» på linje med «løsøregjenstand». Av lovens forarbeider fremgår at det var lovgivers hensikt å ramme de tilfellene hvor noen hadde rådd over midler som feilaktig var overført til deres kon-

${ }^{113}$ Se også Falkanger (2016) side 543 og 536. 
to. ${ }^{114}$ Hva gjelder grunnvilkåret om fravær av rettsgrunn, følger det av denne strafferettspraksisen at man har ansett mottager som fullstendig uberettiget til midlene. Vi kan derfor slutte at overføringen savnet rettsgrunn.

Både lovens og Høyesteretts argumentasjon i disse sakene er strafferettslig, og kontopengene behandles som ting, hvis eiendomsrett ikke i det hele tatt er blitt overført ved feilbetalingen. Krav bygget på condictio indebiti er typisk behandlet som obligatoriske krav og ikke tinglige krav. Da man ikke opererer med et skarpt skille mellom de to i norsk rett, kan likevel ikke dette skillet rokke ved at strafferettsdommene gir gode argumenter for at feilføringstilfellene også må kunne behandles som tilbakesøkningskrav i privatretten. Dette er den løsning som loven gir anvisning på i finansavtaleloven. ${ }^{115}$ Selv om enkelte av bestemmelsene er utpreget positivrettslige, gir henvisningen i finansavtaleloven $\S 31$ fjerde ledd til «alminnelige regler» uttrykk for en forutsetning om at samme tilbakesøkningsadgang må gjelde utenfor lovens virkeområde. Også i svensk rett behandles feilføringstilfellene under reglene om «misstagsbetalning». ${ }^{116}$

Et litt annet tilfelle enn de rene feilføringstilfellene som er omtalt ovenfor, har man der Peder Ås tror han skylder penger til Marte Kirkerud, men i virkeligheten skylder pengene til Lars Holm. I motsetning til den rene faktiske feilen som var tilfellet ovenfor, står vi her overfor noe som ligner mer på et villfarelsestilfelle. Problemstillingen er ikke helt upraktisk; man kan for eksempel tenke seg at man skal gjøre opp etter et spleiselag, og overfører til feil person. Imidlertid har man ikke eksempler på at denne typen tvister har kommet opp i praksis. Skulle det komme opp, bør man like fullt også her kunne konkludere med at betalingen fra Ås til Kirkerud savnet rettsgrunn, slik at det er adgang til tilbakesøkning.

\subsubsection{Feil betaler}

En rekke av tilbakesøkningssakene som har vært oppe for Høyesterett, har angått tilfeller hvor det foreligger et krav, men den som har betalt, ikke er rette debitor. Man står altså overfor tilfeller av innfrielse av andres gjeld.

Den nyeste høyesterettsdommen om innfrielse av andres gjeld er Rt. 2004 s. 782. Saken gjaldt tilbakesøkningskrav fremmet overfor en bank av privatperson (A). A hadde innfridd sin tidligere samboer Bs utleggsgjeld til banken i deres tidligere felles eiendom, i forbindelse med salg av eiendommen. I dommen kom Høyesterett til at det overhodet ikke kunne være aktuelt med tilbakesøkning. Dommen gir etter mitt syn uttrykk for at Høyesterett fant at selv om beta-

\footnotetext{
${ }^{114}$ Ot.prp. nr. 22 (2008-2009) punkt 8.4.2.

115 Finansavtaleloven $\S 31$.

116 NJA 2011 s. 739 (domskälen avsnitt 8).
} 
lingen savnet forutgående forpliktelse, var den ikke uten rettsgrunn, fordi betalingen utgjorde en selvstendig rettslig disposisjon. Dommen blir derfor omtalt nedenfor under punkt 4.4.

En svært spesiell variant av betaling av andres gjeld har man i Rt. 2001 s. 1580. Saken gjaldt krav om tilbakesøkning av midler som var overført fra et borettslag til et byggefirma. Saken er spesiell i den forstand at det ikke var noe mellomværende mellom borettslaget og byggefirmaet. «Feilbetalingen» var en følge av at borettslagets forretningsfører, som også var regnskapsfører i byggefirmaet, hadde overført penger fra borettslaget til byggefirmaet for å dekke sin egen gjeld. For å få det til å fremstå som at det var ham som var betaler, hadde han forfalsket betalingsmeldingen. Flertallet i dommen la avgjørende vekt på at pengene ikke hadde gått via forretningsførerens konto, og at man derfor ikke stod overfor en tredjemannskonflikt. Dermed ble borettslaget selv ansett som betaler, til tross for at borettslaget hverken hadde disponert faktisk eller rettslig ved overføringen. Med den forståelsen av saksforholdet som Høyesterett her la til grunn, stod man overfor en betaling uten rettsgrunn: Borettslaget hadde ingen betalingsforpliktelse overfor byggefirmaet, men hadde betalt forretningsførerens gjeld.

Dommen er kritisert i litteraturen. ${ }^{117}$ I en artikkel i Jussens Venner kritiserer Tørum anvendelsen av condictio indebiti i et tilfelle som dette, ${ }^{118}$ og gir i likhet med Lilleholt støtte til mindretallets votum som anser konflikten som en hjemmelsmannskonflikt. Jeg leser kritikken som rettet mot flertallets vurdering av hvem som var betaler. Denne kritikken er jeg enig i. Som flertallet selv er inne på, ville spørsmålet blitt en tredjemannskonflikt dersom pengene hadde gått via forretningsføreren. Hadde det vært snakk om kontanter, hadde disse som en nødvendighet gått via forretningsførerens besittelse på vei til entreprenørfirmaet. Å oppstille et skille mellom kontopenger og kontanter blir her kunstig. Når flertallet kommer til at borettslaget, til tross for at det overhodet ikke hadde disponert, var betaler, medfører dette at Høyesterett kunne anvende reglene om condictio indebiti i stedet for reglene om godtroerverv. Konsekvensen av dette er at man utvider anvendelsesområdet for en lære hvor Høyesterett har et nærmest ubegrenset skjønn, fremfor å henføre saken under godtroerverv, hvor man har et betydelig mer avklart vurderingstema.

Dissenterende dommer Oftedal Borch kom i motsetning til flertallet til at borettslagets krav måtte ses som et spørsmål om godtroerverv. Mindretallet la til grunn at den teknikalitet at pengene ikke hadde gått via forretningsførerens konto, ikke kunne avskjære at regler for tredjemannskonflikter kom til anvendelse, da realiteten i saksforholdet var det samme. Samtidig kom også mindretallet til at regnskapsførerens handlinger, som ansatt i byggefirmaet, var til hinder for godtroerverv for firmaet. Med den vurdering av faktum som mindretallet gjorde, var betalingen skjedd fra forretningsføreren til byggefirmaet. For denne betalingen forelå en foregående rettslig forpliktelse, og betalingen kunne dermed ikke kreves tilbake på grunnlag av condictio indebiti. Dermed måtte man bygge på reglene for tredjemannskonflikter.

En annen dom om innfrielse av annens gjeld er inntatt i Rt. 1998 s. 989. Saken gjaldt tvist mellom en bank og en av bankens kunders långivere. Bankkunden, rederiet Fearnley \& Eger, hadde tatt opp et såkalt sertifikatlån, det vil si at de hadde tatt opp lån mot utstedelse av gjeldsbrev (sertifikat) til utlånerne (sertifikathaverne). For å tilrettelegge for lånet hadde

\footnotetext{
${ }^{117}$ Se bl. a. Lilleholt (2018) side 262, med videre henvisning til Lilleholt (2003).

118 Tørum (2002) side 334.
} 
Fearnley \& Eger anvendt et meglerfirma, kalt SCM. Meglerfirmaet opptrådte også som tillitsmann for sertifikathaverne. Banken hadde ovenfor SCM påtatt seg et enkeltstående oppdrag, som gikk ut på en betinget forpliktelse til å innfri lånene ved forfall, mot inndekning fra Fearnley \& Eger. Da forfallsdagen kom, innfridde banken sertifikatene, slik at sertifikathaverne fikk sine penger tilbake. Det viste seg imidlertid at inndekning fra kunden ikke ville komme, slik at banken omgjorde betalingen samme dag. Etter protester fra sertifikathaverne utbetalte banken pengene på nytt tre dager senere, men denne gang med forbehold om tilbakesøkning. Bankens kunde gikk senere konkurs, og banken rettet da krav om tilbakebetaling mot sertifikathaverne. Sertifikathaverne hadde altså fått innfridd et gyldig krav, men banken var ikke selv rette debitor for kravet. For Høyesterett var det både spørsmål om banken hadde blitt forpliktet ved den opprinnelige betalingen, og hvis ikke, om tilbakebetalingskravet likevel måtte anses tapt etter en helhetsvurdering. Høyesterett kom i saken til at banken var uforpliktet, og betalingen ble heller ikke ansett for å utgjøre en selvstendig rettslig disposisjon. Dermed var adgangen til å kreve tilbakesøkning i behold. Hvorfor man i denne dommen ikke stod ovenfor en selvstendig rettslig disposisjon, mens man gjorde det i Rt. 2004 s. 782, vil bli forklart under punkt 4.4 .

Også i Rt. 1997 s. 1029 var det spørsmål om tilbakebetaling ved innfrielse av andres gjeld. Saken gjaldt krav om tilbakebetaling av utbetalt forsikringsbeløp. Et rederi hadde fătt utbetalt et forsikringsbeløp fra rederiets daværende forsikringsselskap, Kystskipassuransen, for skader oppdaget i 1992. Det viste seg i ettertid at de oppdagede skadene hadde påbegynt allerede i 1987, da skipet var forsikret av et annet selskap, Uni Storebrand. Dermed hadde det ikke foreligget betalingsplikt for Kystskipassuransen. Selv om kravet ikke førte frem etter en konkret vurdering, var det her klart at grunnvilkåret om fravær av rettsgrunn var oppfylt: Kystskipassuransen hadde betalt et gyldig krav, men de var ikke selv rette debitor for kravet.

Den siste saken, Rt. 1979 s, 69, gjaldt tvist i forbindelse med lånefinansiert kjøp av kjøleutstyr. Kjøper hadde kjøpt utstyret fra selger, men det var avtalt at utstyret skulle faktureres til långiveren, Kjøpmannskreditt, som deretter skulle viderefakturere til kjøper. Tvisten gjaldt selgers provisjon til Kjøpmannskreditt, som var blitt belastet kjøper. Dette fremgikk ikke av avtalen. Derimot hadde denne praksisen utviklet seg over tid mellom Kjøpmannskreditt og en rekke leverandører til næringsvirksomhet, herunder selger, som stod på Kjøpmannskreditts liste. Kjøper rettet krav om tilbakeføring av provisjonen mot både selger og Kjøpmannskreditt. Det første spørsmålet var hvorvidt kjøpsavtalen innebar en forpliktelse for kjøper til å betale Kjøpmannskreditts provisjon. Etter å ha tolket avtalen, kom Høyesterett til at en slik plikt ikke forelå. Dermed var betalingen gjort uten rettsgrunn for kjøpers vedkommende, siden selger, og ikke kjøper, var rette debitor for kravet. 


\subsubsection{Utilstrekkelig rettsgrunn}

\subsubsection{Om utilstrekkelig rettsgrunn}

I dette avsnittet ser jeg på tilfeller hvor det har foreligget gjensidig krav og forpliktelse, men hvor kravet ikke fullt ut dekker oppfyllelsen. Dette vil typisk være tilfeller hvor det er betalt for mye, eller hvor det er betalt til feil tid. Her kan man rent formelt si at man for den delen av det betalte som ikke er dekket av kravet, står overfor komplett fravær av rettsgrunn. ${ }^{119}$ På den andre siden er hensikten bak den inndelingen som er gjort overfor, å skille mellom de tilfeller hvor mottageren har hatt en i utgangspunktet berettiget forventning om å motta oppfyllelsen, og de tilfeller hvor han ikke har hatt en slik forventning. Når det allerede foreligger et avtaleforhold mellom partene, vil en eventuell feilbetaling lettere kunne anses som en ettergivelse av et krav basert på den ene avtalepartens avtaleforståelse. Derfor behandler jeg tilfellene for seg selv.

\subsubsection{For høyt beløp}

I noen saker er det klart at det foreligger gjensidige forpliktelser og krav, men det kan være at det er ytet mer enn man var forpliktet til. I disse tilfeller savner betalingen rettsgrunn for det overskytende. Et eksempel på at det for mye betalte kan kreves tilbake, har man i Rt. $2010 \mathrm{~s}$. 816. Saken gjaldt krav fra kraftselskap om tilbakebetaling av for mye betalt konsesjonsavgift, samt etterbetaling av for store mengder levert konsesjonskraft, fra kundekommuner. Hva gjaldt tilbakesøkningskravet, var det på det rene at man ikke stod overfor en tradisjonell villfarelsessituasjon. Det sentrale forhold for at Høyesterett kunne gå over til en konkret rimelighetsvurdering, var at det var tale om «avgift motteke med urette». ${ }^{120}$ For det overskytende hadde mottager altså ikke krav på betalingen.

Rt. 1953 s. 1460 gjaldt en kommunes krav om tilbakebetaling fra Arbeidsløshetsfondet. I saken hadde man ved en feil krevet premieinnbetaling fra kommunen i egenskap av arbeidsgiver. For en gruppe av arbeiderne hadde det ikke foreligget premiebetalingsplikt, og de premier som var betalt for denne gruppen, kunne kommunen kreve tilbakebetaling for. For denne delen av premieinnbetalingen forelå det med andre ord ikke rettsgrunn. For de $\varnothing v$ rige arbeiderne hadde man korrekt ilagt kommunen premiebetalingsplikt.

\subsubsection{Førtidig betaling}

Rt. 1988 s. 556 gjaldt krav fra en bank om tilbakebetaling fra en obligasjonshaver, Aktuell AS, i et boligprosjekt. Aktuell hadde en pantobligasjon i prosjektet på 800.000 kroner, erver-

\footnotetext{
${ }^{119}$ I fransk rett blir tilfellene ansett som indu objectif, jf. Code civil artikkel 1302, se Bénabent (2017) side 359361 .

${ }^{120}$ Rt. 2010 s. 816 (premiss 61).
} 
vet som sikkerhet ved overdragelsen av byggegrunnen fra Aktuell til eiendomsselskapet. Ved avtale mellom banken, eiendomsselskapet og Aktuell hadde Aktuell påtatt seg å vike prioritet for sin pantobligasjon til fordel for byggelånsobligasjonen på 6.500.000 kroner. Da de første seksjonene i prosjektet var klare for salg i juni 1981, kontaktet banken eiendomsselskapet og bad om fullmakt til å frafalle pantet i eiendommene også for pantet på 800.000 kroner, etter hvert som seksjonene ble solgt, slik at disse kunne selges ubeheftet. Aktuell krevde imidlertid at det ble stillet garanti for innfrielse av obligasjonen, hvilket banken ikke kunne akseptere. På denne bakgrunn så banken ingen annen løsning enn å løse inn obligasjonen for å få solgt seksjonene.

Høyesterett oppstilte som det sentrale spørsmålet i tvisten hvorvidt Aktuell hadde handlet i strid med bestemmelsene om dekningsrekkefølgen, slik disse fulgte av partenes avtale. Нøyesterett tiltrer byrettens vurdering om at Aktuell hadde handlet i strid med avtalen, da det av denne fulgte at Aktuell ikke hadde krav på innfrielse av sin obligasjon før oppgjøret med entreprenøren og byggelånsbanken var dekket.

Med hensyn til foregående forpliktelse er poenget at det på tidspunktet betalingen ble gjort, ikke forelå noen forpliktelse til å betale ennå. Kravet var betalingsmodent, men forfallstiden var ennå ikke inntrådt. Sett fra en slik synsvinkel, åpner dommen døren for at man ved førtidig betaling av gjeld kan ha krav på tilbakebetaling. Et slikt resonnement har vært forfektet i norsk litteratur. ${ }^{121}$ Dommens resultat støtter den tilnærming som er gjort i litteraturen til spørsmålet, hvor man anser tilfellet for en betaling uten rettsgrunn, slik at spørsmålet om tilbakesøkning skal føre frem eller ikke, tas under helhetsvurderingen. Samtidig er ikke dommens begrunnelse knyttet til prinsipielle betraktninger rundt førtidig innfrielse, men til Aktuells kontraktsbrudd. Uten dette elementet av forsettlig kontaktstridig adferd vil nok betaler ha store utfordringer med å kreve tilbakesøkning av førtidig betaling, selv om man prinsipielt skulle tillate det. Dette skyldes at man lett vil kunne anse betalingen som en selvstendig rettslig disposisjon i form av ettergivelse eller lignende. ${ }^{122} \mathrm{I}$ så fall får det liten betydning at det ikke forelå foregående forpliktelse, da betalingen i seg selv innebærer en rettsgrunn. Ut fra dommens begrunnelse er det ikke helt klart om man la til grunn at betalingen utgjorde en selvstendig rettslig disposisjon, som i så fall var ugyldig, eller om man mente at man hverken stod overfor foregående eller etterfølgende rettsgrunn. Den delen av dommen er kommentert nedenfor under punkt 4.4 .

\footnotetext{
${ }^{121}$ Se Arnholm (1939) side 179 og Bergsåker (2015) side 275 (i petit).

${ }^{122}$ Et slikt syn om at førtidig innfrielse av gjeld innebærer en bindende disposisjon, er lagt til grunn i fransk rett, jf. Code civil artikkel 1305-2.
} 


\subsubsection{Betaling av foreldet gjeld}

Det har i teorien vært antatt at den som betaler foreldet gjeld, ikke kan kreve tilbakes $\varnothing \mathrm{k}$ ning. ${ }^{123}$ Arnholm går så langt at han skriver at det er «almindelig samstemmighet om at tilbakesøkning er utelukket for deres [foreldede kravs] vedkommende». ${ }^{124}$ Dette begrunnet han i hensynene bak foreldelsesreglene, og at ingen skade skjer ved at foreldet gjeld betales. ${ }^{125} \mathrm{I}$ kontinentaleuropeiske kodifikasjoner er foreldelse gjerne eksplisitt unntatt reglene om tilbakesøkning, gjerne med henvisning til den romerrettslige læren om obligatio naturalis. ${ }^{126}$

I romerretten viste obligatio naturalis til «forpliktelser» som man ikke kunne kreve rettslig håndhevelse av. Disse omfattet blant annet avtaler inngått med slaver, kvinner og barn. Selv om man ikke kunne kreve rettslig håndhevelse av et krav bygget på obligatio naturalis, hadde de en rettslig betydning i den forstand at innfrielsen av en obligatio naturalis ikke kunne kreves tilbakebetalt etter condictio indebiti. ${ }^{127}$

Etter Rt. 2012 s. 722 kan man ikke uten videre anse tilbakesøkning utelukket ved betaling av foreldet gjeld. I saken betalte et gjenvinningsselskap avgift etter etterberegning. Deler av beløpet viste seg imidlertid å være foreldet, og selskapet krevde pengene tilbake. Høyesterett viste først til at det «alminnelig [er] antatt i juridisk teori at betaling av foreldet gjeld som utgangspunkt avskjærer krav om tilbakebetaling.» ${ }^{128}$ Høyesterett gikk ikke inn på hvorvidt dette utgangspunktet $\mathrm{i}$ alminnelighet stod seg, men viste til at betalingen her var gjort under protest. Da Høyesterett fant at protesten utgjorde et tilstrekkelig klart forbehold om også å kunne påberope foreldelse som betalingsinnsigelse, kunne det faktum at deler av gjelden var foreldet, ikke medføre bortfall av tilbakesøkningskrav.

Dommen tar ikke avstand fra det som tidligere er tenkt om tilbakes $\emptyset$ kningsadgangen ved foreldet gjeld. Den er konkret begrunnet i protesten og kan ikke leses uten at man tar høyde for den konkrete situasjonen. Det dommen gir uttrykk for, er at man kan ta forbehold om tilbakesøkning ved betaling av gjeld man mener er foreldet. Der forbehold ikke er tatt, gir dommen ingen holdepunkter for at Høyesterett ikke vil opprettholde det tradisjonelle utgangspunktet om at tilbakesøkning er avskåret ved betaling av foreldet gjeld. Tvert imot må det antas at dersom Høyesterett ønsket å rokke ved dette utgangspunktet, hadde de sagt dette eksplisitt, eller i det minste kritisert den tilnærmingen som fulgte av henvisningen til Arnholm. Når de i stedet begrunnet fortsatt tilbakes $\varnothing$ kningsrett i forbehold, må det anses som en anerkjennelse

\footnotetext{
${ }^{123}$ Se bl.a. Bergsåker (2015) side 274 og Augdahl (1978) side 401.

${ }^{124}$ Arnholm (1939) side 176.

125 Ibid. side 177.

126 Se f.eks. Code des obligations artikkel 63 annet ledd som eksplisitt unntar foreldet gjeld og «moralske forpliktelser» fra tilbakesøkning. Se også Code civil artikkel 1302 annet ledd som gjør unntak for «obligations naturelles» (obligatio naturalis).

127 Zimmermann (1990) side 7.

${ }^{128}$ Rt. 2012 s. 722 (premiss 49), med henvisning til Arnholm.
} 
av den hovedregelen som er lagt til grunn i teorien, slik at det kreves særlige grunner for at tilbakesøkningskrav ved foreldet gjeld skal kunne føre frem. Imidlertid kan det tenkes at dommen åpner døren for at også andre særlige grunner enn forbehold kan begrunne tilbakesøkningskrav ved betaling av foreldet gjeld.

Dommen sier ikke noe om hvorfor betaling av foreldet gjeld i utgangspunktet ikke gir grunnlag for tilbakes $\varnothing$ kning. Svaret må søkes i virkningene av foreldelse. Det følger av foreldelsesloven $\S 24$ at «[v]ed foreldelse taper fordringshaveren sin rett til oppfyllelse.» Det er altså retten til, eller kravet på, ${ }^{129}$ oppfyllelse som tapes: Man kan ikke lenger få dom på oppfyllelse av en foreldet fordring. Derimot innebærer det ikke at man helt kan se bort fra at fordringen har eksistert. ${ }^{130}$ Den moralske forpliktelsen til å betale vil kunne bestå og dermed utgjøre et grunnlag for betalingen. Selv om betalingen altså ikke skjer til oppfyllelse av en rettslig forpliktelse, medfører den underliggende moralske forpliktelsen at der man har oppfylt, kan man i utgangspunktet ikke kreve pengene tilbake. På samme måte som i de rettssystemer som eksplisitt gjør unntak for rett til tilbakebetaling ved betaling av foreldet gjeld, bør man også i norsk rett anse dette som et unntak.

Alternativet måtte være å anse tilbakesøkning som utelukket fordi betalingen skulle utgjøre en selvstendig rettsgrunn, se punkt 4.4. Imidlertid har det vært lagt til grunn at tilbakesøkning av betaling av foreldet gjeld også er utelukket der betaleren ikke visste at fordringen var foreldet på betalingstidspunktet. ${ }^{131}$ Slike tilfeller lar seg vanskelig forene med at betalingen utgjør en rettslig disposisjon fordi betaleren har ment å betale uavhengig av om det forelå en rettslig forpliktelse eller ei. Har betaleren vært i en villfarelse, vil dette nettopp være et argument for at han ikke hadde vilje til å disponere dersom han hadde visst at han ikke var rettslig forpliktet.

\subsection{Der betalingen utgjør en selvstendig rettslig disposisjon}

\subsubsection{Innledning}

Det jeg skal se på nedenfor, er de tilfeller hvor det ikke foreligger en foregående rettslig forpliktelse, men man likevel anser betalingen for å ha en rettsgrunn fordi betalingen i seg selv utgjør en rettslig disposisjon.

I norsk rett har det vært vanlig å anse betalinger som faktiske handlinger og ikke som rettslige disposisjoner. Spørsmålet om betalingen kan utgjøre en selvstendig rettsgrunn, som inngangsvilkår for tilbakesøkning, har ikke vært viet særlig oppmerksomhet hverken i teori eller praksis. Tanken er derimot ikke ny. I sin avhandling bygget Arnholm på en tanke om at betalingen

\footnotetext{
${ }^{129}$ Ot.prp. nr. 38 (1977-1978) side 78.

${ }^{130}$ Kjørven (2011) side 537.

${ }^{131}$ Kjønstad (1983) side 131.
} 
hadde karakter av en «godkjennelse» av en forpliktelse til å betale. ${ }^{132}$ Men for Arnholm var en slik tanke om at betalingen generelt innebar en godkjennelse, å anse for et tungtveiende moment ved helhetsvurderingen. ${ }^{133}$ Selv om det til stadighet vises til «oppgjørshensynet», finner jeg ikke støtte i nyere praksis for at betalingshandlingen i seg selv skal være et avgjørende moment i helhetsvurderingen. Særlig synes Rt. 1988 s. 556 å gå imot Arnholms syn om at en betaler som mener å ha innsigelser, har en plikt til å ta et standpunkt ved betalingstidspunktet. ${ }^{134}$ Selv om et generelt hensyn ved helhetsvurderingen om at betalingen er en godkjennelse av en betalingsforpliktelse ikke kan opprettholdes, kan det tenkes at man vil anse tilbakesøkning for utelukket fordi at man i det konkrete tilfellet ikke stod overfor en betaling uten rettsgrunn overhodet.

\subsubsection{Grunnlag i norsk rett}

I NJA 2011 s. 2011 uttaler Högsta domstolen at det avgjørende for tilbakesøkning ved feilbetaling er «om betalningen har skett utan rättsgrund och att betalningen inte ugör en disposition, dvs. en betalning där den betalande frivilligt väljer att betala oavsett om betalningsskyldighet faktisk föreligger». ${ }^{135}$ Det sitatet viser til, er at betalingen i seg selv kan utgjøre en viljeserklæring og dermed en rettsgrunn for betalingen.

Selv om man fra norsk høyesterettspraksis ikke har like klare uttalelser som fra Högsta domstolen, mener jeg at et tilsvarende vilkår kan utledes av Rt. 2004 s. 782 . I dommen hadde A innfridd sin tidligere samboer Bs utleggsgjeld til banken i deres tidligere felles eiendom, i forbindelse med salg. A krevde deretter beløpet tilbakebetalt fra banken. Høyesterett erkjente at A nok hadde «følt seg» $\mathrm{i}$ en tvangssituasjon, hvor hun opplevde seg tvunget til å innfri gjelden siden eiendommen allerede var solgt. ${ }^{136}$ Men Høyesterett kunne ikke se at betalingen var følge av en villfarelse fra As side om egen forpliktelse. Banken hadde forholdt seg til B, og A hadde, vel å merke i en situasjon med få valgmuligheter, valgt å innfri Bs gjeld for å kunne overdra eiendommen heftelsesfritt. Det Høyesterett uttrykkelig bygget på, var at betalingen «ikke var resultatet av noen misforståelse fra As side», og at det derfor ikke var aktuelt å vurdere tilbakesøkning etter «reglene om condictio indebiti». ${ }^{137}$ Ved første $\varnothing y e k a s t ~ k a n$ dette fremstå som en bekreftelse på at det foreligger et vilkår om villfarelse, se punkt 4.5. Ved nærmere analyse, bør utsagnet likevel sorteres under vilkåret om «fravær av rettsgrunn».

\footnotetext{
132 Arnholm (1939) side 168 flg.

${ }^{133}$ Ibid. side $196 \mathrm{flg}$.

${ }^{134}$ Ibid. side 169.

${ }^{135}$ NJA 2011 s. 739 (domskälen avsnitt 8) (min kursivering).

${ }^{136}$ Rt. 2004 s. 782 (premiss 30).

${ }^{137}$ Ibid. (premiss 35).
} 
For det første er det klart at det forelå en rettsgrunn for betaling til banken, men at forpliktelsen ikke påhvilte A. Situasjonen er altså den samme som i andre dommer om feil betaler. Utgangspunktet vil her være at man står over for en betaling uten rettsgrunn, og at man kan vurdere om tilbakesøkning bør finne sted, slik som Høyesterett har gjort i de andre dommene nevnt under punkt 4.3.4. Når jeg her ser spørsmålet om fravær av villfarelse som et spørsmål om rettsgrunn, er det fordi at da ingen villfarelse om egen forpliktelse forelå, må betalingen til banken anses som en frivillig betaling av annens gjeld, og således utgjøre en rettslig disposisjon. Sagt med Högsta domstolens ord, står man overfor «en betalning där den betalande frivilligt väljer att betala oavsett om betalningsskyldighet faktisk föreligger». ${ }^{138}$ Dermed står man ikke lenger overfor en betaling uten rettsgrunn, men en selvstendig rettslig disposisjon fra A.

Ut fra Høyesteretts vurdering av faktum i saken forelå det en rettsgrunn for betalingen. Dette ville stilt seg annerledes dersom Høyesterett hadde kommet til at A enten hadde vært i en tvangssituasjon som banken var skyld $i$, eller at hun hadde vært $i$ en villfarelse om at betalingsplikten faktisk hvilte på henne. Dette fant ikke Høyesterett bevist. Tvert imot erkjente de at hun måtte ha «følt seg i en tvangssituasjon», men at dette var en «konsekvens av den salgsavtalen som var inngått», altså en situasjon hun selv hadde satt seg i. ${ }^{139}$ Noen villfarelse var det som nevnt heller ikke snakk om.

På bakgrunn av denne vurderingen av faktum var det klart at det ikke kunne bli tale om noen ulovfestet tilbakesøkning. Når Høyesterett begrunner at tilbakesøkning ikke kan komme på tale med at det ikke forelå villfarelse, bryter dette med nyere rettspraksis som har innrømmet tilbakesøkning på tross av fravær av villfarelse, se punkt 4.5. I stedet burde Høyesterett vist til at der man frivillig betaler noe man vet man ikke skylder, kan betalingen utgjøre en selvstendig rettslig disposisjon. Det var denne rettsgrunnen, og ikke fraværet av villfarelse i seg selv, som medførte at tilbakesøkning var utelukket. Villfarelsen er således bare et moment ved vurderingen om betalingen skal anses som en rettslig bindende disposisjon.

Denne forståelsen av Rt. 2004 s. 738 er også egnet til å forklare hvorfor Høyesterett kunne komme til et motsatt resultat i Rt. 1998 s. 989. ${ }^{140}$ Det sentrale her er at også denne dommen gjaldt innfrielse av andres gjeld hvor betaleren $i k k e$ hadde vært i villfarelse om å være forpliktet eller i en tvangssituasjon. Ved første øyekast ville man derfor tro at resultatene i dommene ville bli det samme, eller at Høyesterett i Rt. 2004 s. 782 i det minste ville kommentere på hvorfor man kom til et annet resultat. Men dette skjedde altså ikke.

\footnotetext{
${ }^{138}$ NJA 2011 s. 739 (domskälen avsnitt 8).

${ }^{139}$ Rt. 2004 s. 782 (premiss 30).

${ }^{140}$ Sakens faktum er omtalt i punkt 4.3.4.
} 
Som i dommen fra 2004 var det anført at betaleren var klar over at det ikke forelå en forpliktelse, slik at man stod overfor en frivilling betaling. Høyesterett gikk ikke inn på krav til eventuell villfarelse, men uttalte at betaleren klart nok var $\mathrm{i}$ «villfarelse om et forhold som var helt avgjørende for om han skulle gi stoppordre [avbryte betalingen]». ${ }^{141}$ Det Høyesterett legger til grunn, er altså at dersom banken hadde vært kjent med de faktiske forhold, så ville de ikke betalt. Og hadde de likevel betalt, måtte de nok her trolig tatt til takke med et regresskrav mot Fearnley \& Eger. Et poeng her, som Høyesterett ikke kommenterer, er at banken overhodet ikke kan tenkes å ha hatt noen selvstendig motivasjon for å innfri Fearnley \& Egers gjeld. De var ikke kausjonister dersom rederiet viste seg betalingsudyktige, og det var heller ikke anført noen andre grunner som kunne tilsi at banken hadde en selvstendig motivasjon for å oppfylle rederiets forpliktelse. Det er dermed vanskelig å se for seg at banken hadde ment å tre inn i rederiets forpliktelse. En slik selvstendig motivasjon forelå derimot i saken fra 2004, da det var i As interesse å få solgt eiendommen heftelsesfritt.

Når man hverken har ansett banken for å ha tredd inn i rederiets forpliktelse eller for å ha hatt en selvstendig motivasjon for å betale, kunne ikke bankens betaling utgjøre en rettslig disposisjon. Da betalingen hverken var oppfyllelse av en foregående forpliktelse eller utgjorde en selvstendig rettslig disposisjon, forelå det ingen rettsgrunn for betalingen. Dermed stod man overfor en feilbetaling, og det måtte være anledning til tilbakesøkning etter en helhetsvurdering. Det er også det Høyesterett gjorde.

Før Høyesterett gikk over til helhetsvurderingen uttalte de:

«Det kan hende at dette tilfellet ligger i ytterkanten av det som anses som en tradisjonell condictio indebitisituasjon. Om det er treffende å si at det her foreligger et indebitum, avhenger - slik jeg ser det - av hvilken synsvinkel som anlegges. Den terminologi som anvendes, kan imidlertid ikke være avgjørende for det materielle spørsmål.» ${ }^{142}$

Denne uttalelsen er uheldig, da den stiller spørsmål ved om det i det hele tatt er krav om at det foreligger et «indebitum» for at man skal kunne gå videre til å drøfte om tilbakesøkning er rimelig. Et «indebitum» kan oversettes med «ikke-skyld» ${ }^{143}$ og er ment dekket med begrepet «fravær av rettsgrunn». Høyesterett bør ikke her si seg fornøyd med å uttale at dette er et spørsmål om «synsvinkelen som anlegges», men ta ansvar for å tolke og få frem hvilken

\footnotetext{
${ }^{141}$ Rt. 1998 s. 989 (side 999).

142 Ibid.

${ }^{143}$ Zimmermann beskriver begrepet som «a preformance that was never owed to him and that he therefore has no right to keep», se Zimmermann (1990) side 834.
} 
synsvinkel de som prejudikatsdomstol legger til grunn. Når det er sagt, innebærer ikke uttalelsen noen motstrid med det syn som forfektes her: Ut fra den «synsvinkel» som er lagt til grunn ovenfor, så foreligger det her et indebitum, og det er derfor ulovfestet tilbakesøkning i det hele tatt kan komme på tale. Det Høyesterett her burde sagt, var at det ikke forelå foregående forpliktelse for banken, og man ikke fant det sannsynliggjort at banken hadde ment å tre inn i eller påta seg rederiets forpliktelse. Dermed forelå det ingen rettsgrunn for betalingen. Det forelå altså et «indebitum».

Denne uheldige uttalelsen har i senere praksis blitt tatt til inntekt for at det ikke kan bygges på «eit formelt condictio indebitiomgrep». ${ }^{144}$ Denne forståelsen er uheldig, da den har frarøvet partene i feilbetalingssakene forutberegneligheten. En slik forståelse er dessuten helt unødvendig: Både i Rt. 2001 s. 1580 og i Rt. 2010 s. 816 kunne man, ut fra den vurdering av saksforholdet. Høyesterett la til grunn, kommet til samme resultat dersom man hadde bygget på at det forelå et krav om «indebitum», eller fravær av rettsgrunn som jeg har valgt som terminologi. At borettslaget overhode ikke hadde noen forpliktelse i Rt. 2001 s. 1580, medførte åpenbart at betalingen savnet rettsgrunn hva gjaldt forholdet mellom borettslaget og mottageren. Og at det i Rt. 2010 s. 816 var krevet mer i avgift enn man hadde krav på etter endelig fastsettelse, medførte også at man for det overskytende beløpet savnet rettsgrunn for betalingen. Uavhengig av Høyesteretts formuleringer i alle disse tre sakene, er det som faktisk gjфres at man tar avstand fra et absolutt krav om villfarelse. Dette kan man fint gjøre uten å så tvil om kravet om fravær av rettsgrunn. Den uklarhet som finnes i rettspraksis etter 1998, synes å skyldes at man har foretatt en sammenblanding av «indebitum» og villfarelse.

\subsubsection{I hvilke tilfeller utgjør betalingen en rettslig disposisjon?}

\subsubsection{Presumpsjoner om rettslig disposisjon}

Ovenfor er det gjort rede for at i tillegg til at det ikke har foreligget en foregående rettslig forpliktelse for betalingen, må betalingen heller ikke utgjøre en rettslig disposisjon. Da oppstår spørsmålet om når en betaling utgjør en rettslig disposisjon, og ikke bare en faktisk handling som man ikke kan slutte binding fra. Spørsmålet blir en variant av det man ellers kjenner fra avtaleretten om hva som skal til for å anse en avtale for inngått. Dette må avgjøres ut fra et spørsmål om partene har fått berettigede forventninger om binding, som igjen må avgjøres etter en helhetsvurdering. ${ }^{145}$ Noen utgangspunkter skal likevel trekkes opp nedenfor.

\footnotetext{
${ }^{144}$ Se Rt. 2001 s. 1580 (side 1586). Dette er gjentatt i Rt. 2010 s. 816 (premiss 60).

${ }^{145}$ Se bl.a. HR-2017-971-A (premiss 41 flg.).
} 
Fra den rettspraksis som er gjennomgått i punkt 4.3.1, ser vi at det er særlig i to situasjoner hvor man vil kunne komme i tvil om betalingen utgjør en selvstendig rettslig disposisjon. For det første har vi vist at ved betaling av andres gjeld vil det ofte være nærliggende å tro at betalingen er ment som en inntreden i den annens forpliktelse. Motivasjonen vil her kunne være en ivaretagelse av rette debitors interesser, eller, som i Rt. 2004 s. 782, at man har egne interesser $\mathrm{i}$ at rette debitor betaler sin gjeld. Den andre situasjonen hvor spørsmålet kommer på spissen, er ved utilstrekkelig rettsgrunn. Der det allerede foreligger en forpliktelse mellom partene, men denne er overoppfylt, vil det kunne bli spørsmål om overoppfyllelsen skyldes en ettergivelse av krav, et forlik eller innebærer en stilltiende endring av avtalen.

Står man overfor komplett fravær av rettsgrunn, vil det nok sjelden bli spørsmål om betalingen utgjør en rettslig disposisjon. I alminnelighet betaler man ikke det man ikke skylder, og noen motivasjon annet enn foregående rettslig forpliktelse, for eksempel et ønske om å dekke andres gjeld, forlike et krav eller lignende, er mindre sannsynlig i disse tilfellene enn i tilfellene nevnt $\mathrm{i}$ forrige avsnitt. Dersom mottageren mener at betalingen er en disposisjon, får det være opp til ham å sannsynliggjøre det. Men foreligger det en relasjon mellom partene, kan det være lettere å sannsynliggjøre at betalingen er en disposisjon.

Det som er sagt om komplett fravær av rettsgrunn, vil gjelde med minst samme styrke for betaling til feil mottager. Ved komplett fravær av rettsgrunn må det sannsynliggjøres at A har ment å berike B selv om han ikke var forpliktet til det. I tilfellene hvor det er betalt til feil mottager, må det sannsynliggjøres at A har ment å berike B, i tillegg til å oppfylle sin forpliktelse overfor $\mathrm{C}$, som er rette kreditor for kravet.

De presumpsjoner jeg har gjort ovenfor, har nært slektskap med reguleringen av tilbakesøkning i fransk rett, jf. Code civil artikkel $1302 \mathrm{flg}$. Ser man på tilfeller hvor det overhodet ikke foreligger noen forpliktelse, eller man har betalt til feil mottager, er hovedregelen at pengene skal føres tilbake. Det foreligger ikke noe vilkår om villfarelse. Unntaket er for frivillige betalinger, men her er presumpsjonen negativ: Det er mottager som må bevise at betalingen eventuelt var ment som en gavedisposisjon. ${ }^{146}$ Derimot er det ved innfrielse av andres gjeld et tilleggsvilkår om tvang eller feiltagelse. ${ }^{147}$ Foreligger ikke tvang eller feiltagelse, legger man til grunn at betalingen var ment å utgjøre en rettslig disposisjon, og tilbakesøkning er derfor utelukket. ${ }^{148}$

\subsubsection{Vurderingstema for spørsmålet om rettslig disposisjon}

Som vist ovenfor er det i de tilfellene hvor det er uklart hva som er motivasjonen for betalingen, at spørsmålet om selvstendig rettslig disposisjon kommer på spissen. Det man dypest sett søker svar på, er hvorvidt betaleren mente å berike mottageren uavhengig av rettslig plikt til å betale. Som kjent er det vanskelig å trenge inn i folks hoder og finne ut av hva de mener.

\footnotetext{
146 Bénabent (2017) side 361-362.

${ }^{147}$ Ibid. side 363.

148 Terré (2005) side 1011.
} 
Av denne grunn kan man ikke her komme lengre enn å trekke frem noen momenter og presumpsjoner som til syvende sist må vurderes konkret. Nedenfor vil jeg særlig trekke frem tre momenter av betydning for vurderingen: frivillighet, villfarelse og alternativ motivasjon.

I NJA 2011 s. 739 definerer Högsta domstolen vurderingstemaet for hvorvidt det foreligger en rettslig disposisjon, til å være hvorvidt «den betalande frivilligt väljer att betala oavsett om betalningsskyldighet faktisk föreligger». Lignende formuleringer nyttes i Draft Common Frame of Reference med hensyn til uberettiget berikelse, hvor det heter at berikelsen ikke er uberettiget dersom «the disadvantaged person consented freely and without error to the disadvantage». ${ }^{149}$

Med utgangspunkt i Rt. 2004 s. 782 må vi legge til grunn at dersom man frivillig har oppfylt en forpliktelse som man visste man ikke var forpliktet til å oppfylle, foreligger en presumpsjon for at man har ment at betalingen skal utgjøre en selvstendig rettslig disposisjon. Dette utgangspunktet bygger på erkjennelsen av at folk normalt ikke betaler noe de ikke skylder. Hvor grensen for «frivillighet» skal trekkes, må avklares i praksis, men Rt. 2004 s. 782 gir en viss veiledning. Selv om man har «følt seg» $\mathrm{i}$ en tvangssituasjon, er betalingen frivillig dersom man selv anses å ha forårsaket den tvangssituasjonen man er i. Det er den eksterne tvangen som medfører at en betaling ikke utgjør en rettslig disposisjon. En eventuell kritikk av avgjørelsen fra 2004 må derfor begrunnes i at man la for stor vekt på at betaleren selv hadde satt seg i en vanskelig situasjon, og for lite vekt på at banken eller andre hadde medvirket til den situasjonen som oppstod.

Selv om betalingen i og for seg er frivillig, kan dette ikke tillegges vekt ved vurderingen av rettslig disposisjon dersom den frivillige betalingen skyldes en villfarelse. Villfarelsen kan relatere seg både til forpliktelsens eksistens og til faktiske forhold. I Rt. 1998 s. 989 medførte villfarelse om faktiske forhold at man ikke anså betalingen for å utgjøre en selvstendig rettslig disposisjon. Felles for villfarelse om plikt og faktiske forhold er at begge typer villfarelse kan påvirke betalerens motivasjon for å betale. I Rt. 1998 s. 989 var betalingen motivert av å oppfylle et oppdrag mot en forventning om inndekning fra banken. Da denne forventningen ikke slo til, forelå ingen motivasjon for betalingen. Noen alternativ motivasjon for betalingen kunne ikke sannsynliggjøres. Til sammenligning hadde betaleren i Rt. 2004 s. 782 en selvstendig motivasjon for å innfri ekskjærestens gjeld: Hadde hun ikke innfridd gjelden, ville hun ikke kunnet overført eiendommen heftelsesfritt, og hun hadde vært i mislighold overfor kjøper.

\footnotetext{
${ }^{149}$ Draft Common Frame of Reference punkt VII:2:101 (1) b.
} 
At selvstendig motivasjon for betalingen er et moment ved vurderingen av om betalingen skal utgjøre en rettslig bindende disposisjon, støttes av et mindretallsvotum fra 1934. I dommen fant mindretallet at det forelå rettsgrunn for betalingen, og fant dermed ikke grunn til tilbakesøkning. Annenvoterende uttalte at:

«Naar styret tross denne tvil har valgt at betale, da faar det ogsa staa ved det, selv om det bakefter naatte vise sig at det kunde ha sluppet billigere. Ved at betale efter Narvikbankens opgjør, opnaadde ogsaa Ankenes-banken straks at kunne faa skjøte paa den kjøpte eiendom og straks at faa disponere over den, hvilket var av betydning for den. Banken synes saaledes at ha hatt et motiv for sin betaling og denne kan i virkeligheten ikke sies at være skjedd «sine causa».» 150

Den rettskildemessige vekten av en dissens fra 1934 er åpenbart begrenset, men begrunnelsen kan likefullt trekkes inn som et argument til støtte for den systematikk man kan utlede fra dommene fra 2004 og 1998. Dissensen gir uttrykk for en annen forståelse av faktum enn flertallet, men det fremgår derimot ikke at flertallet bygget på en annen rettslig forståelse. Mindretallets uttalelse ovenfor er godt forenelig med det resultat Høyesterett kom til i Rt. 2004 s. 782: Der betaleren synes å ha hatt et motiv for betalingen, selv om det ikke forelå en rettslig forpliktelse, vil dette motivet være et argument for at betalingen bør anses som en selvstendig rettslig disposisjon.

Dette motivasjonsresonnementet kan også trekkes inn der man står overfor utilstrekkelige rettsgrunner. Har man for eksempel etter en lengre diskusjon om hva som er riktig beløp for en kontraktsgjenstand, betalt det mottager krever, vil det være nærliggende å presumere at betalingen innebærer en aksept av det beløpet mottageren krevde, altså en selvstendig rettslig disposisjon. Men her er det altså ikke mer enn en presumpsjon, og denne vil skifte dersom betaleren kan vise at man ikke stod overfor en frivillig betaling. Her er Rt. 1988 s. 556 egnet til å belyse. Faktum i dommen er nevnt under punkt 4.3.4. I saken fremmet fra en bank krav om tilbakebetaling fra en obligasjonshaver, hvis krav banken hadde innfridd i strid med en prioritetsavtale mellom partene. Høyesterett sier ikke eksplisitt hvilket grunnlag for tilbakebetaling de bygger på, men viser til byrettens begrunnelse, som igjen viser til Arnholm og Augdahl.

På de sidene det er henvist til, omtaler Augdahl en situasjon hvor det er ytet uten forpliktelse, ${ }^{151}$ og hvor yteren vet han er uforpliktet, men oppfyller under press. Arnholm på sin side omtaler en situasjon hvor yteren mener seg uforpliktet, men ikke finner å ha bevisene for å motsette seg kravet. ${ }^{152}$ I begge fremstillingene gjelder det

\footnotetext{
${ }^{150}$ Rt. 1934 s. 400 (side 404).

151 Augdahl (1972) side 395.

${ }^{152}$ Arnholm (1966) side 156.
} 
tilbakesøkningskrav og ikke erstatningskrav. I Augdahls fremstilling virker det som at man ser på dette som et selvstendig grunnlag på siden av condictio indebiti, mens det i Arnholms fremstilling fremstår som et særtilfelle under condictio indebiti.

Legger man til grunn at tilbakesøkningskravet kunne bygges på ugyldighet, må vi forutsette at man så betalingen som en selvstendig rettslig disposisjon. Hadde betalingen ikke vært en rettslig disposisjon, kunne man ikke bygget direkte på ugyldighetsreglene, som får anvendelse på viljeserklæringer og ikke faktiske handlinger, hvilket betalinger stort sett er. Man ser dermed betalingen som en rettslig disposisjon, men denne disposisjonen er ugyldig fordi den er gjort under tvang, jf. avtaleloven $\S 33$. Legger man i stedet til grunn at tilbakes økningskravet kunne bygges på ulovfestede regler, må man anse det som en betaling som savnet rettsgrunn, da banken etter prioritetsavtalen ikke, ennå, var forpliktet til å betale. I så fall ser vi heller ikke betalingen som en rettslig disposisjon, da betalingen er ytet under tvang.

Der man faller innenfor en av ugyldighetsgrunnene i avtaleloven, er tilnærmingen som illustrert ovenfor likegyldig: Enten ser man det som en viljeserklæring slik at ugyldighetsreglene kommer direkte til anvendelse, eller så kan man anvende ugyldighetsreglene analogisk på den faktiske betalingshandlingen, jf. HR-2016-2491-A. I disse tilfellene gir ugyldighetsreglene større sikkerhet for tilbakebetalingskravet enn ulovfestede regler om tilbakes $\varnothing$ kning av feilbetalinger. Men i tilfeller hvor betaleren har vært utsatt for press eller påvirkning som ikke når opp til terskelen i ugyldighetsbestemmelsene, blir det avgjørende hvorvidt man anser betalingen som en rettslig disposisjon eller ikke. Av denne grunn bør man derfor i de tilfeller hvor det kan vises til at betalingen ikke har vært frivillig, bygge på at man ikke har ment å forplikte seg rettslig, slik at man står overfor en alminnelig feilbetaling som savner rettsgrunn. I fransk rett er en slik tilnærming nå lovfestet for tilfellene av betaling av annens gjeld. ${ }^{153}$

\subsubsection{Oppsummering}

Ovenfor i punkt 4.4.2 så vi at man fra rettspraksis kan utlede et vilkår om at betalingen ikke i seg selv må utgjøre en selvstendig rettslig disposisjon. Sammen med vilkåret om at det ikke må foreligge en foregående forpliktelse, utgjør dette et grunnvilkår for tilbakesøkning om fravar av rettsgrunn.

Enkelte momenter for vurderingstemaet for spørsmålet om betalingen må sies å utgjøre en selvstendig rettslig disposisjon, er gjennomgått i punkt 4.4.3. Utgangspunktet er at betalinger er faktiske handlinger. Dermed hviler bevisbyrden på den som hevder at betalingen utgjør en rettslig disposisjon. Det sentrale spørsmålet er hvorvidt betaleren mente å berike mottageren uavhengig av rettslig plikt til å betale. For mottageren blir det da å sannsynliggjøre en alterna-

\footnotetext{
${ }^{153}$ Code civil artikkel 1302-2 første ledd.
} 
tiv motivasjon for betalingen. Frivillighet og fravær av villfarelse vil gjøre det lettere å komme til at slik alternativ motivasjon foreligger; tvang og villfarelse leder oss mot motsatt slutning. Der betaleren har en relasjon til mottageren eller rette debitor, vil det være lettere å argumentere for at betaleren hadde en selvstendig motivasjon for betalingen, for eksempel gave, forlik, ettergivelse eller lignende. Der det overhodet ikke har vært noe mellomværende mellom partene, vil det derimot være vanskelig å sannsynliggjøre at betalingen var ment som en disposisjon: Den som vil overbevise dommeren om at betaler hadde gavehensikt overfor en vilt fremmed, har nok en tung jobb foran seg.

\subsection{Feilens art}

\subsubsection{Innledning}

Tradisjonelt har det for tilbakesøkning på grunnlag om condictio indebiti vært vilkår om en form for villfarelse. Som vi så i kapittel 3, opererer ikke lenger Høyesterett med noe krav om villfarelse for at tilbakesøkning skal være aktuelt. Det som skal undersøkes nedenfor, er derfor hva slags typer feil som har foranlediget betalingen i de saker som har gått for Høyesterett, og hvorvidt man på bakgrunn av dette kan oppstille et grunnvilkår om noen slags feil.

I det følgende skiller jeg mellom begrepene villfarelse og feil. Med villfarelse sikter jeg til villfarelse om egen forpliktelse. Denne type villfarelse gir inntrykk av at det er partens subjektive forståelse som er avgjørende. Når jeg i stedet bruker begrepet feil, er dette for å få med tilfellene hvor man objektivt sett står ovenfor en betaling uten rettsgrunn, og feilen relaterer seg til at det rent faktisk ble betalt. Dermed inkluderer tilfeller hvor man har tastet eller regnet feil, har betalt til feil mottager og lignende. I disse tilfellene er feilen ikke avhengig av betalerens subjektive oppfatninger om betalingsskyld.

\subsubsection{Villfarelse om forpliktelsens eksistens og omfang}

De klassiske condictio indebiti-tilfellene gjelder villfarelse, enten om forpliktelsens eksistens eller omfang. ${ }^{154}$ I Rt. 1997 s. 1029 betalte forsikringsselskapet i den villfarelse at det var snakk om skader som var inntrådt mens de var forsikrer for rederiet. Tilsvarende var forsikringsselskapene i Rt. 1995 s. 1641 og i Rt. 1985 s. 290 i villfarelse om sin forpliktelse til å betale forsikring, da de ikke visste, eller kunne bevise, at sikrede selv hadde senket skipene. Også i Rt. 1979 s. 69 kan nok kjøper sies å ha vært i villfarelse om sin forpliktelse til å betale kredittyterens provisjon fra selger. Av ovennevnte er i alle fall klart at ved villfarelse om selve forpliktelsen kan tilbakes $\varnothing$ kning kreves.

\subsubsection{Andre typer feil}

I de fleste tilfellene hvor tilbakesøkning har blitt vurdert, har det imidlertid ikke foreligget noe som kan kalles villfarelse. I Rt. 2012 s. 722 mente betaleren seg fra første stund uforpliktet,

\footnotetext{
${ }^{154}$ Rt. 2001 s. 1580 (side 1586).
} 
og tok endog forbehold. Feilen lå her i at betaling ikke skulle ha vært krevet, altså i at rettsgrunnen ikke forelå. Noe villfarelse kan det ikke være snakk om. I Rt. 2010 s. 816 sier Høyesterett rett ut at det «ikkje [er] tale om betaling grunna ei villfaring.» ${ }^{155}$ Feilen lå i at de midlertidige utregningene av avgift ikke stemte med det man til slutt hadde lagt til grunn i de endelige vedtakene. I Rt. 2008 s. 1510, som gjaldt uriktig ilignet arveavgift, hadde betaler fra første stund protestert og var således ikke i noen villfarelse. Feilen lå her også i selve avgiftsvedtaket. Også i Rt. 1997 s. 1210 hadde betalerne protestert fra første stund. Dermed forelå det heller ikke her noen villfarelse. Heller ikke i Rt. 1988 s. 556 kan det sies å ha foreligget noen villfarelse på betalerens hånd. Banken var fra første stund uenige i kravet, men valgte å betale for å kunne få solgt de pantsatte seksjonene heftelsesfritt. Et fellestrekk ved disse dommene var imidlertid at betaleren hadde ytet $\mathrm{i}$ en tvangssituasjon av et eller annet slag.

I Rt. 1998 s. 989 uttalte Høyesterett at betaleren hadde vært «i villfarelse om et forhold som var helt avgjørende for om han skulle gi stoppordre til VSP.» Det betaleren var i villfarelse om, var at det allerede var på det rene at deres kunde mest sannsynlig ikke hadde midler til inndekning for lånebeløpene. Betalingshandlingen var dermed følge av en villfarelse om de faktiske forhold, men ikke av en villfarelse om rettslig forpliktelser.

\subsubsection{Handlinger som vanskelig kan sies å bero på en feil}

En sak som skiller seg ut blant sakene hvor man har bygget på en ulovfestet tilbakesøkningsadgang, er Rt. 2001 s. 1580. Saken er omtalt ovenfor under punkt 4.3.4, og som nevnt blitt kritisert i teorien for å anvende condictio indebiti i stedet for reglene om godtroerverv. Flertallet anså spørsmålet til å gjelde ulovfestet tilbakesøkning, da borettslaget ble ansett som betaler. Men selv med denne forutsetning lagt til grunn er det vanskelig i denne saken å se at det foreligger noen som helst feil fra borettslagets side: Borettslaget var komplett uvitende om at betalingen ble foretatt. Den eneste «feilen»var at forretningsføreren misbrukte sin fullmakt. Direkte skyldtes feilen altså hverken en objektiv eller subjektiv feil fra betalers side, men eventuelt at noen som hadde disposisjonsfullmakt fra borettslaget misbrukte sin fullmakt. Enklere vil være å si at «feilen» lå i at det ble betalt overhodet, uavhengig av hvilken rolle betaleren hadde i denne feilen. Da det her overhodet ikke var disponert fra borettslagets side, var det imidlertid uaktuelt å anse betalingen for en selvstendig rettslig disposisjon, slik at det ikke var noe behov å kunne vise til en bestemt «feil» som hadde foranlediget betalingen.

\subsubsection{Oppsummering}

Den rettspraksis som er vist til ovenfor, illustrerer at en rekke «feil»kan medføre at krav om tilbakesøkning kan føre frem. Noe krav om villfarelse er det ikke lenger grunn til å stille opp

${ }^{155}$ Rt. 2010 s. 816 (premiss 63). 
som et grunnvilkår for tilbakesøkning. Dommene i punkt 4.4.2 og 4.4.3 viser at der selve betalingen savner rettsgrunn, er det rettere å si at «feilen» ligger i det faktum at det var betalt noe man ikke var forpliktet til. Som Arnholm fremholdt, var hensikten med å operere med et vilkår om villfarelse å avgrense mot de tilfellene hvor betaleren var klar over både de faktiske og rettslige forhold, men likevel valgte å betale frivillig. ${ }^{156}$ Men dersom tilbakesøkning allerede er utelukket for tilfeller hvor betalingen utgjør en selvstendig rettslig disposisjon, er det ikke grunn til å oppstille ytterligere krav om «feil» enn at det er betalt uten rettsgrunn. Dette illustreres ved Rt. 2001 s. 1580, hvor det var klart at betalingen ikke kunne utgjøre noen rettslig disposisjon fra betalerens side. Dermed hadde man ikke behov for å vise til at det forelå noen konkret «feil». På denne bakgrunn kan det ikke oppstilles et generelt vilkår om «feil», utover de tilfellene hvor man ellers må legge til grunn at betalingen utgjør en selvstendig rettslig disposisjon. For denne vurderingen vil fravær av feil og press nettopp utgjøre et forhold som tilsier at betaleren har disponert rettslig.

\subsection{Andre vilkår}

\subsubsection{Forholdet til andre rettsgrunnlag}

I enkelte nyere saker har det kommet uttalelser som kan tyde på at ulovfestet tilbakesøkning må vike der andre rettsgrunnlag er aktuelle. I Rt. 2013 s. 1665, som gjaldt spørsmål om foreldelse av tilbakesøkningskrav, uttalte Høyesterett at «læren om condictio indebiti må her vike for det mer spesielle grunnlag for tilbakebetaling». ${ }^{157}$ Den konkrete tvisten dreiet seg om tilbakesøkning av EØS-stridig statsstøtte. ${ }^{158}$

Også i Rt. 2012 s. 1444 var det spørsmål om foreldelse av tilbakesøkningskrav, men denne gangen på trygderettens område. Høyesterett uttalte, med henvisning til forarbeidene, at de hadde «vanskelig for å forstå disse drøftelsene på annen måte enn at bestemmelsen [trygdeloven $§ 22-15]$ heretter skal være uttømmende for så vidt gjaldt adgangen til å kreve tilbakebetaling fra trygdemottakere som hadde vært i aktsom god tro.» ${ }^{159}$

At det aktuelle grunnlaget for tilbakes $\varnothing$ kning der det finnes spesiallovgivning, fortrinnsvis bør være denne og ikke ulovfestet rett, er ikke overraskende. Derimot trekker begge de to ovennevnte dommene i retning av at det heller ikke kan være adgang til subsidiære krav bygget på ulovfestet tilbakesøkning, der spørsmålet i første omgang er regulert i spesiallovgivningen. I Rt. 2012 s. 1444 følger dette av en konkret vurdering av tilbakesøkningsregelen i folketrygd-

\footnotetext{
156 Arnholm (1939) side 180.

${ }^{157}$ Rt. 2013 s. 1665 (premiss 40).

${ }^{158}$ Det aktuelle grunnlaget for en eventuell tilbakebetalingsplikt her var lov om offentlig støtte $\S 5$ første ledd.

${ }^{159}$ Rt. 2012 s. 1444 (premiss 34-35).
} 
loven. Denne må etter dommen anses for uttømmende å regulere tilbakesøkning på trygderettens område. Tilsvarende må lov om offentlig støtte $\S 5$ anses å uttømmende regulere spørsmål om tilbakesøkning på sitt område. Også Rt. 2010 s. 1500 gir en pekepinn i retning av at spesiallovgivningens regler utelukker eventuelle krav bygget på ulovfestet rett. Men formuleringene her er mer nyanserte. Det man viser til i dommen, er simpelthen at den søksmålsfristen som er angitt i skattebetalingsloven, ikke kan settes til side der man materielt sett falt innenfor den type tilbakesøkningskrav som skattebetalingsloven regulerte. ${ }^{160}$

Hva slags type tilbakesøkningskrav for feilbetaling som kan tenkes å falle utenfor de tilfeller som skattebetalingsloven regulerer, fremgår imidlertid ikke av dommen. I Rt. 2006 s. 1281, som det henvises til i Rt. 2010 s. 1500 , var det spørsmål om et krav bygget på erstatning kunne reises uavhengig av fristbestemmelsene i daværende skattebetalingslov (1952) § 48 .

Slik jeg leser overnevnte avgjørelser, medfører de lite mer enn en bekreftelse av lex specialisprinsippet på tilbakesøkningens område. Der et krav materielt sett faller innenfor spesiallovgivningen, må ulovfestede regler om tilbakesøkning vike for lovfestede regler ved kollisjon. Krav som kan bygges på grunnlag som materielt sett faller utenfor spesiallovgivningen, kan derimot fremmes i medhold av ulovfestet rett. Hvorvidt ulovfestede regler kan supplere lovfestede regler, må bero på en tolkning av spesialreguleringen. På trygderettens område fremgår det klart av Rt. 2013 s. 1665 at folketrygdlovens bestemmelser er uttømmende. På andre områder, så som på finansavtalelovens område, er det derimot ikke tvilsomt at lovens reguleres suppleres av ulovfestet rett. Her viser finansavtaleloven $\S 31$ eksplisitt til «alminnelige regler».

\subsubsection{Krav mellom andre enn betaler og mottager}

Det ligger i ordet tilbakesøkning at det i utgangspunktet er «den samme» betalingen som skal tilbakeføres. Partene i en tilbakesøkningstvist blir i utgangspunktet derfor den som betalte, mot den som mottok. Men der en av partene hadde et krav eller en forpliktelse, oppstår spørsmål om man kan fremme kravet direkte overfor den som feilaktig har blitt beriket.

For tilfeller av feil betaler er spørsmålet om betaleren kan rette krav mot rette debitor, som har oppnådd en besparelse ved at betaleren har betalt hans gjeld. For disse tilfelle gir Rt. 1979 s. 69 et eksempel på direktekrav fra den feilaktige betaler mot rette debitor. Høyesterett drøfter ikke spørsmålet og uttaler seg heller ikke eksplisitt med hensyn til hvilket grunnlag de bygger på. Likefullt er resultatet av dommen at betalers krav mot rette debitor, og ikke mot mottager, fører frem. Betaleren hadde ikke gjort noen betaling til rette debitor, men hadde ved sin feilaktige betaling til mottager beriket rette debitor ved å innfri dennes forpliktelse. Løsningen er

\footnotetext{
${ }^{160}$ Rt. 2010 s. 1500 (premiss 64), med henvisning til Rt. 2006 s. 1281 (særlig premiss 53-54).
} 
prosesseffektiv ved at man i stedet for at betaler først skal fremme krav om tilbakesøkning overfor mottager, som deretter må fremme et nytt krav mot rette debitor, hopper over mellomleddet og lar kravet rettes direkte mot den som er blitt sittende igjen med den uberettigede berikelsen, i dette tilfellet i form av besparelse.

Det Rt. 1979 s. 69 åpner for, er en adgang til å rette kravet direkte mot rette debitor. Det kan imidlertid ikke være noe vilkår om at betaleren først retter kravet mot denne; i langt de fleste dommene om innfrielse av andres gjeld har kravet vært retter mot mottager. En motsatt regel ville gi betaleren risikoen for at rette debitor er insolvent. At det kun er en adgang, men ikke en plikt, tilsvarer de franske reglene om «action directe» i denne sammenhengen. ${ }^{161}$

Selv om jeg her bruker begrepet «berikelse», er man ikke avhengig av et alminnelig rettslig grunnlag om tilbakeføring av uberettiget berikelse. Kravet bør heller anses som et direktekrav ved feilbetaling. ${ }^{162}$ Hvis kravet anses som et direktekrav, er spørsmålet hvilke begrensninger som må legges på det kravet som kan rettes direkte mot rette debitor. Fra direktekrav mot tidligere leverandørledd for oppfyllingssvikt, kjenner man to modeller for direktekrav: springende regress og subrogasjon. ${ }^{163}$ Oversatt til feilbetalingstilfellene innebærer en springende regress-modell at betalerens direktekrav vil være begrenset både av hans eget tilbakes $\emptyset$ kningskrav overfor mottager $o g$ av mottagers opprinnelige krav mot rette debitor. I en subrogasjonsmodell vil betaleren derimot tre inn i mottagers opprinnelige krav mot rette debitor, uten at dette begrenses av hans eget tilbakes $\varnothing$ kningskrav overfor mottageren.

I Rt. 1979 s. 69 var beløpet betaleren hadde betalt, identisk med beløpet som rette debitor skyldte, slik at det var uten betydning hvilken modell man bygget på. ${ }^{164}$ Har betaleren betalt mer enn rette debitor skyldte, bør kravet mot rette debitor være begrenset til mottagers opprinnelige krav. I motsatt fall vil rette debitors forpliktelse $\varnothing \mathrm{ke}$ som følge av betalerens feilbetaling. Dette resultatet vil man komme til uavhengig av om man bygger på springende regress eller subrogasjon, da betalerens krav mot rette debitor alltid vil være begrenset av mottagers opprinnelige krav. Dersom betaleren har betalt mottager mindre enn rette debitor skyldte, bør direktekravet også være begrenset til betalerens tilbakesøkningskrav mot mottager, altså en springende regress-modell. I motsatt fall vil betaleren oppnå en tilfeldig fordel ved at han får mer tilbake fra rette debitor enn hva han selv betalte til mottager. Dersom rette debitor hadde

\footnotetext{
${ }^{161}$ Code civil artikkel 1302-2 annet ledd.

${ }^{162}$ Dette er også den regelen som følger av fransk rett etter revisjonen av Code civil i 2016, jf. Code civil artikkel 1302-2. Tidligere hadde man i fransk rett bygget denne slags krav på regler om uberettiget berikelse av rette debitor, se Terré (2005) side 1015-1016.

${ }^{163}$ Se generelt om de to modellene hos Lilleholt (2017) side $376 \mathrm{flg}$.

${ }^{164}$ I dommen var tilbakebetalingskravet på 3 kr mindre enn det rette debitor opprinnelig skyldte, men jeg går ut fra at dette beror på en skrivefeil ved angivelsen av beløpet enten i stevningen eller i dommen.
} 
fordringer på mottager til motregning som han nå ikke får nyttet, er det spørsmål om disse skal gå til motregning i kreditors opprinnelige krav. I motsatt fall kan rette debitor risikere ikke å få benyttet disse fordringene, for eksempel hvis kreditor blir insolvent eller fordringene er foreldet. Utgangspunktet bør derfor være at rette debitor har sine opprinnelige innsigelser og sin motregningsadgang mot kreditors opprinnelige krav i behold også der betaleren retter kravet direkte mot ham.

Den andre situasjonen hvor det kan være aktuelt å fremme et «direktekrav», er der betaleren har betalt til feil mottager. Spørsmålet her er om rette kreditor kan fremme kravet mot mottager som har oppnådd en berikelse ved at betaleren har betalt ham noe han ikke hadde krav på. Da spørsmålet ikke har vært oppe for Høyesterett, må det anses uavklart. I disse tilfellene står man overfor en kreditor som krever tilbakesøkning uten overhodet å ha betalt, mot noen som overhodet ikke hadde noen forpliktelse forut for feilbetalingen. Dette i motsetning til tilfellene med feil betaler som er omtalt ovenfor, hvor den som krever tilbakesøkning har ytet, og den kravet rettes mot uansett hadde en opprinnelig forpliktelse overfor kreditor. Ved direktekrav ved feil betaler er det altså tilbakesøkningskravet som fremmes direkte mot rette debitor, mens det ved feil mottager er det opprinnelige kravet kreditor hadde som fremmes direkte mot mottager. Dette kan tilsi at tilfellene med betaling til feil mottager er mer avledet fra utgangspunktet for ulovfestet tilbakesøkning enn tilfellene av feil betaler, slik at en direktekravsadgang ikke bør stå åpen.

I fransk teori har man forfektet en slik adgang, men den har vært avvist i rettspraksis. ${ }^{165}$ Ved endringen av sivillovboken ble det ikke innført en slik direktekravsadgang for den som har betalt til feil mottager. I disse tilfellene må man i fransk rett bygge på reglene om uberettiget berikelse, jf. Code civil artikkel 1303.

\subsection{Oppsummering}

I kapittel 4 har jeg unders $\varnothing \mathrm{kt}$ hvilke forutsetninger, eller grunnvilkår, som må være oppfylt for at domstolene i det hele tatt skal ta konkret stilling til om et krav om tilbakesøkning skal føre frem eller ikke. De eneste absolutte vilkår som kan påvises etter en analyse av rettspraksis, er at det må være skjedd en formuesoverføring, og at denne må savne rettsgrunn. Rettsgrunn foreligger der det forelå foregående forpliktelse, eller der betalingen i seg selv utgjorde en rettslig disposisjon. Sistnevnte må avgjøres konkret på bakgrunn av en vurdering av hvorvidt man kan legge til grunn at betaleren mente å berike mottageren uavhengig av rettslig plikt til å betale.

Analysen har vist at det ikke kan oppstilles noe selvstendig krav om villfarelse. Kravet til feil innebærer ikke noe mer enn at det ikke kan ha foreligget foregående forpliktelse, og at beta-

\footnotetext{
165 Se Bénabent (2017) side 362.
} 
lingen heller ikke må utgjøre en selvstendig rettslig disposisjon. Når dette kan oppstilles som et selvstendig vilkår, får fravær av villfarelse først betydning som et moment ved vurderingen av om betalingen utgjør en selvstendig rettslig disposisjon. Hva slags feil som har foranlediget betalingen, er således ikke et selvstendig grunnvilkår. Det er tilstrekkelig at «feilen» viser seg i at det ikke skulle vært betalt.

Der det finnes spesiallovgivning om tilbakes $\varnothing$ kning, vil ulovfestet tilbakes $\varnothing$ kning ved motstrid måtte vike, i henhold til prinsippet om lex specialis. Hvorvidt det overhodet ikke er plass til ulovfestet rett på områder med lovfestet tilbakesøkningsregler, vil måtte bero på en tolkning av lovbestemmelsen.

For tilfeller av betaling fra feil betaler, hvor man har innfridd annens gjeld, åpner rettspraksis for at tilbakesøkningskravet kan rettes direkte mot rette debitor for den opprinnelige betalingen. Dette kravet bør være begrenset både av betalerens tilbakesøkningskrav og av mottagers opprinnelige krav mot rette debitor. 


\section{$5 \quad$ Tilfeller som kan avgjøres uten helhetsvurdering}

\subsection{Innledning}

I kapittel 4 så vi at dersom det er foretatt en formuesoverføring uten at det forelå en rettsgrunn for den, er grunnvilkårene for å kreve tilbakesøkning etter ulovfestet rett oppfylt. Med henvisning til læren om condictio indebiti har det i praksis vært vist til at man da må foreta en helhetsvurdering av hvorvidt tilbakes $\varnothing$ kning er rimelig. ${ }^{166}$ Til forskjell fra mange andre europeiske land har vi i norsk rett ingen uttalt hovedregel om tilbakesøkning.

Når man ikke har noen uttalt hovedregel, skulle man tro at man ved tilfeller av ulovfestet tilbakesøkning alltid tok en helhetsvurdering, og at denne alltid var helhetlig. Imidlertid viser rettspraksis at Høyesterett i mange saker ikke foretar en bred helhetsvurdering. I seks av sakene som er analysert, er det ikke overhodet foretatt noen helhetsvurdering, for hele eller deler av kravet. ${ }^{167}$ I ytterligere tre saker er det, i det minste for deler av kravet, foretatt en helt kort vurdering. ${ }^{168}$ Selv om Høyesterett hverken foretar en helhetsvurdering eller nevner condictio indebiti i de flere av disse sakene, gjelder alle sakene materielt sett tilbakes $\varnothing$ kning ved feilbetaling og er løst på ulovfestet grunnlag. I alle disse sakene har kravet om tilbakesøkning ført frem. Dette utgjør over halvparten av sakene om tilbakesøkning av feilbetalinger fra de siste 75 årene. ${ }^{169}$

Nedenfor vil jeg undersøke de totalt åtte dommene hvor det er enten ikke er foretatt noen helhetsvurderingen eller hvor helhetsvurderingen har vært svært kort. Denne øvelsen kan være egnet til å identifisere enkelte «typetilfeller», eller «understandarder». ${ }^{170}$ Dersom man kan identifisere enkelte situasjoner hvor det normalt ikke er behov for å foreta en helhetsvurdering for å ta stilling til kravet om tilbakesøkning, vil dette kunne forenkle vurderingen både for parter og rettsanvendere.

\section{$5.2 \quad$ Fellestrekk ved sakene}

\subsubsection{Avgift uten hjemmel}

Blant sakene hvor det overhodet ikke ble foretatt noen helhetsvurdering, gjaldt fem innbetaling av avgift uten tilstrekkelig hjemmel. Tre av sakene gjaldt innbetaling av avgift til det of-

\footnotetext{
166 Se f.eks. Rt. 2008 s. 738 og Rt. 1927 s. 237.

${ }^{167}$ HR-2016-2491-A, Rt. 2012 s. 722 , Rt. 2008 s. 1510 , Rt. 1997 s. 1210 , Rt. 1988 s. 556 og Rt. 1959 s. 1129.

${ }^{168}$ Rt. 1997 s. 1210 , Rt. 1995 s. 1641 og Rt. 1953 s. 1460.

${ }^{169}$ I de resterende syv sakene er det foretatt en helhetsvurdering, se Rt. 2010 s. 816, Rt. 2008 s. 738 , Rt. 2001 s. 1580, Rt. 1998 s. 989 , Rt. 1997 s. 1029 , Rt. 1985 s. 290 og Rt. 1979 s. 69.

${ }^{170}$ Knoph (1939) side 31.
} 
fentlige, ${ }^{171}$ mens de to siste gjaldt innbetalinger til interesseorganisasjoner i medhold i lov. ${ }^{172}$ Der hjemmelen ikke står seg, fremstår det som at man uten videre gir medhold i kravet om tilbakebetaling. En viss reservasjon må muligens gjøres med hensyn til hvilket tidsrom tilbakesøkning kan kreves for. I Rt. 1997 s. 1210 foretok Høyesterett en kort vurdering av den delen av kravet som oppstod forut for saksanlegget. Men da man her hadde ytret protest mot betalingen, måtte kravet føre frem i sin helhet.

Også i Rt. 2010 s. 816 og Rt. 2008 s. 738 var det spørsmål om offentlig avgift, men i begge disse sakene ble det foretatt en full vurdering. Her forelå det imidlertid spesielle forhold som tilsa at det måtte foretas en helhetsvurdering: I Rt. 2010 s. 816 var det snakk om midlertidige betalinger. Selv om Høyesterett ikke ville kalle betalingene for a-konto-betalinger, var det snakk om midlertidige utregninger av betalingssummen, hvor det var en forutsetning om at det skulle gjøres en endelig avregning av faktisk betalingsgrunnlag. Høyesterett synes å legge til grunn at det ved denne typen midlertidige betalinger ligger en forutsetning om et endelig oppgjør med etter- eller tilbakebetaling. På den andre siden var den lange tiden som var gått og det høye tilbakebetalingskravet å anse som slike særlige forhold at det var grunn til å foreta en helhetsvurdering. I Rt. 2008 s. 738 var det ikke bestridt at mottager i utgangspunktet hadde krav på tilbakebetaling. Et slikt krav fulgte av EU-retten. Spørsmålet for Høyesterett knyttet seg til utmålingen av tilbakesøkningsbeløpet, nærmere bestemt om man kunne kreve fradrag for den andelen av avgiftsbyrden som var veltet over på kundene. I saken utgjorde dermed ikke «condictio indebiti» grunnlaget for tilbakesøkningskravet, men helhetsvurderingen ble brukt, tilsynelatende analogisk, som en utmålingsregel. ${ }^{173}$ Den helhetsvurderingen som ble foretatt, var dermed knyttet til, slik Høyesterett så det, fordelingen av en berikelse. ${ }^{174}$ Dette er klart et særlig forhold som skiller saken fra de øvrige sakene om betaling til det offentlige. De to ovennevnte dommene taler derfor ikke imot en hovedregel om at man ved innkreving av avgift uten hjemmel har krav på tilbakebetaling. Tvert imot støtter uttalelser i Rt. 2010 s. 816 klart opp under en slik hovedregel:

«For meg står det som sentralt at det her var tale om ytingar som kraftselskapa var pliktige til å stå for etter lova. Slik eg ser det, må det i alle fall vere eit utgangspunkt at det offentlege som mottakar av avgifter er pliktig til tilbakebetaling der avgift er motteke med urette, så langt tilbakebetalingskravet ikkje er forelda.» ${ }^{175}$

\footnotetext{
171 Rt. 2012 s. 722 , Rt. 2008 s. 1510 , Rt. 1953 s. 1460.

172 Rt. 1997 s. 1210 og Rt. 1959 s. 1129.

${ }^{173}$ Rt. 2008 s. 738 (premiss 41-42).

${ }^{174}$ Ibid. (premiss 49). Denne vurderingen er kommentert under punkt 6.2.6.

${ }^{175}$ Rt. 2010 s. 816 (premiss 61).
} 
Der man står overfor offentlige avgifter, vil man ha lite valg annet enn å betale. Denne tvangssituasjonen alene tilsier at dersom det viser seg at avgiften manglet hjemmel, så må den kunne kreves tilbake. Uttalelsen trekker med styrke i retning av at bare det at avgiften manglet hjemmel, er tilstrekkelig for at krav om tilbakebetaling skal føre frem.

Med hensyn til forbehold må det følge av ovennevnte dom at heller ikke dette er en forutsetning for en hovedregel om tilbakesøkning ved avgift uten hjemmel. I dommen var det ikke tatt forbehold, og Høyesterett la ikke vekt på dette forholdet. Tilsvarende ble det i Rt. $1997 \mathrm{~s}$. 1210 gitt tilbakesøkning også for den av partene som ikke hadde tatt forbehold. Uten at det kan trekkes den slutning at forbehold aldri vil være av betydning, må man kunne konkludere med at en hovedregel om tilbakesøkning vil stå seg selv der det ikke er tatt forbehold.

Den praksis som er gjennomgått ovenfor, er fra de siste 75 år og viser et skifte i tilnærmingen til tilbakes $ø$ kning av offentlige avgifter sammenlignet med tidligere rett. I rettspraksis fra før 1930-tallet var det nærmest et vilkår om forbehold for å kunne kreve tilbakesøkning av uriktig betalt skatt. ${ }^{176}$ Dette ble myket opp i Rt. 1933 s. 323, hvor Høyesterett, etter en helhetsvurdering, kom til at tilbakesøkning kunne innrømmes. ${ }^{177}$ I dag er tilbakeføring av skatt regulert i loven. ${ }^{178}$

\subsubsection{Mottager i positiv ond tro}

I tre av sakene hvor Høyesterett ikke har foretatt en full vurdering, var mottageren i positiv ond tro. ${ }^{179}$ I dette legger jeg at mottageren ikke bare hadde vært uaktsom, men at han satt med kunnskap som gjorde at han visste at han ikke hadde krav på betalingen. I alle disse sakene kom Høyesterett fort til at betaleren hadde krav på å få pengene tilbake. Det var ikke behov for noen helhetsvurdering, da forbehold, tiden som var gått, eller andre forhold ikke kunne få noen betydning: Det sentrale er at rettsordenen ikke vil beskytte den som har tilegnet seg midler han ikke har krav på, vitende om at han ikke har krav på dem. ${ }^{180}$

Av uttalelsene fra HR-2016-2491-A følger det klart at der avtaleloven § 31 kommer til analogisk anvendelse, må hovedregelen være tilbakes $\varnothing \mathrm{kning} .{ }^{181} \mathrm{Ut}$ fra Høyesteretts henvisning til Hagstrøms omtaler av ugyldighetsreglene i avtaleloven $\S \S 30$ og 33 må det kunne legges til grunn at dette utgangspunktet også må gjelde ved svik og uredelighet. Det finnes ingen dommer som motsier en hovedregel om tilbakesøkning der mottageren vet at han ikke har rett på

\footnotetext{
${ }^{176}$ Rt. 1927 s. 237.

177 Rt. 1933 s. 323.

${ }^{178}$ Skattebetalingsloven $\S 7-3$.

${ }^{179}$ Se HR-2016-2491-A, Rt. 1995 s. 1641 og Rt. 1988 s. 556.

${ }^{180}$ Den korte helhetsvurdering som gjøres i Rt. 1995 s. 1641, gjaldt kravet mot skipets panthavere, som hadde vært i god tro. For skipets eiere, som var i ond tro, ble det ikke gjort noen vurdering overhodet.

${ }^{181}$ HR-2016-2491-A (premiss 83).
} 
de mottatte midlene. ${ }^{182}$ Etter dette må man kunne konstatere at der betalingen er fremprovosert av en mottager i positiv ond tro, må betalingen uten videre tilbakeføres. Hvorvidt samme løsning må gjelde der mottageren ikke aktivt har fremprovosert betalingen, men like fullt var i positiv ond tro ved mottagelsen, er ikke eksplisitt løst ved rettspraksis. Her gir imidlertid straffedommene vist til under punkt 4.3.3 klar støtte til en hovedregel om at også ved passiv mottagelse i positiv ond tro må betalingen kunne kreves tilbake uten at man behøver foreta en helhetsvurdering. ${ }^{183}$

\subsection{Saker hvor det må foretas helhetsvurdering}

De sakene hvor det har blitt foretatt en helhetsvurdering, kan ved første øyekast fremstå mindre ensartet, men de har likevel noen fellestrekk som er verd å merke seg. I de fleste av dommene står man overfor godtroende mottager som har hatt en forventning om betaling eller grunn til å regne med at betalingen skal være endelig. Det er altså først og fremst i de tilfellene hvor hensynet til mottager gjør at tilbakesøkning kan være betenkelig, at man foretar en helhetsvurdering.

I fire av sakene stod man overfor tilfeller av feil betaler. ${ }^{184}$ Dermed hadde mottager et krav på pengene fra andre, og han hadde en berettiget forventning om betalingen. Forutsatt at han ikke hadde grunn til å betvile at betaleren var rette kreditor, var det ingen grunn til at han skulle betvile at dette var penger han hadde rett på. I én av sakene var det snakk om utilstrekkelig rettsgrunn. ${ }^{185}$ Her forelå et mellomværende mellom partene, og de midlertidige utregningene, den lange tiden og det store beløpet, utgjorde særlige grunner som er egnet til å forklare at man likevel foretok en helhetsvurdering. I en annen sak var det i og for seg ikke omtvistet at mottager hadde krav på tilbakesøkning. ${ }^{186}$ Helhetsvurderingen i denne saken var altså ikke knyttet til om tilbakebetalingskravet som sådan skulle føre frem, men til spørsmål om det skulle gjøres fradrag i tilbakebetalingsbeløpet. Den siste saken gjaldt komplett fravær av rettsgrunn, men hvor mottager var godtroende tredjepart. ${ }^{187}$ Selv om de faktiske forhold viste seg å være slik at mottager ikke hadde noe krav overhodet, var mottager ved mottagelsen av pengene $\mathrm{i}$ en villfarelse om at han hadde krav på pengene.

\footnotetext{
${ }^{182}$ I både Rt. 2001 s. 1580 og Rt. 1985 s. 290 var mottageren i god tro, selv om betalingen var foranlediget av svikaktige handlinger fra tredjemann.

${ }^{183}$ Se Rt. 2008 s. 1582 og Rt. 2003 s. 1243.

${ }^{184}$ Rt. 2001 s. 1580 , Rt. 1998 s. 989, Rt. 1997 s. 1029 og Rt. 1979 s. 69.

${ }^{185}$ Rt. 2010 s. 816.

${ }^{186}$ Rt. 2008 s. 738.

${ }^{187}$ Rt. 1985 s. 290.
} 


\section{$5.4 \quad$ Oppsummering}

Det vi har sett i kapittel 5, er at man basert på rettspraksis kan oppstille noen utgangspunkter for når man behøver foreta en konkret helhetsvurdering, og når man kan konkludere på bakgrunn av at grunnvilkårene er oppfylt. Der det gjelder krav om tilbakesøkning av innbetalte avgifter som savner tilstrekkelig lovhjemmel, er hovedregelen tilbakes $\varnothing$ kning. Dette innebærer imidlertid ikke at man i disse tilfellene aldri skal måtte foreta en konkret helhetsvurdering. Der det foreligger særlige momenter, kan det være grunn til å vurdere om tilbakes $\emptyset$ kning er rimelig etter en helhetsvurdering.

Der mottageren har vært klar over at han ikke hadde krav på pengene, altså i positiv ond tro, er det også en hovedregel om tilbakesøkning. I disse tilfellene vil det nok være vanskelig å begrunne unntak fra hovedregelen. I alle fall for tilfeller hvor mottager i positiv ond tro aktivt har fremprovosert betalingen, må uttalelsene i HR-2016-2491-A innebære en nær absolutt regel om tilbakebetaling, slik at helhetsvurderingen er overflødig.

De sakene hvor det må foretas en helhetsvurdering, kan ikke fullt ut defineres positivt. Men det vi har sett ovenfor, er at fellestrekket for de fleste sakene er at mottageren i liten grad kan bebreides for å ha trodd å ha rett på pengene, slik at man har funnet grunn til å vurdere konkret i den enkelte sak om tilbakesøkning bør føre frem. 


\section{Innholdet i helhetsvurderingen}

\subsection{Innledning}

I kapittel 4 viste jeg at to grunnvilkår må være på plass for at tilbakesøkning overhodet skal komme på tale. I kapittel 5 så vi at der grunnvilkårene var på plass, var det ikke bestandig nødvendig å foreta en helhetsvurdering. Der mottager har vært i positiv ond tro, er hovedregelen tilbakesøkning. Her er det vanskelig å se for seg forhold som kan medføre et annet resultat. Det andre tilfellet, hvor det er krevet avgift uten hjemmel, er også hovedregelen at tilbakesøkning skal skje. Imidlertid er det her ikke grunnlag for å oppstille en absolutt regel. De momentene som gjøres rede for nedenfor, vil dermed også etter omstendighetene kunne trekkes inn som argumenter for at man også ved her må foreta en helhetsvurdering.

Nedenfor ser jeg på hvilke momenter Høyesterett har trukket frem i praksis. Disse vil ha alminnelig relevans for spørsmålet om tilbakes $\varnothing$ kning. Jeg vil også undersøke om man på bakgrunn av dommene kan trekke generelle slutninger eller utlede vektingsnormer for de forskjellige momentene.

\subsection{Relevante momenter ved helhetsvurderingen}

\subsubsection{Forbehold og protest}

Et moment som hyppig nevnes i rettspraksis, er at betaleren har, eller ikke har, tatt forbehold om tilbakesøkning. Der betaleren har gitt uttrykk for å bestride betalingsplikten uten å ta et konkret forbehold, snakker man gjerne om betaling under protest.

Der det er tatt forbehold, trekkes dette gjerne frem av Høyesterett i favør av at tilbakesøkning skal innrømmes. Eksempler på dette er Rt. 2012 s. 722, Rt. 1997 s. 1210 og Rt. 1995 s. 1641. I Rt. 1979 s. 69 ble det for kravet mot selger lagt vekt på at man hadde protestert, selv om det ikke var snakk om et klart forbehold.

Der forbehold ikke er tatt, er slutningen usikker. I en rekke eldre dommer er tilbakesøkning nektet på grunnlag av at forbehold ikke var tatt. ${ }^{188}$ Til støtte for at et slikt syn fortsatt er uttrykk for gjeldende rett, kan man trekke frem uttalelser fra Rt. 1997 s. 1210. I dommen uttaler Høyesterett først at det for spørsmålet om tilbakesøkning av beløpene som var innbetalt før saksanlegget, var «avgjørende» at det ble gitt «uttrykkelige reservasjonserklæringer i tilknytningen til avgiftsbetalingen». ${ }^{189}$ Når Høyesterett bruker uttrykket «avgjørende» ville det være

\footnotetext{
188 Se f.eks. Rt. 1930 s. 764, Rt. 1927 s. 1052 og Rt. 1927 s. 237.

${ }^{189}$ Rt. 1997 s. 1210 (side 1216).
} 
nærliggende å tro at fraværet av forbehold ville ført til motsatt resultat. Imidlertid var nettopp dette tilfellet for en av betalerne, men Høyesterett gav like fullt medhold i tilbakes $\emptyset$ kningskravet også for den av partene som ikke hadde tatt forbehold, uten at dette var begrunnet i annet enn at man fant det «lite naturlig å skille mellom ham og de $\varnothing$ vrige saks $\varnothing k e r e . »{ }^{190}$ Til støtte for at fravær av forbehold ikke bør tillegges vekt, kan det vises til Rt. 2010 s. 816, Rt. 1988 s. 556 og Rt. 1933 s. 323, som alle gir klart uttrykk for at fravær av forbehold ikke nødvendigvis kan tale mot tilbakes $\varnothing \mathrm{kning}$.

Fra rettspraksis kan man slutte at der forbehold er tatt, taler dette i favør av tilbakesøkning. Hvilken relativ vekt i møte med andre momenter dette skal ha, sier derimot rettspraksis lite om. Hva man derimot kan slutte fra fravar av forbehold er uklart. Her må det i større grad bero på situasjonen om det var grunn til å forvente at forbehold ble tatt, eller om fravær av forbehold har ført til innrettelse hos mottageren på at betalingen er endelig. Noe generelt om slutning og vekt av fravær av forbehold kan derfor ikke sies.

Også i Rt. 2012 s. 722, som gjaldt betaling av foreldet gjeld, var betalerens forbehold av betydning. Men slik jeg leser dommen, var dette et avgjørende forhold for vurderingen av hvorvidt man overhodet hadde tilbakes $\emptyset \mathrm{k}-$ ningskravet i behold, og ikke et moment ved noen helhetsvurdering. Derfor var det i saken grunn til å legge avgjørende vekt på forbeholdet. Dersom det i denne saken ikke var tatt et forbehold, ville det vært nærliggende å legge til grunn at tilbakesøkning var utelukket fordi betalingen gikk til oppfyllelse av en «ikke-rettslig» forpliktelse, se punkt 4.3.5.4.

\subsubsection{Partenes subjektive forhold}

\subsubsection{Betalerens aktsomhet}

Partenes subjektive forhold trekkes ofte inn i helhetsvurderingen. Det vises gjerne til om betaleren har utvist tilstrekkelig aktsomhet, og om mottager er i aktsom god tro. Selv om formuleringene varierer, er alle disse forholdene knyttet til hvem som var mest å bebreide eller nærmest til å avverge feilbetalingen.

I flere dommer er det vist til at betaleren ikke særlig kan bebreides: I Rt. 2001 s. 1580, hvor borettslaget, som flertallet anså som betaler, ikke var klar over at det var overført penger i det hele tatt, uttalte førstvoterende at det «ikkje kan seiast at burettslaget handla aktlaust ved å gi rekneskapsføraren fullmakt». ${ }^{191}$ Også i Rt. 1995 s. 1641 , Rt. 1985 s. 290 og Rt. 1934 s. 400 er det konstatert at man ikke fant grunn til å bebreide betaleren for å ha utbetalt.

\footnotetext{
190 Ibid.

${ }^{191}$ Rt. 2001 s. 1580 (side 1586).
} 
Rt. 1998 s. 989 gir et eksempel på at Høyesterett mente at betaleren i noen grad var å bebreide. Det ble uttalt at betalerens rutiner «neppe [kunne] anses som betryggende.» ${ }^{192}$ Mottagerne hadde i saken anført uaktsomhet fra betaleren, men selv om Høyesterett fant grunn til å kritisere rutinene, kunne dette ikke få «avgjørende betydning for sakens utfall.»193

Et annet eksempel på at Høyesterett har funnet betaleren noe å bebreide, er Rt. 1997 s. 1029. I dommen trakk Høyesterett frem at det var nærliggende å la betaleren «ha risikoen for at selskapet var uforpliktet til å dekke skaden». ${ }^{194}$ I dommen hadde Høyesterett først konkludert med at mottageren var i aktsom god tro ved mottagelsen av beløpet. Uten at det uttales eksplisitt, må den risikovurderingen Høyesterett foretok, anses å bygge på at man i noen grad kunne bebreide betaleren for ikke å ha oppdaget at han var uforpliktet. Som det sies i dommen, var opplysningene om når skaden inntraff, som var av betydning for betalerens forpliktelse, tilgjengelig for betaleren. ${ }^{195}$

Der betaleren har vært uaktsom, trekker dette i retning av å nekte tilbakes $\emptyset$ kning. Imidlertid er både terskelen for og vekten av en eventuell uaktsomhet usikker. Rt. 1997 s. 1029 kan trekke i retning av at uaktsomhet tillegges betydelig vekt. Samtidig er det fra denne dommen vanskelig å trekke klare slutninger, da det er uklart om uaktsomheten i seg selv var avgjørende, eller om den kun fikk betydelig vekt i fravær av andre momenter.

\subsubsection{Mottagers aktsomhet}

Mottagers gode eller onde tro trekkes frem i flere dommer. Der mottager vet at han ikke har rett på det som er mottatt, er hovedregelen at tilbakesøkning skal skje, se punkt 5.2.2. Her er det vanskelig å se grunner til at tilbakesøkning skal nektes. Vanskeligere er det med tilfellene der mottager har vært mer eller mindre uaktsom. For disse tilfellene kan man ikke oppstille en tilsvarende klar regel. Samtidig er det klart at uaktsomhet hos mottageren er et moment av relevans. I Rt. 1979 s. 69 trekker Høyesterett frem at «mottageren» burde ha vært klar over at betaleren ikke hadde plikt til å betale, og var klar over at betaleren var bragt i en vanskelig situasjon grunnet uklarheter som «mottager» var skyld i. ${ }^{196}$

Selv om mottager er i god tro, får ikke dette nødvendigvis betydning for helhetsvurderingen. I Rt. 2010 s. 816 ble det påpekt at i den grad mottager var i god tro, kunne det ikke tillegges

\footnotetext{
192 Rt. 1998 s. 989 (side 1000).

193 Ibid.

194 Rt. 1997 s. 1029 (side 1035).

195 Ibid. (side 1035-1036).

196 «Mottager» er her selger, som ble skyldig å betale tilbake til betaleren. Men selger var i saken ikke mottager av feilbetalingen, se punkt 4.6.2.
} 
vekt i saken. Uavhengig av god tro ved innkrevingen måtte kommunen være «klar over at det var tale om kompliserte fastsetjingar, som ikkje var endelege før også kraftgrunnlaget var fastsett». ${ }^{197}$ I nevnte dom var det et poeng at man sto ovenfor innkreving av avgifter til en offentlig mottager. At mottagers gode tro har begrenset vekt i møte med det offentlige, følger også av Rt. 2008 s. 738. ${ }^{198}$

I Rt. 2001 s. 1580 ble det først konstatert at mottageren selv var i god tro. Men da denne gode troen hvilte på regnskapsførerens beretninger, kunne det likevel ikke være tilstrekkelig for å anse mottageren i god tro. Regnskapsføreren hadde vært i positiv ond tro og var skyldig i underslag. Mottageren ble altså identifisert med regnskapsføreren med hensyn til godtrovurderingen.

Der mottager har vært uaktsom, taler dette for tilbakesøkning. Hvilken relativ vekt det skal ha, er likevel usikkert. I Rt. 1979 s. 69 fremstår det som at det er snakk om et moment av betydning, men her må nok også graden av bebreidelse som kan rettes mot betaleren, spille inn på vekten. Med andre ord fremstår vekten av mottagers uaktsomhet som relativ til vekten av betalers uaktsomhet.

Fra at uaktsomhet taler i mottagers disfavør, kan man ikke slutte noen antitese. I de fleste dommene stod man overfor godtroende mottagere, hvilket i så fall skulle tilsi at tilbakesøkning ble nektet. Likevel ble resultatet i de aller fleste dommene at tilbakesøkning ble innrømmet, til tross for mottagers gode tro. Et unntak er Rt. 1997 s. 1029, men her var som nevnt også betaleren i noen grad å bebreide for feilbetalingen. Når Høyesterett flere ganger har uttalt at mottagers gode tro, i den konkrete saken, ikke kan tillegges vekt, tilsier dette at man generelt ikke legger stor vekt på mottagers gode tro som et argument for nektelse, utover å se det som et slags minstekrav.

\subsubsection{Tredjemanns forhold}

Der det er tredjemann som i ond tro har fremprovosert betalingen, vil også tilbakesøkningskravet stå særlig sterkt. Dette gjelder selv om mottageren selv er i god tro. Eksempler på dette har vi i Rt. 1995 s. 1641, Rt. 1985 s. 290 og Rt. 1934 s. 33, som alle gjaldt forsikringsutbetalinger i forbindelse med skipsforlis gjort til skipets panthavere, hvor det viste seg at hovedsikrede selv hadde senket skipet. I Rt. 2001 s. 1580 var det spørsmål om tilbakes $\varnothing$ kning av betalinger utført av en utro tjener, som hadde underslått midler i et borettslag hvor han var forretningsfører.

\footnotetext{
${ }^{197}$ Rt. 2010 s. 816 (premiss 64).

${ }^{198}$ Rt. 2008 s. 738 (premiss 48).
} 
For situasjoner hvor betalingen er fremprovosert av tredjemann ved kriminelle handlinger, kan man trekke en sikker slutning fra rettspraksis om at dette taler for tilbakesøkning, og man kan også legge til grunn at dette har betydelig vekt. Dette følger eksplisitt av Rt. 2001 s. 1580, hvor det ble uttalt at «det i sterk grad talar for gjenoppretting at betalinga har skjedd ved ei kriminell handling». ${ }^{199}$ Samtidig tilsier uttalelsen at det ikke er snakk om en absolutt regel. Det kan altså tenkes at tilbakesøkning likevel må nektes. I Rt. 2001 s. 1580 ble mottager identifisert med tredjemann som var i positiv ond tro. Dermed skulle det nok svært mye til for at man skulle nekte kravet. Men også i de andre dommene med tredjemann i positiv ond tro har kravet ført frem selv om det ikke ble foretatt en slik identifikasjon, jf. Rt. 1995 s. 1641 og Rt. 1985 s. 290. I alle sakene var mottager personlig i god tro. At betaleren i Rt. 2001 s. 1580 hadde gitt regnskapsføreren de fullmakter som muliggjorde underslaget og dermed feilbetalingen, kunne ikke medføre at betaleren var å bebreide. Heller ikke at i Rt. 1985 s. 290 fant man grunn til å bebreide forsikringsselskapet for utbetalingen, uavhengig av om direktøren i selskapet hadde hatt mistanker om at tredjemann i saken hadde påført skaden selv. I alle sakene var det dessuten gått relativt lang tid, uten at dette kunne medføre at tilbakesøkning måtte nektes.

Rettspraksis ovenfor gir inntrykk av at terskelen for når tilbakes $\emptyset$ kning kan nektes der feilbetalingen skyldes tredjemanns kriminelle forhold, er høy. At mottager selv er i aktsom god tro, er ikke tilstrekkelig. Det kan også virke som at terskelen for å rette bebreidelser mot betaleren er høy. Det er i alle fall ikke tilstrekkelig at forhold hos betaleren muliggjorde den kriminelle handlingen, jf. Rt. 2001 s. 1580. Den som vil argumentere mot tilbakesøkning, bør nok bygge argumentasjonen på at betalingen $i$ like stor grad var følge av betalers uaktsomhet som av tredjemanns forhold, slik at tredjemanns forhold ikke var av avgjørende betydning for feilbetalingen, og at betalerens uaktsomhet ved å muliggjøre tredjemanns svik var mer fremtredende enn mottagers uaktsomhet ved ikke å ha avdekket det.

\subsubsection{Betalingssituasjonen}

I rettspraksis er selve betalingssituasjonen ved flere anledninger trukket frem som et moment. I Rt. 1988 s. 556 og Rt. 1985 s. 290 var det trukket frem at betaleren var i en tvangssituasjon, og at dette talte for tilbakesøkning. At man står overfor pliktige ytelser, er også trukket frem som et argument for tilbakesøkning i flere dommer, jf. Rt. 2010 s. 816 og Rt. 1997 s. 1210. Resonnementet her blir det samme som ved tvangssituasjonen, nemlig at dette først og fremst er et argument mot å se betalingen som en rettslig disposisjon, og for at betaleren ikke kan bebreides for å ha ytet.

\footnotetext{
${ }^{199}$ Rt. 2001 s. 1580 (side 1586).
} 
Der betaleren var i en tvangssituasjon, kan man fra rettspraksis utlede en rimelig klar regel om at tilbakesøkning skal innrømmes. Dette gjelder tilsvarende for pliktige ytelser. Derimot kan man ikke uten videre trekke antiteser fra dette argumentet: Fraværet av en tvangssituasjon betyr ikke at tilbakesøkning må nektes, og vil neppe tillegges særlig selvstendig vekt. ${ }^{200}$

At man stod ovenfor en midlertidig betaling, trekkes særlig frem i Rt. 2010 s. 816. Hvilken betydning dette hadde for resultatet er dog uklart. Allerede før flertallet gikk over på helhetsvurderingen, konstaterte de at offentlige avgifter som er mottatt med urette, som utgangspunkt måtte kunne kreves tilbake. Deretter gikk de gjennom de innsigelsene som var fremmet mot tilbakesøkning, og avviser dem én etter én. Det eneste stedet det forhold at det var tale om midlertidige betalinger synes å ha blitt tillagt vekt, var ved spørsmålet om hvilken periode det kunne kreves tilbakebetaling for. Det var her snakk om en 20-årsperiode. Høyesterett konstaterte at ordningen med midlertidige betalinger «snarare [taler] for ei plikt til etteroppgjer enn mot dette». Selv om Høyesterett her ikke eksplisitt omtalte betalingen som en a-kontobetaling, fremstår det bærende hensynet å være at mottager ved midlertidige betalinger hvor det forutsettes at det skal foretas en etterberegning, ikke kan ha særlige forventninger om at oppgjøret er endelig. At dette momentet har generell relevans for hvorvidt tilbakesøkning skal innrømmes, er derfor tvilsomt; det bør først og fremst anses som et argument for at man ikke bestandig skal legge vekt på at det er gått lang tid fra feilbetaling til krav om tilbakebetaling.

Beløpets størrelse er i flere saker nevnt, uten at det fremgår klart hva som kan utledes fra dette momentet. I Rt. 2010 s. 816 uttalte Høyesterett at det var tale om et beløp av en viss størrelse, men at dette ikke kunne tale mot tilbakesøkning; det lå i avgiftens natur at det kunne beløpe seg store summer. I motsatt ende nevnes det i Rt. 1997 s. 1210 at det kun var tale om mindre beløp for den enkelte betaler, og at dette kunne tale imot tilbakesøkning. Resultatet i dommen ble imidlertid at kravet om tilbakesøkning førte frem. Fra betalingens størrelse kan man altså ikke trekke noen generell slutning.

\subsubsection{Tidsmomentet}

\subsubsection{Tiden mellom feilbetaling og tilbakesøkningskrav}

Tidsmomentet er i teorien fremhevet som et særlig viktig moment. ${ }^{201}$ Momentet nevnes i de fleste dommer. Når man snakker om tidsmomentet, viser det både hvor lang tid som er gått

\footnotetext{
200 Se f.eks. Rt. 1998 s. 989.

${ }^{201}$ Se f.eks. Bergsåker (2015) side 281 og Hagstrøm (2011) side 708.
} 
siden betalingen, og hvor lang tid som er gått mellom feilen ble oppdaget og kravet ble fremmet.

Tiden mellom feilbetalingen og kravet blir fremsatt, om det har gått lang eller kort tid, er trukket frem som et moment i flere dommer. I Rt. 2010 s. 816 gikk tilbakes $\emptyset$ kningskravet 20 år tilbake i tid, uten at dette kunne tillegges vekt mot tilbakesøkning. I Rt. 2001 s. 1580 hadde det gått 15 måneder fra betalingen til krav om tilbakebetaling ble fremsatt, men dette kunne «ikkje i seg sjølv vere for lang [tid]». ${ }^{202}$ I dommen er det vist til Rt. 1985 s. 290, hvor man heller ikke anså det for å ha gått for lang tid, selv om 19 måneder var gått mellom betaling og tilbakesøkningskravet.

I Rt. 1998 s. 989 uttalte Høyesterett at det for den aktuelle typen betaling, hvor betalingen innebar et risikomoment for banken, måtte det kreves at det ble reagert raskt. I første omgang hadde banken her ensidig korrigert betalingen, hvilket man her kom til at de var berettiget til. Da banken senere omgjorde korrigeringen, og utbetalte beløpet til mottagerne på nytt, ble dette gjort med forbehold om fremtidig tilbakesøkning. Elleve måneder senere ble det krevet tilbakebetaling. For dette kravet var spørsmålet mer tvilsomt, men også her kom man til at kravet var i behold, og man viste blant annet til at det var gitt et, om enn forsiktig, forbehold.

I Rt. 1979 s. 69 var det for kravet mot mottager ikke krevet tilbakesøkning før syv måneder etter betaling. Dette ble ansett for å være for lang tid. Denne relativt korte fristen må imidlertid ses i lys av de spesielle forhold i saken. Betaleren hadde for Høyesterett fremmet krav mot både mottager og rette debitor for betalingen, se punkt 4.6.2. Dermed ble det et spørsmål om plassering av ansvaret. Da man fant at rette debitor i særlig stor grad var å bebreide for feilbetalingen, førte kravet mot ham frem. Betalerens interesser var derfor allerede tilstrekkelig ivaretatt. Siden Høyesterett her kom til at rette debitor var mer å bebreide enn mottager, er det mulig at dette også spilte inn ved vurderingen av om begge eller bare rette debitor skulle holdes ansvarlig for tilbakebetalingsbeløpet. Fra senere høyesterettsrettspraksis har man ingen andre eksempler på at syv måneder er ansett som for lang tid. For kravet mot rette debitor var det i dommen protestert allerede én måned etter betaling, og krav ble fremmet fire måneder etter betaling.

Til tross for at tidsmomentet fremheves både i teori og rettspraksis, har man altså ingen eksempler fra nyere praksis på at Høyesterett eksplisitt har tillagt det avgjørende vekt. Ser man først på den tiden som er gått mellom feilbetalingen og kravet, har man en rekke eksempler på

${ }^{202}$ Rt. 2001 s. 1580 (side 1687). 
at tilbakesøkning har ført frem, selv om det er gått lang tid. ${ }^{203}$ I Rt. 1997 s. 1029, hvor tilbakesøkning ble nektet, var det kun gått om lag ett år. Høyesterett uttalte at dette «i en viss grad støtter [mottager]». ${ }^{204}$ At man hadde en rekke tidligere dommer hvor det var gått betydelig lengre tid, uten at dette stengte for tilbakesøkning, ble ikke kommentert. ${ }^{205}$ At det kan foreligge forhold som tilsier at man ikke kan legge vekt på tiden som er gått, er ikke bestridt i rettspraksis og er naturligvis forklaringen på at tidsmomentet ikke i seg selv kan være avgjørende. Men med dette i mente er det merkelig at momentet trekkes frem nettopp som et tungtveiende moment. Da ville man også anta at det kunne vises til at det hadde større selvstendig betydning.

\subsubsection{Tiden mellom kunnskap om feilen og tilbakesøkningskrav}

Når det gjelder tidsrommet fra kunnskap om feilbetalingen til krav er fremmet, ble dette særlig drøftet i Rt. 2001 s. 1580. Høyesterett anla her synsvinkelen passivitet. Ut fra en slik synsvinkel, er det ingen grunn til at tiden mellom kunnskap og krav skal anses som et selvstendig moment ved helhetsvurderingen. ${ }^{206}$ Den fremgangsmåte Høyesterett anla, tilsier at man først vurderer om det foreligger et krav, for deretter å vurdere om dette er bortfalt ved passivitet. Dette er en tilnærming man kjenner fra obligasjonsretten for øvrig, og den er eget til å klargjøre vurderingstemaet.

\subsubsection{Andre hensyn}

Som omtalt i forrige kapittel, står krav om tilbakes økning fra det offentlige, der det er krevet inn skatt eller avgift uten hjemmel, i en særstilling. Hovedregelen må her være tilbakesøkning, og dersom det skulle foreligge forhold som tilsier at tilbakesøkning skal nektes, må det forventes at det her kreves enda sterkere mothensyn enn ellers.

I både Rt. 2001 s. 1580 og i Rt. 1997 s. 1029 trekkes det frem at man står overfor en betaling det ikke forelå plikt for, og at dette i seg selv talte for tilbakesøkning. Fravær av plikt er en forutsetning for tilbakesøkning, hva jeg betegner som grunnvilkår. At dette også skal være et moment ved en helhetsvurdering, trekker i retning av en presumpsjon om tilbakebetaling, da grunnlaget for kravet blir et argument i seg selv.

\footnotetext{
${ }^{203}$ Rt. 2010 s. 816 , Rt. 2001 s. 1580 , Rt. 1995 s. 1641 og Rt. 1985 s. 290.

${ }^{204}$ Rt. 1997 s. 1029 (side 1036).

205 Rt. 1995 s. 1641 og Rt. 1985 s. 290.

${ }^{206}$ I den grad man legger vekt på mottagers innrettelse på betalingen, vil imidlertid all tid mellom feilbetalingen og tilbakesøkningskravet kunne være relevant for mottagers innrettelse, men tiden blir da ikke et selvstendig moment, se punkt 7.4.2.2.
} 
Hensynet til at betalinger skal bestå, ofte kalt oppgjørshensyn, trekker i motsatt retning av momentet ovenfor. Dette fremstår imidlertid som et hensyn, mer enn et moment, da det ikke er noe som oppstår fra faktum i saken. Tvert imot er det et navn på resultatet, nemlig at det alt $\mathrm{i}$ alt er rimeligst at betalingen blir værende hos den uberettigede mottager. Men hvorfor man skal komme til dette resultatet, sier ikke hensynet noe om, utover hva som kan utledes av momentene i faktum. Hensynet er trukket frem både i Rt. 1979 s. 69, Rt. 1985 s. 290 og Rt. 1998 s. 989, uten at det i noen av sakene har gitt utslag på resultatet.

Et moment som kan synes å ha en viss vekt, er hvorvidt betaleren kan få dekket sitt «tap» andre steder. Et eksempel på dette har man i Rt. 1997 s. 1029 hvor Høyesterett nevner at betaleren normalt vil ha et regresskrav mot rette debitor, slik at dette slår ut i godtroende mottagers favør. Dette momentet ble holdt sammen med at «tvil om hvilken assurandør som rettelig skal erstatte tapet, skal være en konflikt mellom assurandørene». ${ }^{207}$ I alle fall der betaleren i noen grad er å bebreide, vil regressadgangen kunne gjøre det enklere å begrunne at tilbakesøkning nektes. På forsikringsrettens område fremstår det som at uttalelsen også tas til inntekt for en mer generell risikoplassering, hvor disse feilene ikke skal gå utover forsikringstageren som uansett ville hatt et krav mot ett av selskapene. ${ }^{208}$

Et litt annet eksempel på at Høyesterett flyttet oppmerksomheten fra den opprinnelige feilaktige berikelsen av mottager til betalerens tap, har man i Rt. 2008 s. 738. Siden betaler hadde fătt sine utgifter ved den ulovlige avgiften dekket inn ved $\varnothing$ kte priser fra kundene, kom man her til at mottager ikke var pliktig til å tilbakebetale denne delen av beløpet. ${ }^{209}$ Selv om grunnlaget for tilbakesøkning i dommen fulgte av EU-retten ble utmålingen avgjort etter en helhetsvurdering, med henvisning til condictio indebiti. ${ }^{210}$ Det må derfor følge av dommen at der

\footnotetext{
${ }^{207}$ Rt. 1997 s. 1029 (side 1036).

${ }^{208}$ Se henvisninger til Rt. 1997 s. 1029 i HR-2017-2414-A (premiss 47-49).

${ }^{209}$ De lege ferenda kan måten Høyesterett benytter berikelsessynspunkter i Rt. 2008 s. 738, kritiseres. I saken kom Høyesterett til at betaleren, KLM, ville oppnå en «berikelse» ved tilbakesøkning. KLMs «berikelse» bestod i at de hadde fătt sine utgifter til den ulovlige avgiften dekket ved $\varnothing \mathrm{kte}$ priser til sine kunder, slik at tilbakeføring ville medføre en dobbelt inndekning av utgiftene. Høyesterett anså spørsmålet i saken som en fordeling av en berikelse, men det var kun staten som i dette tilfellet var blitt beriket på motpartens bekostning. Staten hadde på bakgrunn av inntekter fra den ulovlige avgiften beriket seg på KLMs bekostning. KLM hadde derimot ikke mottatt noen berikelse fra staten, men simpelthen pulverisert sitt opprinnelige tap ved overvelting på kundene. Heller ikke en plikt for staten til å tilbakebetale ville medført en berikelse av KLM på statens bekostning, all den stund staten under enhver omstendighet ikke hadde hatt krav på inntektene fra avgiften. Overveltingen var dermed uvedkommende for forholdet mellom KLM og staten. Den argumentasjonen Høyesterett her bygger på, innebærer at man i realiteten flytter gjenstanden for tilbakes $\varnothing$ kning fra den opprinnelige betalingen og mottagers berikelse, til et spørsmål om betaleren har lidt et netto tap ved feilbetalingen. På engelsk blir den type argumentasjon som staten her vant frem med, kalt «disimpoverishment» eller «passing on», og er ikke akseptert i engelsk rett som grunnlag for å nekte tilbakes $\varnothing$ kning, se Birks (2005) side 219-221.
}

${ }^{210}$ Rt. 2008 s. 738 (premiss 42) 
betaleren har fått sine utgifter til feilbetalingen dekket, vil dette kunne være et relevant moment mot full tilbakebetaling. I alle fall må dette være tilfellet for avgiftstilfellene. ${ }^{211}$

Ved siden av de momentene som er trukket frem ovenfor, og som alle er nevnt i høyesterettspraksis, har man i teorien gjerne omtalt fordringens art eller karakter som et selvstendig moment. ${ }^{212}$ For de lovregulerte tilfellene er dette klart tilfellet. ${ }^{213}$ Derimot er dette momentet ikke vist til i nyere rettspraksis. Nært beslektet med fordringens art er partenes profesjonalitet. Dette momentet er også trukket frem i teorien, uten at det kan vises til særlig støtte i praksis. ${ }^{214}$ Den dommen Hagstrøm viser til, Rt. 1995 s. 1641, gir lite grunnlag for å trekke en bastant slutning om momentets relevans: I saken stod tvisten mellom et forsikringsselskap og en bank. At Høyesterett nevner at bankene er «profesjonelle aktører som ikke vil komme i vesentlige problemer ved en tilbakebetaling», kan neppe tas til inntekt for at man legger selvstendig vekt på mottagers profesjonalitet. ${ }^{215}$ I saken var jo både betaler og mottager «profesjonelle», slik at det er vanskelig å se at et generelt hensyn til den profesjonelle part skulle spille inn i den ene, men ikke den andres, favør. I beste fall må uttalelsen kunne tas til inntekt for at mottagers betalingsevne er av relevans. Uten at man har høyesterettspraksis til støtte for dette, kan nok den praksis man har fra sivilombudsmannen og trygderetten gi støtte til et slikt hensyn, se punkt 7.4.2.

\subsection{Oppsummering}

I punkt 6.2 så vi at det foreligger en del momenter som trekkes frem av Høyesterett som relevante i den enkelte sak. Noen av disse momentene, slik som forbehold, subjektive forhold og tidsmomentet, blir kommentert i de fleste saker. Selv om det er vanskelig å uttale seg generelt om rekkevidden av konkrete vurderinger, vil nok de momenter som går igjen i en rekke dommer, tillegges betydning generelt. Hvilken vekt de får, er derimot usikkert.

Fra noen av momentene kan det trekkes mer eller mindre klare slutninger, og enkelte tendenser kan gi antydning om momentenes vekt: Forbehold og protest vil normalt tale i betalers favør. Tilsvarende vil det være et tungtveiende argument for tilbakesøkning at betalingen er fremprovosert av tredjemanns svik eller prestert under press eller tvang. Uaktsomhet fra den ene parten vil kunne slå ut i motpartens favør. Samtidig er momentene dårlig egnet for antiteser: Fraværet av et moment i favør av tilbakesøkning, taler ikke nødvendigvis mot tilbakes $\varnothing$ -

\footnotetext{
${ }^{211}$ Ibid. (premiss 44).

${ }^{212}$ Se f.eks. Bergsåker (2015) side 280 og Hagstrøm (2011) side 706.

${ }^{213}$ Se f.eks. folketrygdloven $§ 22-15$, jf. NOU 1990: 20 side 698.

${ }^{214}$ Hagstrøm (2011) side 706.

${ }^{215}$ Rt. 1995 s. 1641 (side 1650).
} 
ning. Tidsmomentet, som gjerne blir fremhevet i teori og praksis, har ikke alene gitt utslag i resultatene i de forskjellige dommene.

\subsection{Utfordringer}

I obligasjonsrettslige fremstillinger har man gjerne listet opp de ulike momenter som er trukket frem i rettspraksis, for deretter å vise til at de i enkeltsaker har slått ut i favør av tilbakebetaling eller nektelse av tilbakebetaling. ${ }^{216}$ En slik fremstilling gir liten generell veiledning for hvordan man bør argumentere ved spørsmål om tilbakesøkning, annet enn å fortelle hvilke momenter som kan tillegges vekt. Stort nærmere et avklart vurderingstema kommer man imidlertid ikke. Denne utilstrekkeligheten med hensyn til å klargjøre vurderingstemaet for helhetsvurderingen, er også påpekt i litteraturen. ${ }^{217}$

Selv om vi i punkt 6.2 og 6.3 kunne trekke enkelte slutninger og peke på enkelte tendenser i rettspraksis, gir heller ikke den fremstillingen som er gjort ovenfor, grunnlag for å utlede et klart vurderingstema fra rettspraksis. Dette kan ha sin naturlige forklaring $i$ at man ved helhetsvurderinger gjerne kan utlede lite fra den enkelte dom om hvilken vekt det enkelte moment generelt har. Fenomenet kan beskrives som en «black box»-problematikk, hvilket Huser har beskrevet som at «[m]an tar en rekke «tolkningsmomenter» og mater inn i en ikke beskrevet prosess (en «black box») og ut kommer på et underfundig vis det ferdige tolkningsresultat». ${ }^{218}$ Den prosessen Huser beskriver for avtaletolkning, har sterke likhetstrekk med helhetsvurderingen ved tilbakesøkning.

Hvis man begrenser seg til Høyesteretts uttalte begrunnelser, kan man fra enkeltsakene ikke utlede et klart vurderingstema for helhetsvurderingen. Knoph advarer mot å fors $ø$ ke å generalisere for mye fra rettspraksis ved rasjonaliseringen av en rettslig standard. ${ }^{219}$ I dette må det først og fremst ligge en erkjennelse av at enhver sak er konkret, hvilket medfører at man ikke nødvendigvis kan se enkeltavgjørelser som prejudikater for hvordan momenter generelt skal vektes. Samtidig viser Knoph til at man ved rasjonaliseringen må kunne benytte seg av andre kilder, slik som enkeltregler i lovene, andre prinsipper og Øvrig praksis, som kan kaste lys over den tankegang standarden bygger på. ${ }^{220}$ Hvorvidt man på bakgrunn av en bredere vurdering kan finne argumenter som er egnet til å presisere vurderingstemaet for helhetsvurderingen, vil jeg undersøke i neste kapittel.

\footnotetext{
${ }^{216}$ Se f.eks. Bergsåker (2015) side 272 flg., særlig side 276, og Hagstrøm (2011) side 705 flg.

${ }^{217}$ Hagstrøm (2011) side 705.

${ }^{218}$ Huser (1983) side 37.

${ }^{219}$ Se Knoph (1939) side 43. Med rasjonalisering siktes her til å presisere og belyse vurderingen standarden gir anvisning på.

${ }^{220}$ Ibid. side 32.
} 


\section{$7 \quad$ Betraktninger rundt helhetsvurderingen}

\subsection{Innledning}

Vurderingstemaet for helhetsvurderingen er i sin enkleste form hvorvidt tilbakes $\varnothing$ kning er rimelig eller ei. Dette følger av Høyesteretts mye gjengitte formulering i Rt. 1985 s. $290 .{ }^{221} \mathrm{Vi}$ har i norsk rett ingen uttalt hovedregel om hverken å innrømme eller nekte tilbakesøkning. For å avgjøre hvorvidt tilbakesøkning skal skje, må man se på alle momentene. Fra momentene kan man i beste fall slutte at betalingen bør bestå eller korrigeres. Disse to slutningene kan sorteres under oppgjørshensynet og korreksjonshensynet. Sagt med Høyesteretts ord: «feil bør rettes opp - korreksjonshensynet, og ting bør forbli som de er - oppgjørshensynet.» ${ }^{222}$ Som uttalelsen illustrerer, gir ikke disse navnene særlig veiledning.

Som vist i kapittel 6, kan man ikke ut fra Høyesteretts uttalte begrunnelse utlede et klart argumentasjonsmønster for helhetsvurderingen. Momentene gir ikke en felles forklaring på de resultater man er kommet til; noen ganger foreligger momentene, noen ganger foreligger de ikke, andre ganger foreligger argumenter mot å tillegge momentet vekt i den konkrete saken. I dette kapittelet vil jeg undersøke om det innenfor rammen av Høyesteretts praksis er mulig å presisere vurderingstemaet for helhetsvurderingen. For å finne argumenter for hvordan vurderingstemaet $b \phi r$ forstås, vil jeg derfor også lete etter svar i andre kilder enn høyesterettspraksis. Dermed er vi utenfor en ren de lege lata-fremstilling. Samtidig går jeg ikke over i en ren de lege ferenda-drøftelse: Det jeg vil finne frem til nedenfor, er en systematikk innenfor rammen av gjeldende rett. Jeg vil altså se på argumenter, løsninger og systematikk som er relevant og som kan tillegges vekt innenfor rammen av helhetsvurderingen.

Når man foretar en vurdering med normative innslag, vil de hensynene man bygger på, farge den tilnærmingen man har til kildene. Når jeg i det videre skal undersøke om man kan utlede noen retningslinjer for vurderingstemaet i norsk rett, utover det Høyesterett eksplisitt gir uttrykk for, vil særlig hensynet til forutberegnelighet stå sentralt. Etter gjeldende rett er vurderingstema for helhetsvurderingen uklart. Hva som oppfattes som rimelig, vil kunne avhenge av hvem man spør. Selv om rettspraksis gir en viss veiledning, løper partene en betydelig prosessrisiko i saker hvor vurderingstemaet er uavklart. Når jeg oppstiller forutberegnelighet for partene som et sentralt hensyn, medfører dette at jeg i søken etter retningslinjer for vurderingstemaet vil fors $\emptyset$ ke å finne frem til løsninger som er klare og objektive, og dermed egnet til å la partene forutberegne sin rettsstilling. Også der det kommer til tvist, vil et mer presist

\footnotetext{
${ }^{221}$ Rt. 1985 s. 290 (side 294).

222 Rt. 2008 s. 738.
} 
vurderingstema gi retningslinjer for partenes argumentasjon og rettsanvenderens vurdering, hvilket kan bidra til en forenklet prosess.

Helt generelle og firkantede regler vil være best egnet til å fremme forutberegneligheten. Imidlertid vil det kunne medføre svært urimelige utslag i den enkelte sak dersom reglene blir for «firkantede». Hensynet til forutberegnelighet må derfor avveies mot hensyn til konkret rimelighet når man skal søke å presisere vurderingstemaet. Samtidig vil den konkrete rimeligheten kunne gå på bekostning av generell rimelighet, dersom konsekvensen er at fravær av forutberegnelighet medfører at personer ikke tør å ta sakene sine til domstolene. Når jeg forsøker å presisere vurderingstemaet, må jeg derfor undersøke om reglene gir en generelt sett rimelig løsning. Hensynet til den konkrete rimelighet vil man ofte kunne ivareta ved unntaksbestemmelser som sikrer mot de mest urimelige resultatene.

Som nevnt er hensikten også i denne delen å skissere et vurderingstema innenfor rammene av gjeldende rett. Dermed vil Høyesteretts praksis være en sentral rettskilde. Men i denne delen av avhandlingen vil også juridisk litteratur, både norsk og utenlandsk, og reelle hensyn utgjøre sentrale kilder til argumentasjonen. Særlig vil jeg se til de løsninger som er valgt i utenlandsk rett, og til løsninger man kan finne på spesielle rettsområder i norsk rett. Erfaringer derfra kan gi inspirasjon til gode generelle løsninger, og de argumentasjonsmønstre man finner i ulike kilder, kan gi veiledning for vurderingstemaet ved ulovfestet tilbakesøkning.

Nedenfor ser jeg først på hovedtrekkene i svensk, fransk og engelsk rett på området. I alle disse landene har man en hovedregel om tilbakesøkning. Fra denne hovedregelen gjøres enkelte unntak fra tilbakesøkning, hvor tilbakesøkning helt eller delvis nektes. Deretter vil jeg undersøke om det er hensiktsmessig også å oppstille en hovedregel om tilbakes $\varnothing$ kning i norsk rett, og hvilke forhold som eventuelt kan begrunne unntak fra denne hovedregelen.

\subsection{Hovedtrekk i utenlandsk rett}

\subsubsection{Svensk rett}

I svensk rett kommer læren om condictio indebiti til anvendelse på «misstagsbetalningar». Grunnvilkåret er at betalingen er «utan rättsgrund». ${ }^{223}$ Der læren om condictio indebiti kommer til anvendelse, er hovedregelen at den som har betalt, har krav på å få tilbake beløpet. Denne hovedregelen er gjenstand for en rekke modifikasjoner som følge av «[a]vvägningen av de motstående interessen som gör sig gällande». ${ }^{24}$ Etter at Hult kom med sitt bidrag til

\footnotetext{
${ }^{223}$ NJA 2011 s. 739 (domskälen punkt 8).

${ }^{224}$ Ibid. (domskälen punkt 7).
} 
rasjonalisering av condictio indebiti for 70 år siden, ${ }^{225}$ har Högsta domstolen inntatt en aktiv rolle i å avklare og presisere vurderingstemaet ved avveiningen av disse motstående interessene. For at man skal kunne nekte tilbakesøkning, må mottageren ha vært i god tro og ha innrettet seg. ${ }^{226}$ I tillegg har man i nyere praksis uttalt at selv der disse to kumulative unntaksvilkårene er oppfylt, må nektelse fremstå som rimelig etter en «övergripande intresseavvägning». ${ }^{227}$ Man står altså overfor en vurdering i tre ledd.

Den gode troen forutsetter at mottager med grunn har gått ut ifra at han var berettiget til å motta betalingen. ${ }^{228}$ Ved vurderingen av hvorvidt mottager var i god tro, kan forhold som betalingens størrelse, forbehold fra betaleren og om den gode troen skyldes rettsvillfarelse, være relevant. ${ }^{229}$ Med hensyn til unnskyldelig rettsvillfarelse viser Högsta domstolen i nyere avgjørelser at dette ikke nødvendigvis vil frarøve mottageren hans gode tro. ${ }^{230}$ Den gode troen må være aktsom («befogad god tro»). For at aktsomhetskravet skal være oppfylt, forutsettes «kunskapsinhämtandet och behandlingen av den kunskap som finns eller borde ha funnits». ${ }^{231}$ Denne vurderingen må gjøres konkret. Momenter som vil kunne ha betydning er hvem som er betaler, herunder om mottager kunne vente betaling fra vedkommende, hvem som er mottager, en forbruker eller en profesjonell, betalingens størrelse og hvorvidt betalingen lot seg forklare for mottager av andre grunner enn en feilbetaling. ${ }^{232}$

Innrettelseskravet innebærer at mottageren må ha tilpasset seg den økonomiske situasjon som han trodde å befinne seg i som følge av feilbetalingen. ${ }^{233}$ Innrettelsen må være i god tro, og dersom mottager ikke har utvist tilstrekkelig aktsomhet, kan ikke innrettelse begrunne nektelse av tilbakesøkning. ${ }^{234}$ Innrettelse omfatter tilfeller hvor beløpet er forbrukt eller mottageren på annen måte har innrettet seg. ${ }^{235}$ Den typiske innrettelse vil være ved at mottageren faktisk har forbrukt de mottatte midlene i god tro. ${ }^{236}$ Mot dagens tilnærming til innrettelsesvurderingen hevder Ingvarsson at man i praksis ikke i særlig grad foretar en undersøkelse av om

\footnotetext{
${ }^{225}$ Hult (1947).

${ }^{226}$ Se NJA 2011 s. 739 (domskälen punkt 7) og NJA 2015 s. 1072 (domskälen punkt 12).

${ }^{227}$ NJA 2015 s. 1072 (domskälen punkt 13).

${ }^{228}$ Lindskog (2018) side 829.

${ }^{229}$ Ibid. side $830 \mathrm{flg}$.

${ }^{230}$ NJA 2015 s. 1072.

${ }^{231}$ Lindskog (2018) side 833.

${ }^{232}$ Ibid side 833-834.

${ }^{233}$ Ibid. side 836.

${ }^{234}$ NJA 2005 s. 142 (side 166).

${ }^{235}$ NJA 2011 s. 739 (domskälen punkt 7).

${ }^{236}$ Lindskog (2018) side 838.
} 
verdiene faktisk er forbrukt, eller om midlene bare er integrert i mottagers økonomi. ${ }^{237}$ I så fall risikerer man at mottager sitter igjen med en netto berikelse som følge av feilbetalingen.

Ingvarsson hevder at det som faktisk gjøres i de fleste condictio indebiti-tilfellene i svensk rett, er at domstolen foretar en godtrovurdering, hvor innrettelsen inngår som et element. ${ }^{238}$ I de tilfeller det faktisk foretas en innrettelsesvurdering, mener han at dette handler om å identifisere ytre kjennetegn på en persons tillit til at en rettshandling skal bestå, hvilket ikke bestandig er nødvendig eller mulig. ${ }^{239}$ Innrettelsen blir simpelthen er et navn «på en förlitan på att förhållandena skall bestå». ${ }^{240}$ Ingvarssons tilnærming er imidlertid kritisert av Lindskog som mener Ingvarsson ikke i tilstrekkelig grad tar hensyn til Högsta domstolens praksis. I tillegg kritiserer Lindskog Ingvarsson for å legge for mye vekt på «psykologisk» innrettelse, hvilket ikke stemmer overens med at innrettelseskravet i praksis har vært ansett oppfylt også der mottager overhodet ikke har hatt noen forestilling om sin formuesforøkning, se NJA 2016 s. $1074 .^{241}$

Hvilke andre disposisjoner enn forbruk som er å anse som innrettelse, følger ikke av en generell regel, slik at man tilsynelatende må argumentere på bakgrunn av de tilfeller som finnes i rettspraksis. Et eksempel fra rettspraksis er at midlene er inntatt i årsregnskap. ${ }^{242}$ Dermed er ikke en «begränsad återbetalningsförmåga [...] en nödvendig förutsätning för att ett relevant inrättande skal anses ha skett». ${ }^{243}$ Med andre ord er det ikke krav om at mottager vil lide $\varnothing$ konomisk tap ved tilbakesøkningen. I motsetning til i engelsk rett har man i svensk rett ikke i praksis lagt til grunn delvis tilbakesøkning, der mottager i noen grad har innrettet seg, men fortsatt sitter med en berikelse. ${ }^{244}$ Svensk rett opererer altså med en «enten eller»-tilnærming.

Lindskog viser til at innrettelsesvurderingen kan innebære «ett hänsynstagande till olika faktorer.» ${ }^{245}$ Han viser særlig til at tiden som er gått, kan få betydning for vurderingen; jo lengre tid som er gått, jo større grunn finnes «i allmänhet att anse att han har på ett erforderligt sätt inrättat sig som rätt betalingsmottagarar». ${ }^{246}$ Dette gir både inntrykk av at tiden i seg selv gir grunn til å presumere innrettelse, og at spørsmålet om innrettelse er knyttet til troen på at man har rett på pengene, og ikke faktiske innrettelseshandlinger. Imidlertid skriver han like etterpå at lang tid likefullt ikke an anses som «något slags självstendigt uttryck för ett inrättande». ${ }^{247}$

\footnotetext{
${ }^{237}$ Se Ingvarsson (2016), se særlig side 54.

${ }^{238}$ Ibid. side 70 .

${ }^{239}$ Ibid. side 71. Jeg forstår Ingvarsson som at han med dette mener at også der innrettelsesvurderinger foretas, utgjør de kun et bevismoment for mottagerens gode tro.

${ }^{240}$ Ibid. side 71.

${ }^{241}$ Lindskog (2018) side 836 og 840, se særlig fotnote 3060 og 3073.

242 NJA 2001 s. 353.

${ }^{243}$ Lindskog (2018) side 838-839.

${ }^{244}$ Ibid. side 839-840.

245 Ibid. side 837.

246 Ibid. side 837.

${ }^{247}$ Ibid. side 878 .
} 
For interesseavveiningen er spørsmålet om nektelse likevel ikke skal skje. Det følger av NJA 2015 s.1072 at denne vurderingen må være konkret, og at også andre forhold enn mottagers aktsomhet og innrettelse vil kunne være relevante. ${ }^{248}$ Lindskog antyder at utgangspunktet også ved interesseavveiningen må være graden av innrettelse. Deretter nevner Lindskog en rekke andre hensyn som kan tenkes å spille inn ved vurderingen, slik som hva slags fordring mottager trodde betalingen var en oppfyllelse av, om mottager har krevet betalingen, om man står ovenfor forbrukere eller profesjonelle parter, beløpets størrelse og sosiale hensyn. ${ }^{249}$ Også betalerens aktsomhet fremheves som et moment ved interesseavveiningen, selv om Lindskog presiserer at betalerens aktsomhet i seg selv ikke bør avskjære nektelse der mottager har innrettet seg. ${ }^{250}$ Samtidig følger det av NJA 2011 s. 739, at «vilken av parterna som hade den största möjligheten att bedöma de förhållanden som har inverkat på betalningen samt om någon av parterna har förfarit oaktsamt i samband med betalningen», kan spille inn ved vurderingen av om tilbakesøkning skal skje. ${ }^{251}$ Dermed kan det virke som at det ved interesseavveiningen er rom for en slags relativ uaktsomhetsvurdering.

Det var først i NJA 2015 s. 1072 at interesseavveiningen ble nevnt som et tredje ledd i vurderingen av tilbakesøkning, men som det fremgår av sitatet fra NJA 2011 s. 739 ovenfor, var det også tidligere rom for en viss interesseavveining ved vurderingen. Da man i NJA 2015 s. 1072 kom til at det ikke forelå noen innrettelse, ble det imidlertid ikke foretatt noen interesseavveining. Den eneste dommen hvor en slik interesseavveining er foretatt, er derfor NJA 2016 s. 1074. I dommen uttales generelt at det bør ha betydning at det er tale om en privatperson som feilaktig har betalt til staten. Imidlertid blir det avgjørende for interesseavveiningen at mottager vanskelig kunne oppdaget feilbetalingen, og at betaleren lett hadde kunnet kontrollere at han hadde betalt til riktig konto. ${ }^{252}$ Det var altså betalers uaktsomhet som fikk avgjørende vekt.

Mens man i litteraturen har angitt forholdsvis detaljerte vurderingstema for de ulike spørsmålene, har naturligvis formuleringene i rettspraksis vært mer overordnet. I NJA 2015 s. 1072 oppsummerer Högsta domstolen vurderingstemaet for når tilbakebetaling kan nektes, på følgende måte:

\footnotetext{
${ }^{248}$ NJA 2015 s. 1072 (domskälen punkt 13).

${ }^{249}$ Lindskog (2018) side 840-849.

${ }^{250}$ Ibid. side 843 .

${ }^{251}$ NJA 2011 s. 739 (domskälen punkt 7). Uttalelsen gjelder generelt for vurderingen etter condictio indebiti, og dommen er avsagt før Högsta Domstolen formelt begynte å operere med en interesseavveining som et tredje steg, jf. NJA 2015 s. 1072.

${ }^{252}$ NJA 2016 s. 1074 (domskälen punkt 22-23).
} 
«12. Under vissa förutsättningar får dock betalningsmottagaren behålla betalningsmedlen. Så är fallet om betalningsmottagaren dels har haft befogad anledning att tro att han eller hon hade rätt till de mottagna medlen (godtroskravet), dels i fortsatt befogad god tro har inrättat sig efter detta (inrättandekravet). Av vikt vid bedömningen om godtroskravet är uppfyllt kan t.ex. vara huruvida ursäktlig villfarelse eller ren felskrivning föreligger. När det gäller inrättandekravet är ofta den tid som har förflutit sedan betalningen gjordes av stor betydelse.

13. Utöver de båda nämnda kraven gäller som förutsättning att det vid en övergripande intresseavvägning ska framstå som motiverat att betalaren ska förlora sin återkravsrätt. Vilket av de motstående intressena som förtjänar företräde beror på många faktorer som kan skifta från fall till fall. De förhållanden som ska beaktas vid avvägningen kan också vara andra än de som hänför sig till godtroskravet respektive inrättandekravet.» 253

Som sitatet viser, kan det se ut til at godtrovurderingen og interesseavveiningen i noen grad går over i hverandre. Innføringen av et tredje ledd i form av en interesseavveining er muligens et fors $\emptyset \mathrm{k}$ på å klargjøre disse skillene. Samtidig bærer i alle fall den tilnærmingen til interesseavveiningen som Lindskog gjør rede for i sin bok, preg av en vurdering tett opp til det man kjenner fra norsk rett. ${ }^{254} \mathrm{I}$ så fall kan interesseavveiningen også være egnet til å medføre $\varnothing \mathrm{kt}$ uklarhet ved vurderingen.

\subsubsection{Fransk rett}

I fransk rett er reglene om tilbakesøkning ved feilbetaling etter reformen av Code civil i 2016, plassert i artikkel 1302 flg. Med hensyn til feilbetalinger er i stor grad tidligere rett videreført i de nye bestemmelsene. Litteratur fra før endringene vil derfor for det alt vesentlige fortsatt være relevant. Tilbakes $\varnothing$ kning ved feilbetaling er én av tre typer kvasikontraktuelle forpliktelsesgrunnlag som behandles i lovboken. De andre er uanmodet forretningsførsel og uberettiget berikelse. $^{255}$

Artikkel 1302 oppstiller hovedregelen for feilbetalinger: Enhver betaling forutsetter en gjeld; det som er mottatt uten å ha vært skyldt, er gjenstand for tilbakesøkning. ${ }^{256}$ Grunnvilkåret for tilbakesøkning er altså simpelthen at det er skjedd en overføring uten rettsgrunn. Anvendelsesområde er ikke begrenset til betaling av fordringer, men omfatter også utbetaling av arv, forsikring og så videre. Videre gjelder regelen både for penger og oppfyllelse i ting. ${ }^{257}$ I annet

\footnotetext{
${ }^{253}$ NJA 2015 s. 1072 (domskälen punkt 12-13).

${ }^{254}$ Lindskog (2018) side 836 flg.

${ }^{255}$ Code civil henholdsvis artikkel 1301 og 1303.

${ }^{256}$ Ibid. artikkel 1302 første ledd (min oversettelse).

${ }^{257}$ Bénabent (2017) side 357.
} 
ledd gjøres unntak for frivillig oppfyllelse av «obligations naturelles», altså oppfyllelse av forpliktelser som ikke kan kreves oppfylt rettslig, men som likevel har en «cause» som forhindrer tilbakesøkning. ${ }^{258}$

I teori og praksis er det gjort et skille mellom «indu objectif» og «indu subjectif». Dette skillet følger implisitt av loven, men begrepene benyttes ikke. Indu objectif omfatter de tilfeller hvor det overhodet ikke foreligger noen forpliktelse, mens indu subjectif foreligger der enten mottager har et krav, men betaleren ikke er rette debitor, eller betaleren har en forpliktelse, men mottageren ikke er rette kreditor. ${ }^{259}$

Indu objectif reguleres av hovedregelen i artikkel 1302. Det som er mottatt uten å være skyldt, må tilbakeføres. Med hensyn til hovedregelen blir dermed mottagers gode tro irrelevant. Av rettspraksis følger videre at det ikke har noen betydning for retten til tilbakes $\varnothing$ kning om betaleren har betalt som følge av en feiltagelse eller ei; det er tilstrekkelig at betalingen faktisk savner rettsgrunn. ${ }^{260}$ Står man ovenfor en feilbetaling ved indu objectif, foreligger kun to forsvar som mottageren kan anføre: Det første er at betalingen var gjort med overlegg, hvilket forutsetter at den var frivillig og med kjennskap om at rettsgrunn ikke forelå. ${ }^{261}$ I så fall står betalingen på egne ben. Det andre forsvaret som kan anføres, er at feilbetalingen kan bebreides betaleren, og at mottager vil lide tap som følge av tilbakebetalingskravet. ${ }^{262}$ I så fall kan tilbakebetalingssummen settes ned, jf. artikkel 1302-3 annet ledd.

Indu subjectif kan oppstå i to tilfeller. Det første tilfellet er der betaleren har en plikt, men har oppfylt overfor en som ikke er rette kreditor. I disse tilfellene følger løsningen samme mønster som ved indu objectif. I henhold til artikkel 1302-1 må den som mottar, vitende eller uvitende, noe han ikke har krav på, tilbakeføre det han har mottatt. Det andre tilfellet, der betaleren ikke er rette debitor for mottagerens krav, står man overfor en innfrielse av andres gjeld. Disse tilfellene er regulert i artikkel 1302-2. Av hovedregelen følger at den som ved en feiltagelse eller under press har innfridd andres gjeld, kan kreve tilbakebetaling fra mottageren. I disse tilfellene er retten til tilbakesøkning altså betinget. Det er her opp til betaleren å bevise at han ikke har ment å betale uten forpliktelse. ${ }^{263}$ Selv om betaleren oppfyller vilkårene for tilbakesøkning, foreligger tre mulige forsvar som kan anføres av mottageren: For det første er tilbakesøkning avskåret der mottageren har oppgitt sikkerhet eller annen type bevis for sitt

\footnotetext{
${ }^{258}$ Ibid. side 359-360.

${ }^{259}$ Ibid. side 359.

260 Ibid. side 360

${ }^{261}$ Ibid. side 361 .

262 Ibid. side 361.

${ }^{263}$ Ibid. side 363.
} 
krav, for eksempel et gjeldsbrev, ved mottagelsen, jf. artikkel 1302-2 annet ledd. I slike tilfeller ville mottageren bli dårligere stillet ved en tilbakesøkning, siden han ikke lenger har samme sikkerhet for innfrielse fra rette debitor. ${ }^{264}$ For det annet kan beløpet nedsettes dersom feilbetalingen skyldes betalerens uaktsomhet, jf. artikkel 1302-3 annet ledd, som gjelder tilsvarende for indu subjectif og indu objectif. For det tredje må tilbakesøkning være avskåret der betaleren har vunnet frem med krav om tilbakebetaling fra rette debitor, jf. artikkel 1302-2 annet ledd. Her står man i realiteten ikke ovenfor et forsvar for mottageren, all den stund loven gir uttrykk for valgfrihet for betaleren med hensyn til om han vil rette krav mot mottageren eller rette kreditor. Men der rette kreditor har betalt til betaleren, må denne være avskåret fra å fremme krav mot mottageren.

For beregning av tilbakes $\varnothing$ kningssummen viser artikkel 1302-3 første ledd til de felles reglene for restitusjon i artikkel 1352 til 1352-9. Disse reglene er nye og gir felles regler for restitusjon ved hevning, ugyldighet og annen tilbakesøkning. Hovedtrekket i dette regelverket er at man ved tilbakeføring av penger må restituere den fulle nominelle verdi, med tillegg av eventuell avkastning, jf. artikkel 1352-3. Imidlertid gjøres unntak fra sistnevnte reglen der mottager har vært i god tro, jf. artikkel 1352-7.

Det skillet som i fransk rett gjøres mellom indu objectif og betaling av andres gjeld ved indu subjektiv, bygger på en slags standardpresumpsjon som ligner på det som er sagt i punkt 4.3.2 om betalinger som utgjør selvstendige rettslige disposisjoner. Der betaleren overhodet ikke har hatt noen forpliktelse til å betale til mottageren, legger man til grunn at det er en betaling uten rettsgrunn. Man presumerer at betalingen uansett ikke utgjør en selvstendig disposisjon. Der betaleren har innfridd andres gjeld, legger man derimot til grunn at man har ønsket å disponere som man gjorde, med mindre betaleren kan vise at han presterte ved en feiltagelse eller under press. ${ }^{265}$ Dette gir klare, om enn noe firkantede, regler.

For å ivareta godtroende mottager, særlig ved indu subjectif, hvor det ikke foreligger noen vilkår om feiltagelse eller press, er kravet til aktsomhet hos betaler satt høyt. Selv ved mild uaktsomhet fra betalerens side, kan mottager få begrenset tilbakesøkningskravet i henhold til Code civil artikkel 1302-3 annet ledd, slik at han ikke lider tap. ${ }^{266}$ Derimot finnes ingen alminnelig berikelsesbegrensning for feilbetalinger i fransk rett. En slik regel gjelder imidlertid for uberettiget berikelse, hvor tilbakes $\varnothing$ kningssummen for godtroende mottager er begrenset til den laveste av mottagers berikelse eller betalerens tap, jf. artikkel 1303.

\footnotetext{
${ }^{264}$ Ibid. side 364.

265 Terré (2005) side 1013.

${ }^{266}$ Ibid. side 1015.
} 


\subsubsection{Engelsk rett}

I engelsk rett kan en «mistaken payment», feilbetaling, kreves tilbake under prinsippet om «unjust enrichment», uberettiget berikelse. Uberettiget berikelse omfatter krav om tilbakes $\varnothing \mathrm{k}-$ ning som ikke bygger på løfte eller ansvarsbetingende adferd. ${ }^{267}$ For at betaler skal kunne kreve tilbakes $\emptyset$ kning etter prinsippet om uberettiget berikelse, må tilbakesøkningskravet falle inn under en av de såkalte «unjust factors», som utgjør typetilfeller av når en berikelse er uberettiget. ${ }^{268}$ Feilbetaling utgjør en slik «unjust factor» og gir dermed adgang til tilbakes $\varnothing \mathrm{k}$ ning. ${ }^{269}$

I teorien forfektet Birks et synspunkt hvor de såkalte «unjust factors» var overflødige, fordi «absence of basis» (fravær av rettsgrunn) i seg selv medførte at berikelsen var uberettiget. ${ }^{270}$ Et slikt syn er likevel foreløpig ikke akseptert i rettspraksis slik at man fortsatt må bygge kravet på at tilfellet faller innenfor en av de såkalte «unjust factors». ${ }^{271} \mathrm{Da}$ denne avhandlingen kun omhandler feilbetalinger, går jeg ikke videre inn på denne metodiske uenigheten.

Feilbetaling er ansett som kjernetilfellet av uberettiget berikelse. ${ }^{272}$ Dersom en mottager har blitt beriket på betalerens bekostning som følge av en feilbetaling, har mottager oppnådd en uberettiget berikelse, og betaler har i utgangspunktet et krav på å få mottagers berikelse tilbakebetalt. ${ }^{273}$ For å avgjøre hvorvidt en «mistake» medfører en «mistaken payment», er spørsmålet om det foreligger en årsakssammenheng mellom feilen og betalingen. Uavhengig av om feilbetalingen skyldes villfarelse om betalingsplikt eller faktiske forhold, kan betalingen i utgangspunktet kreves tilbake hvis «the mistake caused the enrichment to be transferred». ${ }^{274}$ Feilen må altså ha ledet til betalingen.

Vilkåret om «mistake» innebærer at fraværet av forpliktelse ikke i seg selv gir grunnlag for tilbakesøkning. Tilfeller hvor retten til tilbakesøkning er utelukket grunnet fravær av feil, omfatter tilfeller hvor betaleren betalte til tross for tvil med hensyn til betalingsplikten. ${ }^{275}$ Også der det foreligger en gyldig betalingsforpliktelse, men selve oppfyllelsen skyldtes en feiltagel-

\footnotetext{
${ }^{267}$ Virgo (2015) side 2105.

${ }^{268}$ Test Claimants FII Group Litigation v Revenue and Customs (avsnitt 162).

${ }^{269}$ Woolwich v Inland Revenue (side 172).

${ }^{270}$ Birks (2005) side 101-160, særlig side 160.

${ }^{271}$ Test Claimants FII Group Litigation v Revenue and Customs (avsnitt 162).

${ }^{272}$ Se Birks (2005) side 3 og Burrows (2012) side 64.

${ }^{273}$ Dette følger av Burrows (2012) punkt 1 (1)-(2), jf. punkt 10 (1). For henvisninger til oversikten i Burrows fremstilling på side 1-25, vil jeg referere til punktene. For Burrows kommentarer vil det bli henvist til sidetall. Burrows fremstilling er en «Restatement»som i all hovedsak en fremstilling av gjeldende rett, med enkelte kommentarer som går lenger enn hva som direkte kan utledes av rettspraksis. Boken er skrevet $\mathrm{i}$ samarbeid med en rekke engelske jurister, professorer og dommere, herunder to høyesterettsdommere.

${ }^{274}$ Virgo (2015) side 2120.

${ }^{275}$ Ibid. side $2121 \mathrm{flg}$.
} 
se, er tilbakesøkning utelukket. ${ }^{276}$ Andre grunner som avskjærer tilbakesøkning, vil være der betalingen må anses som et forlik eller en ettergivelse og der tilbakebetaling vil krenke hensyn bak offentlig lovgivning. ${ }^{277}$ Rettsvillfarelse er derimot ikke lenger i seg selv til hinder for tilbakesøkning. ${ }^{278}$ Heller ikke at betaleren har opptrådt uaktsomt, medfører at krav om tilbakesøkning er tapt. Allerede av eldre rettspraksis om tilbakesøkning av feilbetalinger følger at kravet er i behold «however careless the party paying may have been in omitting to use due diligence to inquire into the fact». ${ }^{279}$

Den engelske hovedregelen kan altså oppsummeres til at der betaleren ved en feiltagelse har betalt noe han ikke skyldte, er mottageren blitt uberettiget beriket. Feiltagelsen behøver ikke innebære en villfarelse om betalingsplikt; det er tilstrekkelig at feiltagelsen faktisk medførte at det ble betalt uten forpliktelse. Der en feilbetaling medfører en uberettiget berikelse, skal den etter hovedregelen tilbakeføres. Dette er ikke opp til domstolenes skjønn, men et rettskrav:

«A claim to recover money at common law is made as a matter of right; and even though the underlying principle of recovery is the principle of unjust enrichment, nevertheless, where recovery is denied, it is denied on the basis of legal principle.» ${ }^{280}$

Imidlertid følger enkelte forsvar som mottageren kan anføre. ${ }^{281}$ Det viktigste forsvaret, som er av særlig betydning ved feilbetalinger, er såkalt «change of position». Kjernen i dette forsvaret er at den som har innrettet seg i god tro på en betaling, ikke skal lide tap ved å måtte betale tilbake mer enn den berikelsen han har i behold når kravet fremmes. Forsvaret bygger altså på at det vil være urimelig å kreve mottageren for hele beløpet:

«[W]here an innocent defendant's position is so changed that he will suffer an injustice if called upon to repay or to repay in full, the injustice of requiring him so to repay outweighs the injustice of denying the plaintiff restitution. If the plaintiff pays money to the defendant under a mistake of fact, and the defendant then, acting in good faith, pays the money or part of it to charity, it is unjust to require the defendant to make restitution to the extent that he has so changed his position.» ${ }^{282}$

\footnotetext{
276 Ibid. side $2123 \mathrm{flg}$.

${ }^{277}$ Ibid. side 2125.

${ }^{278}$ Kleinwort v Lincoln City.

${ }^{279}$ Kelly v Solari (punkt 59).

${ }^{280}$ Lipkin Gorman v Karpnale (side 578).

${ }^{281}$ De $\varnothing$ vrige forsvarene er angitt i Burrows (2012) punkt 24-33.

${ }^{282}$ Lipkin Gorman v Karpnale (side 579).
} 
Regelen om «change of position» tar først og fremst sikte på «disenrichment», altså tap av berikelse. ${ }^{283}$ Den som er blitt beriket, er pliktig å betale tilbake. Berikelsen er i utgangspunktet det mottatte. Men den som i godtroende innrettelse etter berikelsen har gjort disposisjoner som vil medføre at tilbakebetaling av hele summen i realiteten vil stille ham dårligere enn om pengene aldri var mottatt, kan anføre at det ikke lenger er noen berikelse i behold. Samtidig vil ikke ethvert forbruk av de mottatte midlene medføre en «change of position». ${ }^{284}$ Det må være snakk om disposisjoner som man ikke ellers ville gjort, og som medfører at den netto berikelsen blir negativ dersom mottager må tilbakeføre hele beløpet. Det klassiske eksempelet er at noen har mottatt et beløp i god tro og finner ut at de har mer penger enn de trodde, og derfor gjør en donasjon til veldedighet som de ellers ikke ville gjort. ${ }^{285}$ Dersom mottager etterpå skulle blitt krevet for hele beløpet, ville han sittet igjen med et netto tap som følge av donasjonen han hadde gjort i tillit til berikelsen. «Change of position» innebærer altså at tilbakesøkningssummen skal begrenses til den berikelsen som er i behold.

At de mottatte midlene har blitt sammenblandet med andre midler og brukt til alminnelige utgifter som mottager måtte betalt uavhengig av berikelsen, er ikke tilstrekkelig til at det er skjedd en «change of position». Der mottageren har satt penger på sparekonto eller gjort investeringer, og pengene er i behold, vil det ikke ha skjedd noen «change of position». Har mottageren gjort investeringer i andre ting, for eksempel ved å bruke hele beløpet til å pusse opp badet, må det ved vurderingen av tapet tas hensyn til den gevinsten mottageren har oppnådd ved et nytt bad. Skulle tilbakesøkning fullt ut nektes på grunn av «change of position», vil mottager i disse tilfeller sitte igjen med en netto berikelse i form av et nytt bad. Løsningen må derfor være at tilbakesøkningskravet fører frem, men at summen begrenses oppad til den bevart berikelse mottageren sitter igjen med. Denne vil her utgjøre verdien av det nye badet. $^{286}$

Forsvaret om «change of position» er generelt. Imidlertid er det en forutsetning at mottager ikke var i ond tro («bad faith»). Ond tro sikter her først og fremst til tilfeller hvor mottager har opptrådt «dishonest» ved at han visste eller valgte å holde seg uvitende om at han ikke hadde rett til pengene. ${ }^{287}$ Der mottager «[has] allowed himself to be blinded to what should have been obvious to him», kan han altså ikke hevde å være i god tro. ${ }^{288}$ Alminnelig uaktsomhet, «negligence», er derimot ikke omfattet av «bad faith», og mottager kan også i disse tilfellene

\footnotetext{
${ }^{283}$ Birks (2005) side 208 flg.

${ }^{284}$ Virgo (2015) side 2233.

285 Ibid. side 2233.

${ }^{286}$ Burrows (2012) side 118-119.

${ }^{287}$ Birks (2005) side 214.

${ }^{288}$ Harrison v Madejski (avsnitt 61).
} 
innrette seg og benytte seg av forsvaret. ${ }^{289}$ Også der mottager «[has] failed to make inquiries which a reasonable person would have realised should be made», vil han være i god tro, såfremt «[he] did not suspect that there were reasons why the claimant might have a claim for restitution». ${ }^{290}$ Men en nedre grense for hvilken grad av uaktsomhet som kan aksepteres før mottager ikke lenger anses for å være i god tro, må trekkes der han har «good reason to believe that there are facts which enable the claimant to claim restitution.» ${ }^{291}$

Dersom mottager ikke er i «bad faith», er det irrelevant om mottager har vært mer uaktsom enn betaleren. Man opererer altså ikke med en relativ aktsomhetsnorm. Dette er bekreftet i nyere praksis, hvor man har avvist at liten grad av skyld hos betaleren kan være et relevant moment ved utmålingen av tilbakebetalingssummen. ${ }^{292}$

Andre forhold som kan medføre at forsvaret om «change of position» ikke kan anvendes, er at mottager ved disposisjonene var involvert i betydelig kriminell aktivitet eller gjennomførte disposisjoner som innebar risiko med lånte penger, ${ }^{293}$ eller at forholdene som gjør berikelsen uberettiget, er av en slik art at de må veie tyngre enn disposisjonene gjort i tillit til betalingen. ${ }^{294}$ Sistnevnte vil kunne være aktuelt der staten urettmessig har beriket seg, og hvor de ikke kan anføre at berikelsen er tapt grunnet innrettelse. ${ }^{295}$ Der mottager av disse grunner er utelukket fra å anvende forsvaret, må han tilbakebetale hele det mottatte beløpet.

\subsection{Muligheter for en hovedregel}

\subsubsection{Rammene for norsk rett}

Det første man må vurdere, er hvorvidt det er grunnlag for å holde fast ved den tradisjonelle norske oppfatningen om at man overhodet ikke kan oppstille noen form for utgangspunkt, presumpsjon eller hovedregel. ${ }^{296}$ Som vi så ovenfor er utgangspunktet i både svensk, fransk og engelsk rett at feilbetaling som hovedregel gir betaleren et krav på tilbakebetaling. Av nyere rettspraksis er det først og fremst Rt. 1985 s. 290 det vises til som grunnlag for at det ikke kan oppstilles en hovedregel. I dommen uttaler Høyesterett:

\footnotetext{
${ }^{289}$ Se Virgo (2015) side 2236-2237.

${ }^{290}$ Ibid. side 2237.

${ }^{291}$ Ibid. side 2236.

292 Dextra Bank v Bank of Jamaica (avsnitt 45-46).

${ }^{293}$ Burrows (2012) punkt 23 (2) (a).

${ }^{294}$ Ibid. punkt 23 (2) (b).

295 Ibid. side 122.

${ }^{296}$ Bergsåker (2015) side 291.
} 
«Det er et grunnleggende trekk i læren om condictio indebiti at hvert tilfelle skal vurderes konkret og under hensyn til rimelighet.» 297

Uttalelsen er hyppig sitert i rettspraksis som utgangspunktet for vurderingen i feilbetalingstilfellene. Uttalelsen gir klart uttrykk for at det skal foretas en konkret vurdering. Men at det skal foretas en konkret vurdering i den enkelte sak, er ikke i seg selv til hinder for at man kan ha en presumpsjon for det ene eller annet resultat. At Høyesterett i enkelte tilfeller innrømmer tilbakesøkning uten å foreta en omfattende helhetsvurdering, taler for at Høyesterett ikke selv anser uttalelsen å begrense muligheten til å oppstille utgangspunkter for drøftelsen. Det finnes også et eksempel på at Høyesterett har formulert vurderingstemaet for tilbakesøkning som et spørsmål om «det foreligger grunnlag for å nekte tilbakebetaling etter reglene om condictio indebiti». ${ }^{298}$ Denne uttalelsen viser at det ikke prinsipielt er noen motstrid mellom å oppstille en presumpsjon om tilbakesøkning og å bygge på en konkret vurdering. Tilsvarende negative formuleringer av vurderingstemaet, hvor utgangspunktet angis som tilbakes $\varnothing \mathrm{kning}$, finner man eksempler på i underrettspraksis og fra sivilombudsmannen. ${ }^{299}$

Resultatene fra dommene om tilbakesøkning fra de siste 75 årene viser at Høyesterett i overveiende grad har kommet til at tilbakesøkningskrav må føre frem. I tretten saker kom Høyesterett til at tilbakesøkningskravet måtte føre frem, ${ }^{300}$ i syv av disse etter en helhetsvurdering, ${ }^{301}$ mens i bare én sak ble tilbakesøkning nektet selv om grunnvilkårene var oppfylt. ${ }^{302}$ Tendensen i høyesterettspraksis er altså at der grunnvilkårene er oppfylt, innrømmes tilbakesøkning. Samtidig finnes ingen dommer hvor Høyesterett tar til orde for en generell hovedregel. Støtte for en slik regel må derfor søkes i andre kilder.

I Rt. 2008 s. 738, se punkt 5.2.1 og 6.2.6, fikk staten som mottager medhold i at det måtte gjøres fradrag i tilbakesøkningskravet for den delen av avgiften som betaleren hadde veltet over på sine kunder. Denne vurderingen var gjort delvis etter analogier fra læren om condictio indebiti. Det var imidlertid ikke bestridt at mottager i utgangspunktet hadde krav på tilbakebetaling. Et slikt krav, i prinsipp, fulgte av EU-retten. Dommen er derfor ikke et eksempel på at tilbakesøkningskravet som sådan har blitt nektet etter en helhetsvurdering.

\footnotetext{
${ }^{297}$ Rt. 1985 s. 290 (side 294).

298 Rt. 1997 s. 1210 (side 1216).

${ }^{299}$ Se SOMB-1997-68 og LH-2010-81939.

${ }^{300}$ Se HR-2016-2491-A, Rt. 2012 s. 722, Rt. 2010 s. 1500, Rt. 2010 s. 816, Rt. 2001 s. 1580, Rt. 1998 s. 989 , Rt. 1997 s. 1210 , Rt. 1995 s. 1641 , Rt. 1988 s. 556, Rt. 1985 s. 290 , Rt. 1979 s. 69, Rt. 1959 s. 1129 og Rt. 1953 s. 1460 .

${ }^{301}$ Se Rt. 2010 s. 816 , Rt. 2001 s. 1580 , Rt. 1998 s. 989, Rt. 1995 s. 1641 , Rt. 1985 s. 290, Rt. 1979 s. 69 og Rt. 1953 s. 1460.

${ }^{302}$ Se Rt. 1997 s. 1029.
} 


\subsubsection{Vurdering}

Ser man først på forutberegneligheten, vil en hovedregel om tilbakesøkning medføre en forenkling av vurderingstemaet og således gi partene bedre forutsetninger for å vurdere egen rettsstilling. En hovedregel om tilbakesøkning medfører at mottager som ikke kan anføre særlige omstendigheter som tilsier at han skal få beholde det urettmessig mottatte beløp, vil ha et incentiv til å betale tilbake i stedet for å gå til retten.

Mot en hovedregel om tilbakesøkning har det tradisjonelt vært hevdet at dette vil svekke betalingsmottagerens tillit til mottatte betalinger og forutberegneligheten i omsetningslivet. ${ }^{303}$ På denne bakgrunn mente blant annet Ussing at retten til tilbakesøkning måtte «holdes indenfor saa snævre Grænser, at der ikke skabes for stor Utryghed». ${ }^{304}$ At man i hovedsak skal kunne stole på at en mottatt betaling er endelig, er jeg enig i. Derimot har resonnementet flere svakheter som argument mot en hovedregel om tilbakesøkning ved feilbetaling. For det første er de fleste betalinger ikke feilbetalinger, og man kan derfor stole på at de aller fleste betalinger er endelige. ${ }^{305}$ For det annet har man på ugyldighetens område akseptert at selv om man som utgangspunkt skal kunne stole på at avtaler skal holdes, kan ugyldighet medføre at avtalen faller bort. At det skal være et større behov for å beskytte tilliten til betalinger enn tilliten til avtaler, kan jeg ikke se. For det tredje er en hovedregel om tilbakesøkning ved feilbetalinger normen i en rekke vestlige land, uten at disse meg bekjent har omfattende problemer med tillit til betalinger av den grunn. ${ }^{306}$ Også i norsk høyesterettspraksis har man i all hovedsak gitt medhold i krav om tilbakesøkning, uten at dette kan sies å ha medført at folk ikke lenger kan stole på en mottatt betaling.

Generelle rimelighetsbetraktninger kan gi støtte til en hovedregel om tilbakes $\varnothing$ kning av feilbetalinger. Den som har mottatt noe han ikke har krav på, bør i utgangspunktet gi det tilbake til rette eier. Lindskog trekker inn en lignende rettspolitisk begrunnelse for hovedregelen i svensk rett, nemlig at «[e]n rättsordning som utgår från att den som av en tillfällighet tar emot en betalning utan att ha någon rätt till denna får behålla betalningsmedlen är ägnad att skapa en befogad skeptisk inställning bland medborgarna». ${ }^{307}$ Birks illustrerer begrunnelsen for et

\footnotetext{
${ }^{303}$ Ørsted (1930) side 276-277.

${ }^{304}$ Ussing (1946) side 433.

305 Se tilsvarende kritikk av Ørsteds lære hos Hult (1947) side 251.

${ }^{306}$ Dette poenget er også nevnt i Hagstrøm (2011) side 704. Både i fransk rett, jf. Code civil artikkel 1302, i svensk rett, jf. NJA 2011 s. 739 (på side 749), i engelsk rett, se bl.a. Burrows (2012) side 5, jf. side 63, i tysk rett rett, jf. BGB $\S 812$, og i sveitsisk rett, jf. Code des obligations artikkel 63, er hovedregelen at tilbakebetaling skal skje.

${ }^{307}$ Lindskog (2018) side 825.
} 
utgangspunkt om tilbakesøkning med et eksempel fra hverdagslivet: Har du mottatt for mye veksel av ekspeditøren, må du selvfølgelig gi pengene tilbake. ${ }^{308}$

Systembetraktninger og hensynet til koherens i lovverket tilsier også en hovedregel om tilbakesøkning. En slik hovedregel setter tilbakesøkning ved feilbetaling på linje med tilbakesøkning ved ugyldighet og tinglige tilbakesøkningskrav. ${ }^{309}$ Også her har man utgangspunkt om tilbakesøkning, hvor nektelse må begrunnes. ${ }^{310}$

Et eksempel på at man har etablert en klar hovedregel om tilbakeføring ved feilbetaling, har man i folketrygdloven. I folketrygdloven $\S 22-15$ oppstilles en hovedregel om tilbakebetaling, mens det $\mathrm{i}$ bestemmelsens fjerde og femte ledd gis retningslinjer for vurderingen av når tilbakesøkning skal nektes eller begrenses. Dette bidrar til forutberegneligheten ved å gi definerte utgangspunkter for når tilbakebetaling skal skje, og når det kan være aktuelt å nekte tilbakesøkning.

Det som er sagt ovenfor om et utgangspunkt om tilbakes $\emptyset$ kning, rokker ikke ved den norske tilnærmingen om at spørsmål om tilbakesøkning må avgjøres etter en konkret vurdering. Dersom mottager har vært i god tro, må det fortsatt foretas en konkret vurdering for å se om tilbakesøkning likevel må nektes. A oppstille en hovedregel om tilbakesøkning der det har skjedd en betaling uten rettsgrunn, innebærer således ikke mer enn at man sier at det får være opp til mottager å begrunne hvorfor betalingen ikke skal tilbakeføres. En slik tilnærming følger hovedlinjene i svensk rett, hvor man anser condictio indebiti som en «motregel». ${ }^{311}$ Da blir vurderingstemaet ikke hvorvidt tilbakesøkning skal føre frem eller ei, men et spørsmål om «vad som kan motivera ett undantag från den regeln [tilbakesøkning]». ${ }^{312}$ Hensynet til den konkrete rimelighet vil være ivaretatt nettopp ved at hovedregelen ikke er mer enn en presumpsjon eller et utgangspunkt. Mottageren kan fortsatt ha rett til å beholde pengene dersom han kan anføre grunner som tilsier at tilbakes $\varnothing$ kning bør nektes. Som vi skal se nedenfor, vil unntak og begrensninger i tilbakesøkningsadgangen ivareta mottagers behov for å kunne innrette seg i tillit til en mottatt betaling.

\footnotetext{
${ }^{308}$ Birks (2005) side 6: «The fact remains that, so long as you still have the mistaken money, there is no answer to the shop's demand to have it back.»

${ }^{309}$ Se henholdsvis Hauge (2009) side 346 og godtroervervloven $\S 1$.

${ }^{310}$ For ting er «unntaket» lovfestet i godtroervervloven $\S 1$, hvorav det følger at godtroende mottager i utgangspunktet ekstingverer. Hovedregelen er likefullt tilbakes $\varnothing$ kning; godtroervervloven hjemler kun, dels omfattende, unntak, se Ot.prp. nr. 56 (1976-1977) side 6.

${ }^{311}$ Lindskog (2018) side 821.

${ }^{312}$ Ibid. side 826
} 


\subsection{Muligheter for presisering av vurderingstemaet}

\subsubsection{Innledning}

Høyesterett beskriver vurderingstemaet for condictio indebiti som et spørsmål om «hvem betaler eller mottager - som skal bære den økonomiske risiko ved at det er betalt uten grunnlag i rettslig forpliktelse». ${ }^{313}$ Legger man til grunn en hovedregel om tilbakes $\varnothing \mathrm{kning}$, blir spørsmålet hvilke forhold som kan begrunne at betaleren likevel skal «bære den økonomiske risiko ved at det er betalt uten grunnlag i rettslig forpliktelse».

Ordet risiko gir ikke i seg selv noen veiledning for vurderingstemaet. Uttrykksmåten sier i utgangspunktet ikke mer enn at der betaler har risikoen, får mottager beholde pengene, og der mottager har risikoen, må pengene tilbakebetales. Når en person har risikoen, sier derimot ikke uttrykket risiko noe om; dette må man definere. Ved en hovedregel om tilbakesøkning er risikoen plassert hos mottager. Spørsmålet er hvilke forhold som leder til at risikoen går over på betaleren. Skal vi presisere vurderingstemaet, må vi identifisere disse forholdene.

Nedenfor vil jeg unders $\varnothing$ ke om det er mulig å presisere vurderingstemaet for helhetsvurderingen. Forutsetningen for vurderingen er at vi står overfor en feilbetaling til en mottager som ikke er i positiv ond tro. ${ }^{314}$ Spørsmålet er om tilbakes $\varnothing$ kning bør nektes der mottager har innrettet seg på betalingen, og hvilken betydning mottager og betalers (u)aktsomhet bør ha for spørsmålet om tilbakesøkning. For å finne svar på dette vil jeg se hen til både utenlandsk rett og norsk praksis, lovgivning og teori for argumenter.

\subsubsection{Innrettelse og tap av berikelse}

\subsubsection{Relevans i norsk rett}

Selv om uttrykket «innrettelse» ikke er mye brukt i høyesterettspraksis, ser man i en rekke dommer at hensyn som knytter seg til innrettelse, blir vurdert. Således nevnes i Rt. 1995 s. 1641 som et moment at mottager ikke vil ha problemer med å betale pengene tilbake, ${ }^{315}$ og i Rt. 1985 s. 290 nevnes at et forhold av relevans ville vært om mottageren hadde oppgitt annen sikkerhet for kravet i innrettelse til at betalingen var endelig. ${ }^{316}$ Sistnevnte følger samme linjer som unntaket i fransk rett, jf. Code civil artikkel 1302-2 første ledd, som verner mottager i tilfellene vedkommende ville hatt et gyldig krav mot andre enn betaleren, men har oppgitt sikkerhet i tillit til den første betalingen. Tradisjonelt har spørsmål om innrettelse vært knyttet

\footnotetext{
${ }^{313}$ Rt. 2008 s. 738 (premiss 40).

${ }^{314}$ Se punkt 5.2.2.

${ }^{315}$ Rt. 1995 s. 1641 (side 1650).

${ }^{316}$ Rt. 1985 s. 290 (side 294).
} 
til oppgjørshensynet, og i Rt. 2008 s. 738 benytter Høyesterett betegnelsen «innrettelseshensynet» som synonymt med oppgjørshensynet. ${ }^{317}$

Når jeg behandler innrettelse og tap av berikelse samlet, er dette fordi begge tilnærmingene tar sikte på å verne den godtroende mottager der disposisjoner gjort av mottager i tillit til betalingen, vil medføre at han vil stilles i en dårligere situasjon ved å måtte betale pengene tilbake, enn dersom han overhodet ikke hadde mottatt pengene. Hensynet bak reglene er derfor de samme. Som vi så, operer man i svensk rett med et innrettelseskrav som vilkår for å nekte tilbakesøkning, mens man i engelsk rett ser «change of position» som et spørsmål om utmålingen av tilbakes $\varnothing$ kningssummen. I sistnevnte tilfellet er det altså spørsmål om tilbakesøkningen skal begrenses eller falle bort fordi den opprinnelige berikelsen mottager mottok, er tapt.

At innrettelse inngår som et moment $\mathrm{i}$ helhetsvurderingen i norsk rett, er på bakgrunn av ovennevnte ikke tvilsomt. Spørsmålet nedenfor er om man bør legge vekt på innrettelse og tap av berikelse ved vurderingen av om tilbakesøkning helt eller delvis skal nektes.

\subsubsection{Innrettelse som vurderingstema}

Det viktigste argumentet for å legge vekt på innrettelse ved vurderingen av om tilbakesøkning skal nektes, er at det bare er der mottager har innrettet seg og risikerer å lide tap som følge av tilbakebetalingen, at denne har et reelt beskyttelsesbehov. Mottagers behov for beskyttelse i slike situasjoner er anerkjent både i høyesterettspraksis, lovgivning, underrettspraksis og uttalelser fra sivilombudsmannen. Fra eldre høyesterettspraksis har man også flere eksempler på at man bygger på en berikelsestanke, hvor tilbakesøkning må nektes der ingen berikelse er i behold hos mottageren. ${ }^{318}$

Folketrygdloven har en utfyllende regulering av tilbakebetaling etter feilaktig utbetalinger av stønad, jf. folketrygdloven $§ 22-15$. Der mottager er i aktsom god tro, må tilbakesøkningskravet «begrenses til det beløp som er i behold når vedkommende blir kjent med feilen.» ${ }^{319}$ Ved vurderingen om tilbakesøkning skal kreves overhodet, skal det legges vekt på om «vedkommende har innrettet seg i tillit til den [betalingen].» ${ }^{320}$ Reguleringen i folketrygdloven illustrerer sammenhengen mellom innrettelse og berikelse; der mottager har innrettet seg, tyder dette på at hele berikelsen ikke er i behold, og motsatt tyder fravær av innrettelse på at hele beløpet er i behold og kan tilbakeføres uten at mottager blir satt i en vanskelig situasjon.

Folketrygdloven $\S 22-15$ femte ledd er ment som en videreføring av den tidligere reguleringen i folketrygdloven (1966) $§ 15-8$ annet ledd. ${ }^{321}$ I forarbeidene til denne bestemmelsen var det

\footnotetext{
${ }^{317}$ Rt. 2008 s. 738 (premiss 45).

318 Se Rt. 1934 s. 400 (side 402) og Rt. 1934 s. 33 (førstvoterendes votum).

${ }^{319}$ Folketrygdloven $\S 22-15$ femte ledd.

${ }^{320}$ Ibid. § 22-15 femte ledd.

${ }^{321}$ Ot.prp. nr. 76 (2007-2008) side 84.
} 
uttalt, med hensyn til rimelighetsvurderingen, at tilbakes $\varnothing$ kning ofte vil være urimelig da ytelsene «ligger på et slikt nivå at de aller fleste vil bruke opp ytelsene etter hvert som de blir utbetalt.» ${ }^{322}$ Det man her tar hensyn til, er at mottager vil «rätta munnen efter matsäcken», ${ }^{323}$ slik at man på tross av en opprinnelig berikelse ikke vil sitte igjen med noen netto berikelse når kravet fremmes. Skulle tilbakesøkning innrømmes i slike tilfeller, ville altså mottager sitte igjen med et netto tap som følge av en feilbetaling som ikke skyldtes ham selv.

En rekke uttalelser fra sivilombudsmannen om tilbakesøkning av for mye utbetalt lønn trekker i retning av at innrettelse bør kunne være et sentralt moment ved vurderingen om tilbakes $\varnothing \mathrm{k}$ ning skal nektes. ${ }^{324}$ Om behovet for å verne godtroende mottager som har forbrukt det feilaktig mottatte beløp, har sivilombudsmannen uttalt at «[f]or folk flest i sin alminnelighet og vanlige lønnsmottakere i særdeleshet vil pengebeløp i vanlig størrelsesorden og som er lønn for utført arbeid, gå med til daglig forbruk». ${ }^{325}$ At hensynet til innrettelse kommer inn med særlig tyngde i saker angående lønn, illustreres ved at man i samme uttalelse i en viss grad fant grunn til å bebreide mottageren, men likevel mente at mottageren burde få beholde pengene. I denne sammenheng ble det vist til at man forutsatte at mottageren ikke hadde blitt sittende igjen med noen berikelse. Samtidig viser en uttalelse fra 2009 at det er grenser for hvor stor uaktsomhet som kan tillates fra mottager før innrettelsen mister sin betydning som argument for nektelse. Da mottager «neppe [kunne] sies å ha vært i aktsom god tro», burde pengene kunne kreves tilbake, selv om beløpet på 65.000 kroner måtte antas å være forbrukt. ${ }^{326} \mathrm{En}$ annen uttalelse som illustrerer betydningen av innrettelse kom i 2015, hvor det for flere av de omhandlede arbeidstagerne ble lagt vekt på at det feilaktig mottatte var forbrukt, og mottagerne ville måtte ta opp lån for å tilbakebetale de mottatte beløpene. ${ }^{327}$

Også fra lagmannsrettene har man flere eksempler på at innrettelse oppstilles som det sentrale vurderingstemaet for om tilbakesøkning skal nektes. I LH-2010-81939 konstaterte lagmannsretten først at pengene var forbrukt av mottager, men viste like etter til at de «ikke egentlig [var] forbrukt». ${ }^{328}$ Pengene var brukt til å betale eksisterende forpliktelser hos mottager. Tilbakebetaling ville derfor ikke medføre at mottager ble dårligere stilt enn om beløpet aldri var

\footnotetext{
322 NOU 1990: 20 side 698.

${ }^{323}$ Hult (1947) side 251.

324 Tilbakesøkning av feilbetalt lønn som skyldes forhold hos arbeidsgivers, skal løses etter de «ulovfestede regler om tilbakesøking av erlagt ytelse (condictio indebiti)», jf. Ot.prp. nr. 50 (1993-1994) side 144. Uttalelser fra sivilombudsmannen kan derfor gi relevante argumenter for hvordan man generelt bør ta stilling til tilbakesøkning av feilbetalinger.

325 SOMB-1997-68.

${ }^{326}$ SOM-2009-2194.

${ }^{327}$ SOM-2015-1834.

${ }^{328}$ LH-2010-81939 (min kursivering).
} 
mottatt. Resultatet ble derfor at tilbakesøkning ikke kunne nektes. Den konkrete innrettelsesvurderingen som lagmannsretten her gjorde, følger samme linjer som ved «change of position» i engelsk rett. Et annet eksempel på at innrettelse oppstilles som det sentrale vurderingstemaet, har man i LB-1999-414. Saken gjaldt feilaktig utbetaling av lønn, og i likhet med uttalelsene fra sivilombudsmannen ovenfor, viste lagmannsretten til at det måtte «legges til grunn at pengene i det vesentlige er forbrukt». ${ }^{329}$ Resultatet ble at tilbakes $\varnothing$ kning ble nektet.

Ser man til andre rettsområder, er innrettelse et kjent vurderingstema for norske domstoler. Det siktes her særlig til re integra-regelen som følger analogisk av avtaleloven $§ 39$. Etter denne regelen kan et løfte kalles tilbake dersom løftemottageren ikke har innrettet seg, og det foreligger særlige grunner for å tillate tilbakekall. ${ }^{330}$ I Rt. 2012 s. 1904 foretas en tolkning av innrettelseskravet. Det følger av dommen at den rent psykologiske innrettelsen på at avtalen vil oppfylles, ikke er tilstrekkelig for å konstatere innrettelse. ${ }^{331}$ Dermed må det forutsettes at innrettelsen innebærer en realitet for mottager. I saken var det ikke tilstrekkelig for å konstatere innrettelse at det var avholdt kontraktsmøte, at avtaleutkast var overlevert, eller at forskudd var betalt. ${ }^{332}$ At vilkåret om innrettelse finnes på andre rettsområder, taler for at det kan være egnet til å benyttes også ved feilbetalinger. Videre innebærer det en fordel i form av at man kan anvende praksis fra ulike rettsområder for å definere innholdet i vilkåret.

Hva som nærmere bør kreves for at man skal komme til at mottager har innrettet seg, vil kunne presiseres i rettspraksis, og her trekker jeg derfor bare opp noen linjer. Utgangspunktet bør være tap av berikelse. Det er i disse tilfellene mottager risikerer å lide tap. Også innrettelse i form av oppgivelse av sikkerhet for kravet, der mottager har fått betalt av feil betaler, bør omfattes. ${ }^{333}$ Her er det $\mathrm{i}$ alle fall tale om et potensielt tap for mottager ved å tilbakebetale. Der mottager har investert den opprinnelige berikelsen, er berikelsen i utgangspunktet i behold, slik at tilbakesøkning kan kreves. Men en viss reservasjon må gjøres der mottager har investert i noe han ellers ikke ville. Selv om deler av berikelsen her er i behold, vil verdiene kunne være låst i ting, slik at mottager må ta opp lån for å kunne tilbakebetale. Et eksempel her er mottager som har brukt berikelsen til å pusse opp badet, se eksempelet i punkt 7.2.3. I alle fall der tilbakesøkning vil medføre store utfordringer for mottager med å tilbakebetale, kan det være grunn til å anse innrettelsesvilkåret for oppfylt selv om deler av berikelsen er i behold i

\footnotetext{
${ }^{329}$ LB-1999-414.

${ }^{330}$ Se HR-2017-1782-A (premiss 29 flg.) og Rt. 2012 s. 1904 (premiss 51 flg.).

${ }^{331}$ Rt. 2012 s. 1904 (premiss 53).

332 Ibid. (premiss 56).

${ }^{333}$ Se tilsvarende regel i Code civil artikkel 1302-2 første ledd. En slik regel har støtte i uttalelser fra Rt. 1985 s. 290 (side 294).
} 
låste verdier. Uttalelser fra Rt. 1995 s. 1641 (side 1650), samt SOM-2015-1834, støtter en slik reservasjon der mottager vil ha store problemer med å tilbakeføre det feilaktig mottatte.

De momentene vi kjenner igjen fra helhetsvurderingen, vil kunne sorteres inn under innrettelsesvurderingen. For det første vil tidsmomentet kunne kaste lys over spørsmålet. Der det er gått lang tid fra feilbetalingen til krav fremmes, vil man lettere akseptere at mottager har innrettet seg, eller at beløpet er forbrukt slik at noen berikelse ikke lenger er i behold. Men her må tidsmomentet kun anvendes som et bevismoment. Den tendensen man har i norsk rett til å fremheve tidsmomentet som et sentralt moment, er da ikke heldig. Heller bør man bygge på forståelsen som Høyesterett la til grunn i dommen om re integra fra 2012, slik at det «ikke konstrueres et selvstendig krav om at tilbakekallet må skje innen en nærmere bestemt tidsfrist. Tidsmomentet vil normalt ha betydelig vekt ved vurderingen av grad av innrettelse, og bør etter mitt syn inngå i den vurderingen.» ${ }^{334}$ Siden tidsmomentet her bare har som funksjon å kaste lys over mottagers innrettelse, må hele perioden fra feilbetalingen er mottatt til krav om feilbetaling fremmes vurderes samlet. ${ }^{335}$ For det annet vil betalingens art kunne spille inn ved vurderingen av om mottager må antas å ha innrettet seg. Er det tale om lønn eller ytelser forutsatt til livsopphold, vil det fort måtte legges til grunn at ytelsene er forbrukt. For at innrettelsen skal kunne tillegges avgjørende vekt, må mottager ha vært i god tro gjennom innrettelsen. De forhold som kan kaste lys over god tro ved mottagelsen av betalingen, vil dermed også kunne få betydning for innrettelsesvurderingen.

En vurdering hvor spørsmålet om innrettelse oppstilles som et sentralt vurderingstema for hvorvidt tilbakesøkning skal nektes, ivaretar det mest tungtveiende rimelighetshensynet som i dag henføres under «oppgjørshensynet»: Mottager skal ikke stilles dårligere enn om han aldri hadde mottatt pengene. Ved å oppstille innrettelse som et vilkår for nektelse oppnår man en $\varnothing \mathrm{kt}$ forutberegnelighet og presisering av vurderingstemaet.

\subsubsection{Om begrensning til bevart berikelse}

Dersom mottager har innrettet seg på en slik måte at berikelsen i sin helhet er tapt, vil resultatet av et vilkår om innrettelse og en berikelsesbegrensning bli det samme. Har mottager derimot bare delvis innrettet seg, er spørsmålet om mottager uansett skal tilbakeføre den bevarte berikelsen. ${ }^{336}$ Med en begrensning til bevart berikelse siktes det til den delen av berikelsen som mottager fortsatt har i behold når kravet fremmes. «Berikelsen»sikter her til en begrens-

\footnotetext{
${ }^{334}$ Rt. 2012 s. 1904 (premiss 51).

${ }^{335}$ På denne måten vil også tiden som er gått etter at betaler ble klar over feilbetalingen kunne tillegges vekt ved innrettelsesvurderingen, og ikke bare som et spørsmål om passivitet, se punkt 6.2.5.2.

336 Lilleholt bruker her uttrykket «bevart fordel» for å skille denne typen berikelsesbegrensning fra andre sammenhenger uttrykket «berikelse» brukes i, se Lilleholt (2017) side 487-484, 495.
} 
ning $a v$ kravets omfang til den bevarte berikelsen, og ikke til den opprinnelige berikelsen som grunnlag for kravet. ${ }^{337}$

Noen generell regel om en begrensning til bevart berikelse kan ikke gjenfinnes i Høyesteretts praksis, selv om en slik regel har vært forfektet i litteraturen. ${ }^{338}$ Selv om man i norsk rett ikke har nyere høyesterettspraksis som bekrefter en generell berikelsesbegrensning, er konseptet ikke ukjent i norsk rett. Både reglene i folketrygdloven $\S 22-15$ femte ledd og reglene i vergemålsloven $\S 15$ bygger på at tilbakesøkningskravet skal begrenses til den bevarte berikelsen. ${ }^{339}$ Fra underrettspraksis har man ytterligere eksempler på at det foretas en vurdering av bevart berikelse. ${ }^{340}$

Forsvaret «change of position» i engelsk rett bygger på en «ren» berikelsesbegrensning for feilbetalingstilfellene. Har man her konstatert at mottager ikke er i ond tro, er det ikke lenger rom for noen helhetsvurdering. ${ }^{341}$ Man kan simpelthen konstatere at mottager er blitt uberettiget beriket, og at han derfor har krav på tilbakebetaling. Der grunntanken er at en feilbetaling medfører en uberettiget berikelse på andres bekostning, og man aldri skal berikes uberettiget på andre bekostning, bør betaler alltid få pengene tilbake. Men da det er mottagers berikelse og ikke betalers tap som er gjenstand for tilbakes $\emptyset$ kningskravet, bør beløpet aldri være høyere enn den bevarte berikelsen. Hverken betalerens aktsomhet eller mottagers uaktsomhet kan rokke ved det faktum at berikelsen ikke lenger er i behold. Også i sveitsisk rett, bygger man på en generell berikelsesbegrensning, men her omfatter unntaket for mottager i ond tro også

${ }^{337}$ Denne doble betydningen er påpekt i litteraturen, se Arnholm (1939) side 232 og Lilleholt (2017) side 483484.

${ }^{338}$ Kjønstad skriver at det er «[e]t helt sentralt kjennetegn» ved condcitio indebiti at denne skal begrenses til den bevarte berikelsen, se Kjønstad (2011) side 138. Også Hagstrøm forfekter et utgangspunkt om en berikelsesbegrensning, men påpeker deretter de rettstekniske utfordringene ved en slik regel, og konstaterer at det ikke finnes entydig rettspraksis til støtte for en slik regel, se Hagstrøm (2011) side 710-711. Dette synet er i stor grad en videreføring av det synet som ble forfektet av Augdahl, se Augdahl (1978) side 403. Bergsåker stiller seg derimot kritisk til om det i det hele tatt kan opereres med noen berikelsesbegrensning, og begrunner dette i praktiske utfordringer ved å konstatere om en berikelse er i behold, se Bergsåker (2015) side 285-286. Lilleholt gir uttrykk for at betalingen bør være begrenset til den delen av berikelsen som er i behold, dersom mottager har vært i god tro, se Lilleholt (2017) side 495-496. Berikelsesbegrensningen har lang tradisjon i norsk rett, se Arnholm (1939) side 208-209, med videre henvisninger. Selv stilte Arnholm seg kritisk til en generell berikelsesbegrensning i Arnholm (1939). Senere stiller han seg derimot mer positiv, og gir uttrykk for at berikelsesbegrensningen «er den almindelige oppfatning i norsk rett», se Arnholm (1974) side 164. I alle fall måtte dette være tilfellet der betaler selv tok initiativ til å yte.

${ }^{339}$ Se vergemålsloven $\S 15$, jf. Ot.prp. nr. 110 (2008-2009) side 31.

${ }^{340}$ Se LB-2005-117741 som gjaldt spørsmålet om tilbakebetaling av gevinst som følge av brudd på en konkurranseklausul.

${ }^{341}$ Se omtalen av engelsk rett i punkt 7.2.3. Selv om det ikke er rom for noen helhetsvurdering, foreligger enkelte begrensede unntak fra anvendelsen av «change of position», se Burrows (2012) side 120-122. 
tilfeller der mottager burde ha visst. ${ }^{342}$ Ut over dette er det imidlertid heller ikke i sveitsisk rett plass til noen helhetsvurdering. ${ }^{343}$

I norsk rett anser vi utvilsomt betalers og mottagers (u)aktsomhet som relevante forhold ved vurderingen av tilbakesøkning. Dette innebærer at vi innenfor rammen av helhetsvurderingen ikke bare kan bygge på om berikelsen er i behold eller ei. På den ene siden bygger vi på at mottager hverken skal bli beriket eller lide tap, samtidig bygger vi på at man til en viss grad kan sanksjonere uaktsomhet hos både mottager og betaler med henholdsvis full tilbakes $\varnothing \mathrm{k}-$ ning eller full nektelse. Dette innebærer imidlertid ikke at man ikke kan operere med en berikelsesbegrensning ved utmålingen av tilbakesøkningen også i norsk rett. En slik hybridform ser man i folketrygdloven $\S 22-15$.

En begrensning til bevart berikelse, innebærer at godtroende mottager er beskyttet mot tap, men gir en mer nyansert regel enn den svenske «enten eller»-tilnærmingen. Har mottager først blitt beskyttet mot å tilbakeføre mer enn den berikelsen som er i behold, er det ingen grunn til at mottager, på grunn av delvis innrettelse, skal bli sittende med det resterende beløpet. Heller ikke de bevismessige utfordringene med å fastsette den bevarte berikelsen, er etter mitt syn noe tungtveiende argument mot å operere med en berikelsesbegrensning. Vanskelige vurderinger av både berikelse og tap er man kjent med både fra tilbakesøkningsreglene i folketrygdloven og vergemålsloven, og fra vurderingene av økonomisk tap i erstatningsretten, uten at dette er ansett som en tungtveiende innvending mot reglene der.

\subsubsection{Mottagers aktsomhet}

Graden av aktsomhet som mottager har utvist kan være et relevant moment ved helhetsvurderingen i norsk rett, se punkt 6.2.2.2. Hvilke krav som stilles til aktsomhet ved godtrovurderingen, gir imidlertid rettspraksis ikke noe klart svar på. Man må derfor undersøke andre kilder.

Det reelle hensyn som ligger til grunn for hvorfor man i det hele tatt bør legge vekt på mottagers aktsomhet, er at mottager ikke skal kunne lukrere ved å holde seg i uvitenhet om at han ikke hadde krav på betalingen. Motsatt bør ikke mottager som har innrettet seg i aktsom god tro risikere å bære tap. Har mottager derimot ikke innrettet seg, er det ingen grunn til å legge vekt på aktsomheten. At mottager har opptrådt aktsomt ved mottagelsen, er ingen grunn til å premiere ham med en betalingen han i utgangspunktet ikke hadde krav på.

\footnotetext{
342 Jf. Code des obligations artikkel 64. Se også Tercier (2009) side 374.

${ }^{343}$ Et slikt system er drøftet i kapittel 9, men da som alternativ til den norske modellen med helhetsvurdering.
} 
Aktsomhetsvurderingen er velkjent i norsk rett, og det vil dermed ikke by på særlige utfordringer å innføre et krav om aktsom god tro ved mottagelse og innrettelse, slik som man har i svensk rett. Imidlertid kan det reises innvendinger mot å oppstille et for høyt aktsomhetskrav.

Folketrygdloven $\S 22-15$ oppstiller en todelt regulering. Der mottager er i aktsom god tro skal tilbakesøkning enten nektes eller kravet skal settes ned, jf. folketrygdloven $\S 22-15$ femte ledd. I disse tilfellene kan ikke tilbakesøkningsbeløpet settes høyere enn den berikelsen som er i behold. Er mottager derimot ikke i positiv ond tro, men «burde ha forstått at utbetalingen skyldtes en feil», er hovedregelen at hele beløpet skal tilbakebetales, jf. § 22-15 første ledd. Imidlertid åpner bestemmelsens fjerde ledd for at tilbakesøkning også kan nektes eller settes ned der mottageren var uaktsom, dersom særlige grunner taler for det. For denne vurderingen er blant annet graden av mottagers uaktsomhet av betydning, jf. § 22-15 fjerde ledd annet punktum. Av forarbeidene følger at der feilen skyldes forhold på betalerens side, er det for aktsomhetsvurderingen avgjørende «kor klar eller synleg feilen er, og om vedkomande har vore så aktsam som ein til vanleg kan vente». ${ }^{344}$ Her må det foretas en helhetsvurdering, og det må ses hen til hva mottageren «burde ha forstått dersom han/ho hadde halde seg rimeleg orientert». ${ }^{345}$

Også i uttalelser fra sivilombudsmannen ser man at det ikke stilles særlig høye krav til aktsomheten. I en sak fra 1997 gikk sivilombudsmannen langt i å kritisere mottager for ikke å ha undersøkt lønnsslippene. Men selv om feilen hadde «ligget vel til rette for å bli oppdaget», kom sivilombudsmannen til at tilbakes $\varnothing$ kning ikke burde kreves, da berikelsen var forbrukt. ${ }^{346}$ Det er likevel grenser for hvor stor grad av uaktsomhet som kan tillates. I en sak fra 2009 kom man til at mottager hadde hatt «en klar oppfordring til å undersøke» om betalingen var berettiget, og at tilbakesøkning derfor burde nektes selv om beløpet var forbrukt. ${ }^{347}$

Av ovennevnte ser man at i enkelte tilfeller kan det være betenkelig å stille for høye krav til mottagers aktsomhet. Særlig gjelder dette der betaleren er like mye å bebreide som mottageren. ${ }^{348}$ Stilles aktsomhetskravet for høyt, kan en mottager som ikke selv var klar over at han ikke hadde rett på pengene, men som burde ha gjort større anstrengelser for å avdekke feilbetalingen, risikere å bære tap som følge av sin innrettelse etter en feilbetaling som skyldtes betalers grove uaktsomhet. Stilles aktsomhetskravet derimot for lavt, risikerer man at motta-

\footnotetext{
${ }^{344}$ Ot.prp. nr. 76 (2007-2008) side 11.

345 Ibid.

346 SOMB-1997-68.

${ }^{347}$ SOM-2009-2194.

${ }^{348}$ Lignende betraktninger rundt aktsomhetskravet i godtrovurderingen kan finnes hos Arnholm (1939) side 127129.
} 
gere velger å holde seg uvitende om at de ikke hadde rett på pengene. Folketrygdlovens forarbeider og uttalelsene fra sivilombudsmannen gir her en veiledning på hvilke tilfeller nektelser ikke bør være aktuelt på grunn av uaktsomhet fra mottager.

For vurderingen av om mottager har utvist tilstrekkelig aktsomhet, vil momenter som er kjent fra dagens helhetsvurdering, spille inn. Forbehold og protest vil tale mot at mottager er i aktsom god tro. Der betalingen er fremprovosert av en tredjemann i ond tro, kan mottager risikere å bli identifisert med tredjemann, jf. Rt. 2001 s. 1580. Også beløpets størrelse kan påvirke hvorvidt man bør anse mottager for å være i aktsom god tro. Det vil være lettere å bevise at man har vært i god tro dersom man fikk utbetalt noen hundrelapper for mye i lønn, enn om feilen beløp seg på flere tusen kroner. Det som i kapittel 4 er omtalt som typen av fravær av rettsgrunn, bør også kunne få betydning for vurderingen av mottagers gode tro. Dersom det foreligger komplett fravær av rettsgrunn, bør man lettere kunne komme til at mottager ikke har utvist tilstrekkelig aktsomhet. I disse situasjonene har jo mottager ikke hatt noen forklaring på hvorfor betalingen var mottatt, annet at den måtte være en form for gave. Tilsvarende må gjelde der betaleren har betalt til feil person. Derimot vil man lettere kunne komme til at mottager har vært i aktsom god tro dersom man står overfor en feilbetaling som skyldes at det er betalt av feil person, eller som er følge av en utilstrekkelig rettsgrunn. I disse tilfellene har mottager en berettiget forventning om betaling, og vil normalt ha grunn til å tro på at et mottatt beløp både kommer fra riktig betaler og er i riktig størrelse.

\subsubsection{Betalerens uaktsomhet}

Ser man til Høyesteretts praksis, er det klart at betalers uaktsomhet kan være et moment ved helhetsvurderingen. Som nevnt under punkt 6.2.2.1, har man flere dommer hvor Høyesterett eksplisitt har trukket frem at man ikke finner grunn til å bebreide betaleren. ${ }^{349} \mathrm{I}$ to dommer har det også vært fremhevet at betaleren i noen grad var å bebreide. ${ }^{350}$ Selv om betalers uaktsomhet kan være et relevant moment ved helhetsvurderingen, er det uklart når og i hvilken grad det bør tillegges vekt.

Hensynet bak å legge vekt på betalers uaktsomhet må være at mottager ikke skal risikere å lide tap som følge av at betaleren er skjødesløs med utbetalingene. Dette tilsier at momentet ikke alltid vil være relevant for vurderingen. Der mottager ikke har innrettet seg på berikelsen, er det vanskelig å se noen grunn til at man skal legge vekt på betalerens uaktsomhet; mottager vil ikke her lide tap ved å tilbakeføre betalingen. Dette poenget synes å være erkjent i Rt. 1998 s. 989, hvor man ikke kunne legge vekt på betalers uaktsomhet, da betaleren rettet opp i

\footnotetext{
349 Jf. Rt. 2001 s. 1580 , Rt. 1995 s. 1641 , Rt. 1985 s. 290 og Rt. 1934 s. 400.

${ }^{350}$ Rt. 1998 s. 989 og Rt. 1997 s. 1029.
} 
feilen allerede samme dag. ${ }^{351}$ Dersom man til enhver tid skulle legge vekt på betalerens uaktsomhet, måtte begrunnelsen i så fall være å sanksjonere mot betaleren; noe beskyttelsesbehov har ikke mottager i disse tilfellene. Ser man til fransk rett, hvor betalers bebreidelse er et sentralt grunnlag for nedsettelse av tilbakesøkningsbeløpet, får dette bare betydning i den grad mottager vil lide tap ved tilbakebetalingen, jf. Code civil artikkel 1302-3 annet ledd.

Denne sammenhengen mellom betalerens uaktsomhet og mottagers innrettelse finner man igjen i sivilombudsmannens uttalelser. Ved spørsmål om feilutbetaling av lønn har det i flere saker vært fremhevet at det var grunnlag for å bebreide arbeidsgiver for feilbetalingen og for ikke å ha oppdaget feilen på et tidligere tidspunkt. ${ }^{352}$ Det fremstår her som om sivilombudsmannen legger til grunn at betalerens sviktende rutiner innebærer at han selv bør bære risikoen for mottagerens innrettelse og tap av berikelse. I to av de nevnte sakene ble resultatet at sivilombudsmannen rettet kritikk mot kommunen. I saken fra 2009 ble utfallet det motsatte, og dette skyldtes uaktsomhet fra mottagers side. Det virker som at man her har foretatt en avveining av betalers og mottagers uaktsomhet og landet på at mottager var mer å bebreide enn betaleren.

Også folketrygdloven $\S 22-15$ bygger på en tanke om skylddeling. Der mottager har vært i aktsom god tro, er han som nevnt beskyttet mot å lide tap. Der mottager har vært i positiv ond tro skal derimot pengene alltid tilbakebetales. Men dersom «feilen helt eller delvis kan tilskrives Arbeids- og velferdsetaten, Helsedirektoratet eller organ underlagt Helsedirektoratet», kan dette utgjøre en særlig grunn som tilsier at krav likevel ikke skal fremmes eller bør settes ned, selv om også mottager har vart uaktsom. ${ }^{353}$ Regelen var ment som en lovfesting og utvidelse av tidligere trygderettspraksis, hvoretter tilbakesøkningskravet ble halvert der betaleren var å laste for feilbetalingen. ${ }^{354}$ Regelen innebærer en skylddeling der både mottager og betaler har vært uaktsomme.

Etter folketrygdloven $\S 22-15$ fjerde ledd kan det virke som at der betaler har betydelig skyld i feilutbetalingen, skal dette tillegges vekt uavhengig av om mottager har innrettet seg. Hverken i loven eller i forarbeidene er det vist til innrettelse som en forutsetning for nektelse etter fjerde ledd. Femte ledd fremhever derimot innrettelse som et relevant moment der mottager har vært i aktsom god tro. Det synes derfor merkelig dersom nektelse skulle være aktuelt for en uaktsom mottager som ikke har innrettet seg. Mer nærliggende er å tenke at man ved ytelser

\footnotetext{
${ }^{351}$ Rt. 1998 s. 989 (side 1000).

${ }^{352}$ SOM-2009-2194, SOM-2015-1834 og SOM-2017-256.

353 Jf. folketrygdloven $\S 22-15$ fjerde ledd.

${ }^{354}$ Se Ot.prp. nr. 76 (2007-2008) side 84. Se også Kjønstad (2011) side 154.
} 
til livsopphold nærmest legger til grunn innrettelse. ${ }^{355}$ I litteraturen viser Kjønstad til at «innrettelse i tillit til betalingen» må anses som et supplerende moment ved vurderingen etter fjerde ledd. ${ }^{356}$

Ved vurderingen av om betaleren er å bebreide, vil kjente momenter som betalingspress og påvirkning fra mottager eller tredjemann kunne sorteres. Der uaktsomhet hos betaleren ikke var den avgjørende grunnen til feilbetalingen, bør eventuelle bebreidelser tillegges liten betydning.

På bakgrunn av det som er sagt ovenfor kan vi slutte at det først er der en uaktsom mottager har innrettet seg at betalerens (u)aktsomhet får betydning. Dersom betaleren i disse tilfeller har vært aktsom, vil det trekke i retning av full tilbakebetaling. Har derimot også betaleren vært uaktsom kan det være aktuelt med en skylddeling. Der mottageren overhodet ikke har innrettet seg, har han imidlertid intet beskyttelsesbehov, og tilbakes $\varnothing$ kning bør skje uavhengig av betalerens aktsomhet.

\subsubsection{Sammenfatning av vurderingstema}

På bakgrunn av de tre ovennevnte momentene, kan man skissere en følgende fremgangsmåte for helhetsvurderingen av om tilbakesøkning likevel helt eller delvis må nektes. Vi må først etablere om mottager har vært i positiv ond tro. Er dette tilfellet, bør tilbakesøkning uansett skje. Er mottager ikke i positiv ond tro, kan vi gå videre til å vurdere innrettelse. Innrettelse bør være et vilkår for å nekte tilbakesøkning. Der mottager ikke har innrettet seg, bør pengene uansett tilbakeføres. I disse tilfellene har ikke mottager noe beskyttelsesbehov, og en eventuell nektelse ville utelukkende vært en sanksjonering av betaleren. Av samme grunn bør en mottager som kun delvis har innrettet seg, tilbakeføre den delen av berikelsen som er i behold der dette er mulig å påvise.

Hvorvidt tilbakesøkning helt eller delvis skal nektes der mottager har innrettet seg, må deretter bero på en helhetsvurdering på bakgrunn av mottagers og betalers (u)aktsomhet. Der mottager har innrettet seg i aktsom god tro, bør tilbakesøkning utover den bevarte berikelsen nektes. Har mottager derimot vært uaktsom, men ikke i positiv ond tro, må det foretas en nærmere vurdering. Her må det foretas en relativ aktsomhetsvurdering, altså en avveining av hvem av partene som er mest å bebreide, eller som var nærmest til å avdekke feilen. Dersom betaleren overhodet ikke er å bebreide, bør den uaktsomme mottageren tilbakeføre hele beløpet. Tilsvarende bør være tilfellet der betaler er betydelig mindre å bebreide enn mottager. Er der-

\footnotetext{
355 NOU 1990: 20 side 698.

${ }^{356}$ Kjønstad (2011) side 144.
} 
imot begge parter å bebreide, er det nærliggende å foreta en skylddeling, slik at tapet fordeles mellom betaler og mottager, uavhengig av om berikelsen er i behold.

Uavhengig av mottagers godtroende innrettelse, synes det å følge av dommene om betaling fremkalt ved tredjemanns svik, at det i disse tilfellene må foretas en konkret vurdering. ${ }^{357}$ Her synes utgangspunktet å være at betaler må ha hele tilbakesøkningskravet i behold, så fremt han selv ikke er å bebreide. I disse dommene er imidlertid ikke innrettelse særskilt vurdert. Har en godtroende mottager innrettet seg i disse tilfellene, kan man derfor stille spørsmål om man bør opprettholde dette utgangspunktet. ${ }^{358}$ Der man ikke foretar identifikasjon mellom mottager og tredjemann, synes det lite rimelig at aktsomt godtroende mottager her bestandig skal måtte tilbakebetale det fulle beløp, med risiko for å lide tap.

\subsection{Oppsummering}

Det første jeg tok stilling til, var om man også i norsk rett kan bygge på en hovedregel om tilbakesøkning. Formelt sett opererer man ikke med en hovedregel i norsk rett. Men resultatene i saker om tilbakesøkning, samt enkelte uttalelser fra Høyesterett, tilsier at man kan oppstille en slik regel. En slik regel finner man igjen både fra spesiallovgivningen og fra fremmed rett. At en slik regel vil forenkle vurderingstemaet ved tilbakesøkning, tilsier at den $b \phi r$ oppstilles.

I tillegg til å konstatere at en hovedregel om tilbakes $\varnothing \mathrm{kning}$ vil være forenelig med norsk rett, har jeg vurdert om det er mulig å presisere vurderingstema for når tilbakesøkning bør nektes innenfor rammen av helhetsvurderingen. $\mathrm{Vi}$ så at innrettelse og mottagers og betalers (u)aktsomhet er relevante momenter ved helhetsvurdering. Disse momentene kan struktureres i en unntaksregel, slik som vist i punkt 7.4.5. En slik tilnærming til helhetsvurderingen vil gi domstolene et klarere vurderingstema og partene et klarere bevistema. Der det er mulig å påvise at deler av berikelsen er i behold hos mottager, bør tilbakes $\varnothing$ kning for denne delen skje uavhengig av mottagers aktsomhet.

En tilnærming som skissert ovenfor vil følge samme hovedlinjer som i svensk rett, og også ligge tett opp om reguleringen i folketrygdloven $\S 22-15$. Tilnærmingen kan legges til grunn innenfor rammen av den helhetsvurderingen som man i dag opererer med. Tilnærmingen tar sikte på å ivareta generelle rimelighetshensyn, både hensynet til godtroende mottager og hensynet til betaler som har betalt noe han ikke skyldte, samtidig som at disse hensynene balanseres med hensynet til forutberegnelighet.

\footnotetext{
${ }^{357}$ Rt. 2001 s. 1580 , Rt. 1995 s. 1641 og Rt. 1985 s. 290.

${ }^{358}$ Se lignende betraktninger hos Lindskog (2018) side 835.
} 


\section{Konklusjon}

I kapittel 4 til 6 har jeg på bakgrunn av en analyse av Høyesteretts praksis forsøkt å kartlegge innholdet i gjeldende rett om tilbakesøkning ved feilbetaling. I dette ligger ikke bare en deskriptiv analyse av hvordan Høyesterett faktisk har gått frem i tidligere saker, men også en vurdering av hvordan man $b \phi r$ argumentere på bakgrunn av de kildene man har om spørsmål knyttet til ulovfestet tilbakesøkning. Et visst normativt tilsnitt finner man derfor i alle kapitlene, og dette kommer man ikke utenom når man ser på en rettslig standard hvor Høyesteretts skjønn i liten grad er begrenset.

I kapittel 4 utledet jeg to grunnvilkår for tilbakes $\varnothing$ kning: Det må ha skjedd en formuesoverføring, og denne må ha savnet rettsgrunn. Fravær av rettsgrunn innebærer at det ikke må ha foreligget foregående forpliktelse for betalingen, og at betalingen heller ikke må utgjøre en selvstendig rettslig disposisjon. Dersom disse to grunnvilkårene $i k k e$ er oppfylt, er det $i k k e$ aktuelt med tilbakesøkning. Allerede ved å sette navn på disse grunnvilkårene har man bidratt til å klargjøre spørsmålet om tilbakesøkning. Der uenigheten knytter seg til hvorvidt betalingen utgjorde en selvstendig forpliktelse, er dette et spørsmål om ulovfestede regler om tilbakes $\varnothing \mathrm{k}$ ning kommer til anvendelse, og ikke et spørsmål for helhetsvurderingen. Disse to vurderingene må holdes adskilt for å gi et klarest mulig vurderingstema.

Dersom grunnvilkårene er oppfylt, kan det være aktuelt med tilbakesøkning. Den uttalte hovedregelen der grunnvilkårene er oppfylt, er at man ikke har noen hovedregel, og at hvert tilfelle må vurderes konkret. I kapittel 5 så vi imidlertid at det i enkelte tilfeller vil foreligge en hovedregel om tilbakesøkning. Dette gjelder tilfeller hvor det er innbetalt avgift uten at det forelå tilstrekkelig lovhjemmel, og tilfeller hvor mottager har vært i positiv ond tro ved mottagelsen av betalingen.

I de $\varnothing$ vrige tilfellene er den uttalte hovedregelen at det skal foretas en helhetsvurdering. I kapittel 6 har jeg sett på enkelte momenter som er trukket frem i Høyesteretts begrunnelser, og som vil kunne ha relevans ved helhetsvurderingen. Hvordan den innbyrdes vektingen av disse momentene skal gjøres, sier ikke Høyesterett noe eksplisitt om. Begrenser man seg til Høyesteretts uttalte begrunnelse, må hovedregelen fortsatt være at domstolene står fritt til å foreta en konkret vurdering av hvilket resultat de finner mest rimelig i det enkelte tilfellet. Den høyesterettspraksis som foreligger, gir begrenset veiledning til hvordan vektingen av ulike momenter skal gjøres, og oppstiller ingen klare regler om hva domstolene kan eller skal legge vekt på i den enkelte sak.

I kapittel 7 så vi imidlertid at det kan oppstilles et klarere vurderingstema for helhetsvurderingen. Den tilnærmingen som presenteres i kapittel 7, pretenderer ikke å gi uttrykk for hvor- 
dan domstolene må vurdere spørsmål om tilbakesøkning, men den gir uttrykk for hvordan domstolene, innenfor rammen av norsk rett, kan strukturere helhetsvurderingen på en måte som gir et klarere vurderingstema både for parter og rettsanvendere. I henhold til dette vurderingstemaet er utgangspunktet at det ved feilbetalinger skal skje en tilbakebetaling. Ved vurderingen av om tilbakebetaling likevel skal nektes, er det vilkår om at mottager ikke har vært i positiv ond tro, og at han har innrettet seg. Deretter må vi vurdere henholdsvis mottagers og betalers aktsomhet. 


\section{Avsluttende normative betraktninger}

I kapittel 8 har jeg sett på hvordan man kan presisere vurderingstemaet for helhetsvurderingen. Som vist ovenfor, mener jeg at en slik tilnærming vil bidra til å styrke forutberegneligheten, samtidig som at man ivaretar hensynet til godtroende mottager. Samtidig er forrige kapittel skrevet med et $\varnothing$ nske om å presentere en tilnærming som holder seg innenfor rammen av gjeldende rett. Dette har derfor satt grenser for hvor fritt jeg kunne stille meg.

I norsk rett har det gjennom tidene vært en stor skepsis mot generelle regler om tilbakesøkning av feilbetalinger. Ørsted gikk allerede i 1828 hardt ut mot en generell regel om tilbakesøkning, som etter hans mening ville medføre «de største og meest $\varnothing$ delæggende Ubilligheder, ja der vilde opstaae en Rettighedernes rolige Nydelse aldeles forstyrrende Usikkerhed i det borgerlige Liv». ${ }^{359}$ Ørsted viste til den romerske lære om at ingen skulle berikes uberettiget på andres bekostning. Men at denne skulle kunne utgjøre et reelt fundament for tilbakesøkningsplikten, stilte han seg avvisende til. ${ }^{360}$ I en slik lære kunne ikke ligge mer enn at det var «mod naturlig Billighed, at Nogen beholder Det, som uden gyldig Retsgrund (sine causa) findes hos ham». ${ }^{361} \mathrm{Da} \emptyset$ rsted bygget på at man i alminnelighet måtte kunne utlede en erkjennelse fra betalingen, ville imidlertid ikke betalingen være uten rettsgrunn, og derfor måtte også tilbakesøkning i alminnelighet nektes. ${ }^{362}$ Riktignok innrømmet Ørsted at det i enkelte tilfeller kunne være på sin plass med tilbakesøkning, men det måtte være i særlige typetilfeller. ${ }^{363}$ Denne fremgangsmåte, der man vurderte enkelte tilfeller hvor tilbakesøkning kunne være på sin

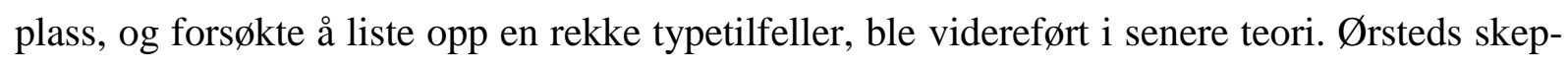
sis til tilbakesøkning lot seg begrunne for det første i at betalingen måtte anses som en erkjennelse, og for det annet $i$ at mottagerne måtte kunne innrette seg i tillit til betalingen. Dette siste hensynet kom til å begrunne nektelse av tilbakesøkning, fremfor å begrunne at tilbakesøkning måtte innrømmes, men begrenses til bevart berikelse. Også Ørsteds tanker om erkjennelse fikk prege skandinavisk teori, og da særlig Arnholms og Ussings teorier. ${ }^{364}$

Blant dem som stillet seg mindre fiendtlig til tilbakesøkning, ble en rekke forskjellige grunnlag for en rett til tilbakes $\varnothing$ kning anført. I dansk rett anså Lassen tilbakes $\varnothing$ kningsretten begrunnet i forutsetningslæren, og tanken om et stilltiende forbehold om tilbakesøkning dersom beta-

\footnotetext{
${ }^{359}$ Ørsted (1930) side 276.

${ }^{360}$ Ibid. side $275-276$.

${ }^{361}$ Ibid.

${ }^{362}$ Ibid. side 276.

363 Ibid. side $280 \mathrm{flg}$.

${ }^{364}$ Arnholm (1939) side 168 flg. og Ussing (1946) side 432 flg.
} 
lingsforpliktelse ikke forelå. ${ }^{365}$ I norsk rett var Gjelsvik og Stang representanter for lignende syn. ${ }^{366}$ Hagerup begrunnet derimot condictio indebiti i «ugrundet Berigelse», men han forklarte berikelsens ugrunnethet med at forutsetningsbristen «betar denne dens Evne til å være fyldestgjørende Retsgrund for den derved bevirkede Formuesforrykkelse. Afhænderen har vistnok villet Afhændelsen, men ikke Berigelsen.» ${ }^{367}$ Arnholm på sin side begrunnet tilbakesøkning, der denne unntaksvis måtte innrømmes, $i$ at oppfyllelseshandlingene ble ugyldige. ${ }^{368}$

At man stort sett ikke har villet bygge på et alminnelig utgangspunkt om at den som har mottatt en uberettiget berikelse, skal tilbakeføre denne, har nok preget den skandinaviske modellen. Og at Ørsted avviste berikelseslæren som urimelig, uten å vurdere begrensningen til bevart berikelse, var nok grunnlag for mye av den skepsis man har hatt til en slik lære i skandinavisk rett. Uten denne begrunnelsen, som ligger til grunn i både kontinentaleuropeisk og nå også engelsk rett, blir man nødt til å konstruere begrunnelser for tilbakesøkning i den enkelte sak.

De uroligheter som man i skandinavisk rett var så redde for, kunne vært unngått om man hadde hentet et mer helhetlig tankegods fra Europa. En unntaksfri regel om tilbakesøkning ville vitterlig vært urimelig. Men det ville også «pacta sunt servanda» vært uten ugyldighetslæren. Og like lite som man kan tenke seg «pacta sunt servanda» uten ugyldighetslæren, bør man kunne tenke seg condictio indebiti uten en begrensning til bevart berikelse.

Skal man hente inspirasjon fra fremmed rett, må man se retten i sammenheng. Man kan ikke vurdere en hovedregels godhet uten å ha vurdert unntak og begrensninger. Slik er det også med tilbakesøkning. En hovedregel om tilbakesøkning ivaretar et grunnleggende hensyn til at den som har fått noe han ikke har krav på, skal gi det tilbake, og at den som har betalt noe han ikke skyldte, skal få det tilbake. En begrensning til bevart berikelse ivaretar hensynet til godtroende mottager. Hensynet til betaleren der mottager er i ond tro, er også ivaretatt ved berikelsesgrunnsetningen: Den som mottar i ond tro, kan ikke gjøre gjeldende at tilbakes $\emptyset$ kningskravet er begrenset til eksisterende berikelse. En slik tilnærming setter rimelighetsvurderingen inn i system og gjør helhetsvurderingen overflødig.

Dette tankegods var kjent i europeisk lovgivning, teori og praksis allerede for mer enn hundre år siden. ${ }^{369}$ Man kan derfor stille seg spørsmål om hvorfor man ikke tidligere har gått denne

\footnotetext{
${ }^{365}$ Lassen (1897) side 875 flg.

${ }^{366}$ Gjelsvik (1897) side 64-74 og Stang (1897) side 81 flg.

${ }^{367}$ Hagerup (1885) side 252.

${ }^{368}$ Arnholm (1939) side 234-235.

369 Jitta (1907) side 407-431.
} 
veien dersom den skulle ha så mange flere kvaliteter enn den vi selv har tatt. Svaret på dette tror jeg ligger i rettsvitenskapens tendens til å legge sten på sten og bygge videre innenfor rammen av det eksisterende. Dette kan være en kvalitet, men det kan også låse oss til en uheldig kurs.

Den tilnærmingen vi i dag har til spørsmål om tilbakesøkning, reflekterer en manglende vilje fra Høyesterett til å utvikle generelle retningslinjer for vurderingstemaet. I strid med Høyesteretts ambisjon om å bidra til rettsavklaring, har de på tilbakesøkningens område bidratt til det motsatte. Det er illustrerende at uttalelser fra Rt. 1985 s. 290, om at hovedregelen er at det ikke finnes noen regel, og fra Rt. 2001 s. 1580, om at det heller ikke finnes noe klart anvendelsesområde, blir gjentatt av Høyesterett som de sentrale kjennetegn ved gjeldende rett. For å komme oss videre i utviklingen må enten Høyesterett eller lovgiver komme mer aktivt på banen. At domstolen kan spille en avgjørende rolle for å klargjøre vurderingstemaet, har vi et eksempel på fra svensk rett. Her har Högsta domstolen gått aktivt frem for å klargjøre vurderingstemaet for spørsmålet om tilbakesøkning. En tilsvarende tilnærming bør kunne foretas av Høyesterett innenfor rammen av norsk rett, og en slik tilnærming er skissert i kapittel 7.

Samtidig er heller ikke den svenske fremgangsmåten, etter mitt syn, udelt heldig. Særlig at man i senere praksis har åpnet døren for en helhetsvurdering som et tredje ledd i vurderingen, etter at man har tatt stilling til mottagers gode tro og innrettelse, er etter mitt syn egnet til å gjøre vurderingstemaet mindre oversiktlig. Dersom lovgiver skulle komme på banen, mener jeg derfor at man særlig bør se til utenlandsk rett hvor man bygger på en berikelseslære, med en begrensning til bevart berikelse. En slik løsning for feilbetalingstilfellene behøver imidlertid ikke forutsette en generell berikelseslare.

For det første må man ha et klart anvendelsesområde for tilbakesøkning. Dette bør defineres slik at der det er betalt uten foregående forpliktelse, og betalingen heller ikke utgjør en rettslig disposisjon, har betaleren krav på tilbakesøkning. Fra dette utgangspunktet kan det gjøres konkrete unntak, for eksempel for betaling av foreldet gjeld, eller andre typer ikke-rettslige forpliktelser, som man fortsatt mener bør binde selv om de ikke kunne vært krevet rettslig oppfyllelse for før betalingen.

Når man har definert tilbakesøkning og oppstilt en hovedregel, blir spørsmålet om det må gjøres unntak utover unntak fra regelens anvendelsesområde. Slike ytterligere unntak bør ikke være nødvendig. ${ }^{370}$ Forutsetningen for en absolutt regel er imidlertid at man opererer med en

\footnotetext{
${ }^{370}$ At det kan være behov for avvikende reguleringer på enkelte rettsområder hvor andre hensyn spiller inn, for eksempel hvor det er $\emptyset$ nskelig å sanksjonere mot uaktsomme betalere, er en annen sak. Det vi her snakker om er den alminnelige regelen.
} 
begrensning av tilbakesøkningssummen til den bevarte berikelsen. Hvis man anser retten til tilbakesøkning bygget på det grunnlag at mottager ikke skal få en uberettiget berikelse, er det ingen grunner til å la tilbakesøkningsbeløpet overstige den berikelsen som er i behold, forutsatt at den var mottatt og brukt i god tro. I motsetning til ved skadeserstatning eller erstatning for kontraktsbrudd skyldes ikke kravet mottagers skyld, men simpelthen at betalingen ikke hadde rettsgrunn. Dermed lar det seg ikke begrunne at mottager skal være ansvarlig utover den bevarte berikelsen. Heller ikke lar det seg begrunne at man skal nekte kravet om tilbakesøkning i sin helhet på grunn av delvis innrettelse eller betalers uaktsomhet. Mottager skal være beskyttet mot å lide netto tap, men utover dette er det ikke noen grunn til å beskytte mottagers interesse av en uberettiget berikelse. En svensk modell hvor man opererer med enten fullstendig tilbakesøkning eller fullstendig nektelse, lar seg derfor ikke forsvare. Heller ikke prosessøkonomiske hensyn kan fullt ut rettferdiggjøre en «enten eller»-regel. Rett nok vil man risikere tvister om hvorvidt berikelsen er i behold eller ei, men dette er en bevismessig vurdering som domstolene er egnet til å håndtere, og som det må forutsettes at også partene vil ta $\mathrm{i}$ betraktning når de vurderer prosessrisikoen.

For vurderingen av hvorvidt berikelsen er i behold, kan man ikke nøye seg med å se om mottager fortsatt har pengene i behold, men man må finne ut om vedkommende ved full tilbakesøkning ville stått igjen med et netto tap på grunn av disposisjoner foretatt $i$ tillit til betalingen, og som ikke ellers ville vart gjort. Her vil domstolene kunne trekke retningslinjer for vurderingen, og mange av de momenter vi kjenner fra vår hjemlige helhetsvurdering, kan sorteres under denne vurderingen, men da som bevismomenter, hvis vekt er avhengig av at de kaster lys over den bevarte berikelsen: Tidsmomentet, fordringens art og innrettelse kan tilsi at berikelsen er forbrukt, mens subjektive forhold, betalingssituasjonen, betalingens størrelse og forbehold kan være egnet til å frarøve mottager hans gode tro.

Der mottager mottar eller forbruker beløpet i ond tro, bør hele beløpet tilbakebetales. Men dette kan begrunnes nettopp i en sanksjonering av mottagers onde tro. Det har dermed en side til erstatningsretten og står ikke i strid med en generell begrensning til bestående berikelse. I den grad det skal gjøres ytterligere unntak fra berikelsesbegrensningen bør disse angis positivt, slik at man ikke ender tilbake i en helhetsvurdering. For eksempel kan det være at berikelsesbegrensningen ikke bør komme til anvendelse der pengene er forbrukt ved kriminell virksomhet, eller der en begrensning til bevart berikelse av andre grunner ville stride mot hensynene bak offentligrettslige regler. ${ }^{371}$

\footnotetext{
${ }^{371}$ Se til sammenligning Burrows (2012) side 120-122 og Birks (2005) side 218.
} 
Simpel uaktsomhet fra mottager bør ikke føre til at mottager går i tap på grunn av en feilbetaling. Samtidig må grensen trekkes mot de tilfeller der mottager har unngått å undersøke om han hadde rett på beløpet, der omstendighetene tilsa at han burde fattet mistanke. Men denne «burde»-vurderingen må ikke gå så langt at mottagere som ikke har full oversikt over penger som går inn på konto eller alle postene på en lønnsslipp, blir ansett å være i ond tro; gjør den det, blir det risikosport å stole på en mottatt betaling, og Ørsted ville få rett i sin dystre spådom. Man bør altså holde ond tro-unntaket fra berikelsesbegrensningen innenfor snevre rammer. Den tilnærmingen som er gjort i engelsk rett, er derfor egnet til forbilde. Et snevert unntak fra berikelsesbegrensningen er avgjørende for å kunne ha en absolutt hovedregel om tilbakesøkning uavhengig av betalers uaktsomhet. Som Birks skriver: «If even the careless defendant were disqualified from the defence the risk of loss would to that extent lie on him, which would seem monstrous if the rule were maintained, even after disenrichment, that the claimant's own negligence was irrelevant.»» ${ }^{372}$

Regler om tilbakesøkning basert på en berikelseslære, som skissert ovenfor, vil også by på utfordringer og vanskelige grensedragninger. Dette ser man fra fremstillinger av engelsk rett på temaet. Men utgangspunktene er klare og gir grunnlag for forutberegnelighet. De ivaretar også de grunnleggende rimelighetshensynene vi har prøvd å fange i helhetsvurderingen: Betaleren bør få tilbake det han har betalt uten å skylde det, men godtroende mottager bør ikke stilles dårligere enn dersom betalingen aldri hadde funnet sted.

\footnotetext{
372 Birks (2005) side 219.
} 


\section{Kilderegister}

\section{Norske lover}

1687

Lov 15. april 1687 Kong Christian Den Femtis Norske Lov (Norske Lov)

1902

1918

Lov 22. mai 1902 nr. 10 Almindelig borgerlig Straffelov (straffeloven) [opphevet]

ugyldige viljeserklæringer (avtaleloven)

1952

1966

Lov 21. november $1952 \mathrm{nr}$. 2 om betaling og innkreving av skatt (skattebetalingsloven) [opphevet]

1978

Lov 17. juni $1966 \mathrm{nr} .12 \mathrm{om}$ folketrygd [opphevet]

1979

Lov 2. juni 1978 nr. 37 om godtroerverv av løsøre (godtroervervloven)

1981

Lov 18. mai $1979 \mathrm{nr} .18$ om foreldelse av fordringer (foreldelsesloven)

1989

Lov 8. april $1981 \mathrm{nr} .7 \mathrm{om}$ barn og foreldre (barnelova)

1992

Lov 16. juni $1989 \mathrm{nr} .69$ om forsikringsavtaler (forsikringsavtaleloven)

1997

Lov 27. november $1992 \mathrm{nr} .117$ om offentlig støtte

1999

Lov 28. februar $1997 \mathrm{nr} .19$ om folketrygd (folketrygdloven)

ven)

2005 Lov 20. mai 2005 nr. 28 om straff (straffeloven)

2005 Lov 17. juni 2005 nr. 67 om betaling og innkreving av skatte- og avgiftskrav (skattebetalingsloven)

2010 Lov 26. mars 2010 nr. 9 om vergemål (vergemålsloven)

$2015 \quad$ Lov 12. mai $2015 \mathrm{nr} .27 \mathrm{om}$ forsvunne personar

\section{Norske forarbeider}

Ot.prp. nr. 56 (1976-1977) Om lov om godtroerverv av løsøre

Ot.prp. nr. 38 (1977-1978) Om lov om forelding av fordringer

NOU 1990: 20

Forenklet folketrygdlov

Ot.prp. nr. 50 (1993-1994) Om lov om endringer i lov 4 februar 1977 nr 4 om arbeidervern og arbeidsmiljø m.v

Ot.prp. nr. 76 (2007-2008) Om lov om endringar i folketrygdlova og i enkelte andre lover (tilbakekrevjing etter feilutbetalingar, tiltak mot trygdemisbruk, renter og erstatning i trygdesaker)

Ot.prp. nr. 110 (2008-2009) Om lov om vergemål (vergemålsloven)

Ot.prp. nr. 22 (2008-2009) Om lov om endringer i straffeloven 20. mai 2005 nr. 28 (siste delproposisjon - sluttføring av spesiell del og tilpasning av annen lovgivning) 


\section{Norsk rettspraksis}
Rt. 1836 s. 627
Rt. 2004 s. 782
Rt. 1927 s. 237
Rt. 2006 s. 1265
Rt. 1927 s. 1052
Rt. 2006 s. 1281
Rt. 1930 s. 764
Rt. 2008 s. 738
Rt. 1933 s. 323
Rt. 2008 s. 1510
Rt. 1934 s. 33
Rt. 2008 s. 1582
Rt. 1934 s. 400
Rt. 2010 s. 816
Rt. 1953 s. 1460
Rt. 2010 s. 1500
Rt. 1959 s. 1129
Rt. 2012 s. 722
Rt. 1976 s. 579
Rt. 2012 s. 1444
Rt. 1979 s. 69
Rt. 2012 s. 1904
Rt. 1985 s. 290
Rt. 2013 s. 1665
Rt. 1988 s. 556
HR-2016-2491-A
Rt. 1995 s. 1641
HR-2017-971-A
Rt. 1997 s. 1029
HR- 2017-2414-A
Rt. 1997 s. 1210
LB-1999-414
Rt. 1998 s. 989
LH-2010-81939
Rt. 2001 s. 1580
LB-2005-117741
Rt. 2003 s. 172
Rt. 2003 s. 1243

Annen offentlig praksis

SOMB-1997-68

SOM-2015-1834

SOM-2009-2194

SOM-2017-256

\section{Litteratur}

Arnholm (1939)

Arnholm, Carl Jacob. Streiftog i obligasjonsretten, Oslo: Tanum, 1939.

Arnholm (1966) Arnholm, Carl Jacob. Privatrett III: Almindelig obligasjonsrett, Oslo: Tanum, 1966.

Arnholm (1974) Arnholm, Carl Jacob. Privatrett III: Almindelig obligasjonsrett, 2. utg., Oslo: Tanum, 1974.

Augdahl (1972) ～Augdahl, Per. Den norske obligasjonsretts almindelige del, 4. utg., Oslo: Aschehoug, 1972

Augdahl (1978) ～Augdahl, Per. Den norske obligasjonsretts almindelige del, 5. utg., Oslo: Aschehoug, 1978.

Bénabent (2017) Bénabent, Alain. Droit des obligations, 16. utg., Issy-lesMoulineaux: LGDJ, 2017. 
Bergsåker (2015)

Birks (2005)

Burrows (2012)

Eckhoff (2001)

Falkanger (2016)

Gjelsvik (1897)

Hagerup (1885)

Hagstrøm (2011)

Hauge (2009)

Hult (1947)

Huser (1983)

Ingvarsson (2016)

Jitta (1907)

Kjønstad (1983)

Kjønstad (1983)

Kjørven (2011)
Bergsåker, Trygve. Pengekravsrett, 3. utg., Oslo: Gyldendal Akademisk, 2015.

Birks, Peter. Unjust enrichment, 2. utg., Oxford: Oxford University Press, 2005.

Burrows, Andrew. A restatement of the English law of unjust enrichment, Oxford: Oxford University Press, 2012.

Eckhoff, Torstein. Rettskildelare, 5. utg. [redigert av] Jan E. Helgesen, Oslo: Universitetsforlaget, 2001.

Falkanger, Thor og Hans Jacob Bull. Sjørett, 8. utg., Oslo: Sjørettsfondet akademisk, 2016.

Gjelsvik, Nikolaus. Den norske privatrets lare om vildfarelsens indflydelse paa retshandlers gyldighed, Kristiania: Fabritius, 1897.

Hagerup, Francis. «Om Principperne for condictio indebiti», i Norsk Retstidende: Ugeblad for Lovkyndighed, Statistik og Statsфkonomi, Den norske Sagførerforening (red.), Kristiania: Tangen, Abelsted's Efterf., 1885.

Hagstrøm, Viggo. Obligasjonsrett, 2. utg., Oslo: Universitetsforlaget, 2011.

Hauge, Hilde. Ugyldighet ved formuerettslige disposisjoner: analyser av begrepsbruk, strukturer og argumentasjonslinjer i den avtalerettslige ugyldighetslare, Oslo: Universitetsforlaget, 2009.

Hult, Phillips. «Condictio indebiti», i Festskrift tillägnad Vilhelm Lundstedt, Uppsala: Lundequistska bokhandeln, 1947, s. 230-270. Huser, Kristian. Avtaletolking: en innføring i avtaletolkingslaerens alminnelige del, Bergen: Universitetsforlaget, 1983.

Ingvarsson, Torbjörn. «Condictio indebiti», Fordringsrättsliga studier 01, Taberg: Eget forlag, 2016.

Jitta, Daniel Josephus. La substance des obligations dans le droit international privé: Tombe Second: Obligations qui n'ont pas leur source dans un contrat: conclusions, La Haye: Librairie Belinfante frères, 1907.

Kjønstad, Asbjørn og Steinar Tjomsland. Foreldelsesloven, Oslo: Universitetsforlaget, 1983.

Kjønstad, Asbjørn. «Motregning og tilbakebetaling av pengekrav, i obligasjonsretten og i trygderetten», Jussens Venner nr. 3 (2011) s. 131-164

Kjørven, Marte Eidsand, Herman Bruserud og Håvard H. Holdø m.fl. Foreldelse av fordringer, Oslo: Universitetsforlaget, 2011. 
Knoph (1939)

Krüger (1984)

Lassen (1897)

Lilleholt (2003)

Lilleholt (2017)

Lilleholt (2018)

Lindskog (2018)

Malaurie (2016)

Monsen (2005)

Stang (1897)

Tercier (2009)

Terré (2005)

Tørum (2002)

Ussing (1946)

Vinding Kruse (1950)

Virgo (2015)

Woxholth (2017)
Knoph, Ragnar. Rettslige standarder: sarlig Grunnlovens §97, Oslo: Grøndahl \& Søns Boktrykkeri, 1939.

Krüger, Kai. Pengekrav, 2. utg., Bergen: Universitetsforlaget, 1984. Lassen, Jul. Haandbog i obligationsretten: Speciel del, Kjøbenhavn: G.E.C. Gads Forlag, 1897.

Lilleholt, Kåre. «Når rettskjeldene bryt med Systemet i privatretten» (2003), hentet fra

<http://folk.uio.no/kaareli/Publisering/Systemet.htm>

Lilleholt, Kåre. Kontraktsrett og obligasjonsrett, Oslo: Cappelen

Damm Akademisk, 2017.

Lilleholt, Kåre. Allmenn formuerett: Fleire rettar til same formuesgode, 2. utg., Oslo: Universitetsforlaget, 2018.

Lindskog, Stefan. Betalning: om kongruent infriande av penningskulder och andra betalningsrättsliga frågor, 2. utg. Stockholm: Norstedts Juridik AB, 2018.

Malaurie, Philippe, Laurent Aynès og Philippe Stoffel-Munck. Droit des obligations, 8 utg. Issy-les-Moulineaux: LGDJ, 2016.

Monsen, Erik. «Om restitusjonskrav på ulovfestet grunnlag», Jussens Venner nr. 3 (2005), s. 157-197.

Stang, Fredrik. Om Vildfarelse og dens Indflytelse efter norsk Privatret på en Retshandels Gyldighed, Kristiania: A.W. Brøggers Bogtrykkeri, 1897.

Tercier, Pierre. Le droit des obligations, 4. utg., Zurich: Schultess, 2009.

Terré, François, Philippe Simler og Yves Lequette. Droit civil : les obligations, 9. utg., Paris: Dalloz, 2005.

Tørum, Amund Bjøranger. «Konsekvens i formueretten», Jussens Venner nr. 4-5 (2002), s. 314-339.

Ussing, Henry. Dansk obligationsret: speciel del: II: Enkelte kontrakter, 2. utg, København: G.E.C Gads Forlag, 1946.

Vinding Kruse, Anders. Restitutioner: et bidrag til unders $\phi g e l s e n$ af berigelsesgrundsatningen i dansk og fremmed ret, København: G.E.C Gads Forlag, 1950.

Virgo, G.J. «Restitution», i Chitty on contracts: Volume 1: General principles, H.G. Beale (red.), 32. utg., London: Sweet \& Maxwell, 2015, s. 2091-2243.

Woxholth, Geir. Avtalerett, 10. utg., Oslo: Gyldendal akademisk, 2012. 
Zimmermann (1990) Zimmermann, Reinhard. The law of obligations: Roman foundations of the civilian tradition, Cape Town: Juta, 1990.

Ørsted (1930) Ørsted, Anders Sandøe. «Om tilbagesøgelse af uretteligen erlagte betalinger» [først publisert i Juridisk Tidsskrift, 14 Bd. 2 H. (1828)], i Privatretlige skrifter i udvalg anden afdeling, København: Gyldendalske boghandel, 1930.

\section{Utenlandske lover}

1804 Code civil des Français (Code civil), som oppdatert 3. januar 2018, Frankrike. 1900 Bürgerliches Gesetzbuch (BGB), som oppdatert 1. oktober 2013 (offisiell engelsk oversettelse), Tyskland.

1911 Loi fédérale complétant le Code civil suisse (Code des obligations), som oppdatert 1. april 2017, Sveits.

\section{Utenlandsk rettspraksis}

Engelsk rett:

Kelly v Solari

Lipkin Gorman v Karpnale

Woolwich v Inland Revenue

Kleinworth v Lincoln City

Dextra Bank v Bank of Jamaica

Test Claimants FII Group Litigation v Revenue and Customs

Harrison v Madejski
Kelly v Solari, [1841] 9 M \& W 54

Lipkin Gorman v Karpnale Ltd, [1991] 2 A.C. 548

Woolwich Equitable Building Society Respondents v Inland Revenue Commissioners Appellants, [1993] A.C. 70 Kleinwort Benson Ltd v Lincoln City Council, [1999] 2 A.C. 349

Dextra Bank \& Trust Co Ltd v Bank of Jamaica, [2002] 1 All E.R. (Comm) 193

Test Claimants in the FII Group Litigation v Revenue and Customs Commissioners, [2012] UKSC 19 Harrison v Madejski and Coys of Kensington, [2014] EWCA Civ 361

Svensk rett:

NJA 1994 s 177

NJA 2011 s. 739

NJA 2001 s. 353

NJA 2015 s. 1072

NJA 2005 s. 142

\section{Andre kilder}

Bokmålsordboka, Landrø, Marit Ingebjørg og Boye Wangensteen (red.), 2.utg., Oslo: Universitetsforlaget, 1997.

Study Group on a European Civil Code, Draft Common Frame of Reference (DCFR), 2009. The Nordic Association of Maritime Insurers, Norsk sjøforsikringsplan (NSFP), 1996 (Versjon 2010). 